This report has been reproduced directly from the best available copy.

Available to DOE and DOE contractors from the Office of Scientific and Technical Information, P.O. Box 62, Oak Ridge, TN 37831; prices available from (615) 576-8401, FTS 626-8401.

Available to the public from the National Tecinical Information Service, U.S. Department of Commerce, 5285 Port Royal Rd., Springfield, VA 22161.

NTIS price codes--Printed Copy: AO7 Microfiche AO1

This report was prepared as an account of work sponsored by an agency of the United States Government. Neither the Uniliad States Government nor any agency thereof, nor any of their ernployees, makes any warranty, express or implied, or assumes any legal liability or responsibility for the accuracy, completeness, or usefulnass of any information, apparatus, product, or process disclosed, or represents that its use would not infringe privately owned rights. Reference herein to any specific commercial product, process, or service by trade name, trademark, manufacturer, or otherwise, does not necessarily constitute or imply its endorsement, recommenidation, or favoring by the United States Government or any agency thereof. The views and opinions of authors expressind herein do not necessarily state or reflect those of the United States Government or any agency thereof. 


\title{
EVALUATION OF FISH KILLS DURING NOVEMBER 1986 AND JULY 1987 IN UPPER EAST FORK POPLAR CREEK NEAR THE Y-12 PLANT
}

\author{
M. G. Ryon \\ J. M. Loar \\ G. R. Southworth \\ A. J. Stewart \\ S. M. Adams \\ L. A. Kszos
}

Environmental Sciences Division Publication No. 3514

Date Published - September 1990

\footnotetext{
Prepared by the OAK RIDGE NATIONAL LABORATORY

Oak Ridge, Tennessee 37831-6285 operated by MARTIN MARIETTA ENERGY SYSTEMS, INC. for the

U.S. DEPARTMENT OF ENERGY under contract DE-AC05-84OR21400
} 
LIST OF FIGURES . . . . . . . . . . . . . . . . . . . . . . . . . vii

LIST OF TABLES . . . . . . . . . . . . . . . . . . . . . ix

ACKNOWLEDGMENTS . . . . . . . . . . . . . . . . . . . . . . . . . Xi

ABSTRACT ........................ . . xili

1. BACKGROUND INFORMATION . . . . . . . . . . . . . . . . . . 1

1.1 NOVEMBER 1986 FISH KILL . . . . . . . . . . . . . . . . 1

1.2 JULY 1987 FISH KILL . . . . . . . . . . . . . . . . . . 4

1.3 SITE DESCRIPTION . . . . . . . . . . . . . . . 5

2. INVESTIGATIVE STUDIES . . . . . . . . . . . . . . . . . . . . 8

2.1 NOVEMBER 1986 FISH KILL . . . . . . . . . . . . . . . . 8

2.2 JULY 1987 FISH KILI . . . . . . . . . . . . . . . . . . . . 16

3. EVALUATION OF POTENTIAL CAUSES OF THE FISH

KILI (EPIZOOTIC) . . . . . . . . . . . . . . . . . . . . . . 22

3.1 OVERCROWDING . . . . . . . . . . . . . . . . . . . . . . 22

3.2 TEMPERATURE . . . . . . . . . . . . . . . . . . . . . . 26

3.3 ELECTROSHOCKING . . . . . . . . . . . . . . . . . . 27

3.4 POLllutaNTS . . . . . . . . . . . . . . . . . . . . . . . 31

3.4.1 MERCURY . . . . . . . . . . . . . . . . . . . . . 31

3.4.2 OTHER INORGANICS . . . . . . . . . . . . . . . . 33

3.4.3 ORGANICS . . . . . . . . . . . . . . . . . . . . 33

3.5 CUMULATIVE STRESS . . . . . . . . . . . . . . . . . . . 35

3.6 ROLE OF THE PATHOGEN AND NEW HOPE POND . . . . . . . . . 35

4. ENVIRONMENTAL CONSEQUENCES OF THE EPIZOOTIC . . . . . . . . . 37

5. INTERAGENCY INTERACTIONS . . . . . . . . . . . . . . . . . . 38

6. CONCLUSIONS/RECOMMENDATIONS .... . . . . . . . . . . . . . 44

7. REFERENCES . . . . . . . . . . . . . . . . . . . . . . 46

APPENDIX A MEMO FROM L. A. KSZOS, ENVIRONMENTAL SCIENCES DIVISION (ORNL), TO J. M. LOAR, ENVIRONMENTAL SCIENCES DIVISION (ORNL), DESCRIBING RESULTS OF TOXICITY TESTS

ON SEWER-LINE SLUDGE, USING STONEROLLERS

(Campostoma anomalum) 
APPENDIX B L.ETTER FROM C. P. CARLSIJN, U.S. FISH AND WILDLIFE SERVICE, TO S. M. ADAMS, ENVIRONMENTAL SCIENCES DIVISION (ORNL), DESCRIBING RESULTS OF THE LABORATORY TESTS ON STONEROLLERS (Campostoma anomalum) . . . . . . . . B-1

APPENDIX C WATER QUALITY PARAMETERS MEASURED DURING THE AMBIENT TOXICITY TESTS ON WATER FROM EAST FORK POPLAR CREEK AEOVE AND BELOW NEW HOPE POND, JANUARY - JULY 1987 . . . . . . . . . . . . . . . . . . C-1

APPENDIX D CONCENTRATION OF TOTAL MERCURY IN GRAB SAMPLES COLLECTEDAT NEW HOPE POND FROM OCTOBER 27 THROUGH DECEMBER 15, 1986, AND FROM JUNE 1 THROUGH JULY 20, 1987 . . . . . . . . D-1

APPENDIX E CONCENTRATIONS OF INORGANIC CHEMICALS IN THE GUT CONTENTS OF STONEROLLERS (Campos toma anoma lum) COLLECTED ON NOVEMBER 1986 . . . . . . . . . . . . E-1

APPENDIX F MERCURY CONTENTS OF PERIPHYTON, FEBRUARY 10,1987 . . . . . . . . . . . . . . . . . . F-1

APPENDIX G CONCENTRATIONS OF INORGANIC COMPOUNDS IN COMPOSITE SAMPLES OF WATER COLLECTED AT THE OUTFALL OF NEW HOPE POND DURING 7-d TOXICITY TESTS AT NEW HOPE POND ON OCTOBER 7-14, NOVEMBER 4-11, AND NOVEMBER $18-25,1986, \ldots . . . .6 \mathrm{G}-1$

APPENDIX H LIST OF INORGANIC CONSTITUENTS MEASURED DAILY IN COMPOSITE SAMPLES COLLECTED FROM THE INLET AND OUTLET OF NEW HOPE POND, OCTOBER 1 THROUGH DECEMBER 15, 1986......... H-1

APPENDIX I CONCENTRATIONS OF INORGANIC COMPOUNDS IN COMPOSITE WATER COLLECTED AT THE OUTFALL OF NEW HOPE POND DURING JUNE 1 TO JULY 2 AND JULY 7 TO JULY 20,1987 . . . . . . . . . . . . . . I-1

APPENDIX J LIST OF INORGANIC AND ORGANIC CHEMICALS MEASURED DAILY IN COMPOSITE WATER SAMPLES COLLECTED AT THE OUTFALL OF NEW HOPE POND DURING 7-d TOXICITY TESTS ON DECEMBER 2-8 AND DECEMBER 9-15, 1986 . . . . . . . . . . . . . . J-1 
APPENDIX $K$ LIST OF ORGANIC CHEMICALS MEASURED IN DAILY COMPOSITE WATER SAMPLES COLLECTED AT THE OUTFALL OF NEW HOPE POND DURING 7-d TOXICITY TESTS ON OCTOBER 7-14, NOVEMBER 3-11, AND NOVFMBER $18-25,1986$

APPENDIX I LIST OF ORGANIC CHEMICALS MEASURED IN DAILY COMPOSITE WATER SAMPLES COLLECTED AT THE OUTFALL AND INLET OF NEW HOPE PON $\triangle$ DURING 50-d TOXICITY TESTS ON JUNE 1 TO JULY 20,1987 . . . L-1 
Map of upper East Fork Poplar Creek, Indicating area of fish kills and sites surveyed. . . . . . . .

2

Effect of bacteria and fish density on the mortality rate (mean number of days required to kill the population in eacii tank) of stonerollers obtained from an unpolluted stream. . .

3

Dally mean temperatures in East Fork Poplar Creek and Brushy Fork prior to fish kills on November 21, 1986, and July 9, 1987 
Number of dead and dying fish collected over a 1.4-km reach of East Fork Poplar Creek downstream of New Hope Pond during November/December 1986

Number of dead and dying fish collected over a $1.4-\mathrm{km}$ reach of East Fork Poplar Creek downstream of New Hope Pond during July 1987 . . . .

Concentrations of ICAP metals in one grab sample per site collected the morning of November 21, 1986, at the outfall of New Hope Pond and four sites downstream in the jity of Oak Ridge. . . . . . . . . . . . . . . . .

Water quality parameters and toxicity of water from the outfall of New Hope Pond for various $7-d$ consecutive periods in October, November, and December 1986 . . . . . . . . . . . . . . . . .

Reproduction of Ceriodaphnia in water from the outfall of New Hope Pond and in control water in 7-d static-renewal tests conducted in June-July, August, October, and November, 1986

Survival and reproduction of Ceriodaphnia and survival and gxowth of fathead minnow larvae reared for 7-d perlods in water from the inlet and outfall of New Hope Pond

Comparison of $24-h$ composite vs grab samples taken from the inlet and outfall of New Hope Pond during July $9-15,1987$

Estimated size of the stoneroller population and the total fish population in a 116-m reach of East Fork Poplar Creek. . . . . . . .

Electroshocking activities in upper East Fork Poplar Creek below New Hope Pond during the period associated with the fish kills........ 
Table

Total mercury levels in intestine, muscle, and

Chronological sequence of interactions between varlous parties responsible for the investigation of the fish epizootic that occurred in November 1986 in East Fork Poplar

Creek below New Hope Pond . . . . . . . . . . . . . .

Chronological sequence of interactions between various parties responsible for the investigation of the fish eplzootic that occurred in July 1987 in East Fork Poplar Creek below New Hope Pond . . . . . . . . . . . . . . 


\section{ACKNOWLEDGMENTS}

We would like to thank D. K. Cox, W. M. Harris, W. C. Kyker, C. M. Morrissey, and L. M. Stubbs for their assistance with the field work. Substantial support in the laboratory was provided by

K. L. Sheppard, K. Seeley, R. D. Balley, G. J. Haynes, and L. F. Wicker. We thank N. M. Ferguson, B. C. Grant, T. G. Scott, J. H. Stewart, and other staff members in the ORNL Analytical Chemistry Division for sample analysis. The inftial manuscript preparation by $V$. Ewing and technical review by G. F. Cada and B. C. Harvey are also greatly appreciated.

This work was funded by the Department of Environmental Management of the Health, Safety, Environment, and Accountability Division, Oak Ridge Y-12 Plant. The Y-12 Plant and Oak Ridge National Laboratory are operated by Martin Marietta Energy System, Inc., under contract DE-AC05-840R21400 with the U.S. Department of Energy. 


\section{ABSTRACT}

RYON, M. G., J. M. LOAR, G. R. SOUTHWORTH, A. J. STEWART, S. M. ADAMS, and L. A. KSZOS. 1990. Evaluation of fish kills during November 1986 and July 1987 in upper East Fork Poplar Creek near the Y-12 Plant. ORNL/TM-11578. Oak Ridge National Laboratory, Oak Ridge, Tennessee., $128 \mathrm{pp}$.

The Environmental Sciences Division (ESD) Irvestigated two fish kills that occurred on November 21, 1986, and July 9, 1987, in upper East Fork Poplar Creek at the outfall of New Hope Pond (NHP) below the Oak Ridge Y-12 Plant. A $5.5-\mathrm{km}$ area downstream of NHP was initially surveyed following each $\mathrm{kill}$, and a $1.6 \mathrm{~km}$ reach was routinely surveyed for an additional 23 to $25 \mathrm{~d}$. The fish kills were limited primarily to the stoneroller (Campostoma anomalum); 1148 fish died in the first kill, and $747 \mathrm{fish}$, in the second. Affected fish showed extensive scale loss, fin rot, and hemorrhaging from the gills, fins, and anus. Numerous unaffected fish were observed in the survey areas during and following both kills.

Investigative procedures included sampling of water at the inlet and outfall of NHP for water quality, examination of operating procedures at the Y-12 Plant and in the biomonitoring program that may have adversely affected the fish populations, review of results of concurrent ambient toxicity tests of the inlet and outfall water of NHP, autopsy investigations of the cause of death of the stonerollers, and laboratory experimentation to evaluate potential causes. This investigation involved ESD staff, Y-12 Plant staff, and a disease specialist with the U.S. Fish and Wildilfe Service and continued for several months following the kills.

The investigations revealed that the cause of death was bacterial hemorrhagic septicemia caused by Aeromonas hydrophila, which is a stress-mediated disease. The specific stressor responsible for the outbreak of the disease was not identifled. Several possible stresses were findicated, including elevated concentrations of mercury and 
chlorine, excessive electroshocking activity, and elevated levels of the pathogen. Cumulative stress due to the combination of several factors was also suggested. Elevated temperatures and overcrowding may have enhanced the spread of the epizootic but were not the primary causes. The impact on the stoneroller population below NHP was not ecologically significant. 


\section{BACKGROUND INFORMATION}

On Friday, November 21, 1986, at 9:20 a.m., J. M. Loar of the Environmental Sciences Division (ESD) at Oak Ridge National Laboratory, received a call from J. D. Gass of the Health, Safety, Environment, and Accountability Division at the Y-12 Plant concerning dead fish in East Fork Poplar Creek (EFPC) below the outfall of New Hope Pond (NHP). An investigation of the kill was initiated immediately and continued for approximately 3 weeks. On Thursday, July 9, 1987, at approximately 12:00 p.m., M. G. Ryon observed moribund fish below NHP during routine sampling. The sampling was promptly halted, and a survey of the fish kill was initiated. A summary of the findings of these investigations is presented herein.

\subsection{NOVEMBER 1986 FISH KILL}

Following notification of the kill on November 21, ESD staff examined the fish below NHP outfall and conducted a reconnaissance of the upper reaches of EFPC to determine the extent of the kill. The reconnaissance involved crews walking upstream through each site collecting and, later, counting all dead and dying fish and aquatic vertebrates. A $5.5-\mathrm{kn}$ reach of EFPC below NHP was surveyed that morning. Observations were made at the five bridges between East Fork Poplar Creek kilometer (EFK) 18.2 (at the intersection of Jefferson Avenue and Oak Ridge Turnpike) and EFK 2.2.3 (behind Dean Stallings Ford), where the first dead and dying fish were observed (Fig. 1). No dead fish were found in approximately 100-m reaches of stream near the bridges downstream of EFK 22.3. Areas near these bridges were also checked on five other days (November 22, 24-26, and December 1), and only one dead fish was found (on December 1 at the upper Tulsa Avenue bridge at EFK $21.4,0.9 \mathrm{~km}$ below

Dean Stallings Ford).

Systematic surveys of a $1.4-\mathrm{km}$ reach of EFPC between EFK 22.3 and NHP were conducted between November 21 and December 15 (Table 1). All dead or dying fish were collected by a one- or two-person crew from ESD. On November 21-23, Wayne Schacher, Anderson County vildlife Officer of 


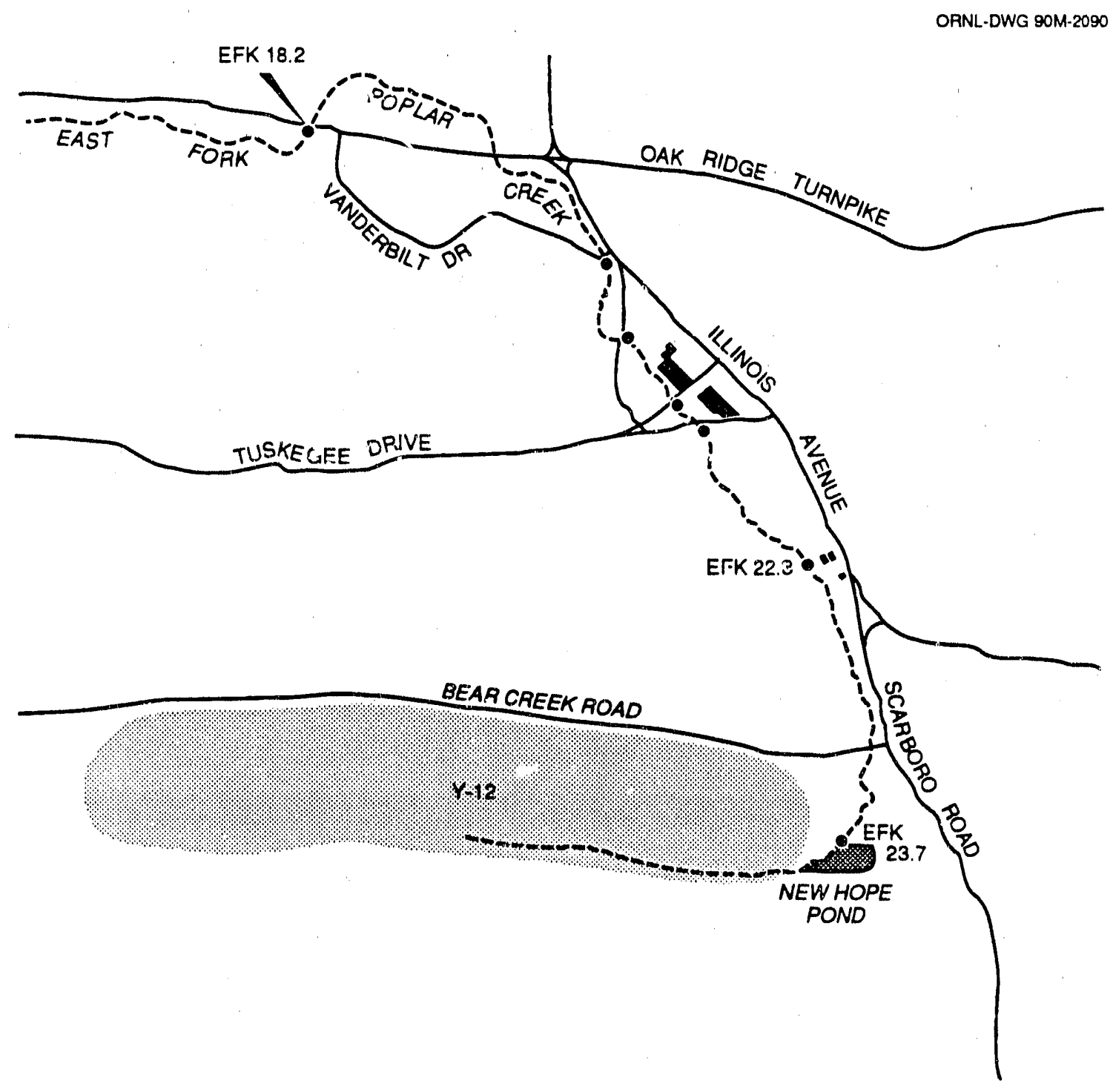

Fig. 1. Map of upper East Fork Poplar Creek Indicating area of fish kilis and sites surveyed. EFK = East Fork kilometer. 
Table 1. Number of dead and dying fish collected over a 1.4- km reach of East Fork Poplar Creek downstream of New Hope Pond during November/December 1986

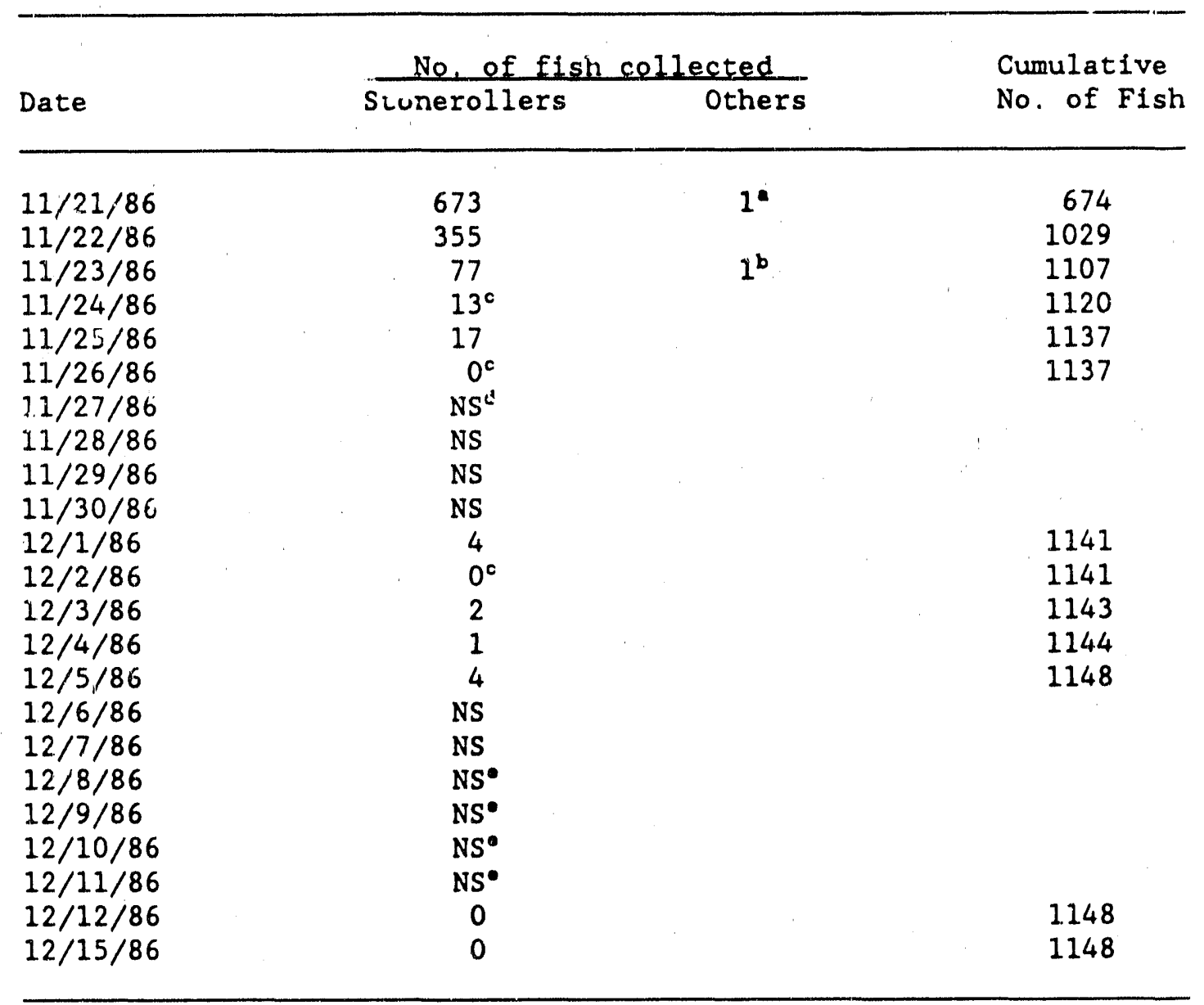

alacknose dace (Rhinishthys atratulus).

bStriped shriner (Notropis chrysocephalus).

cActual number of dead fish was probably underestimated because of turbid water.

dNS - no survey vas conducted.

"Survey was not conducted because of high flows and turbidity. 
the Tennessee Wildlife Resources Agency (TWRA) assisted the ESD crew in surveying. To meet the reporting requirements of the TWRA, fish were identified by spicies and categorized by 2 -in. size classes. Except for the first day (November 21), all fish were also categorized by post-mortem changes: (1) no loss of color, indicating recent death (less than a few hours); (2) pale color, rigid body without signs of decomposition (died within pest $24 \mathrm{~h}$ ); and (3) decomposed, with only fragments of the skeleton present in worse cases (died prior to past $24 \mathrm{~b})$. Fish in the latter category were added to the counts of fish in the first two categories for the preceding day to arrive at the total number killed per day as shown in Table 1.

Based on these surveys, the November 1986 fish kill can be described as follows.

1. A total of 1148 dead or dying fish were collected from EFPC, and all (99.88), but two individuals were stonerollers, Campostoma anomalum,

2. Most of the fish collected were hemorrhaging (bleeding) from the gills, pectoral fins, pelvic fins, and/or anus,

3. The kill began eariy in the morning of November 21 and continued over a 2-week period through at least December 5; no evidence, such as decomposed remains, was fo'nd to indicate that fish died before November 21 ,

4. Ninety percent of the fish died on the first $2 d$,

5. Numerous live fish, including stonerollers, were observed behaving normally throughout the $1.4 \mathrm{~km}$ reach of EFPC below NHP during the November/December survey period,

6. Dead crayfish were also found in relatively low numbers; a total of 26 was found for the $24-d$ period, a maximum of 13 on November 23.

\subsection{JULY 1987 FISH KILI}

Immediately following discovery of the July $9 \mathrm{kill}$, ESD staif conducted a survey for dead or dying fish in EFPC between NHP and Bear Creek Road and then alerted the appropriate Y-12 Plant staff and the ESD Aquatis Toxicology group. Later that day, checks at the five downstream bridges and a survey of the upper $1.4 \mathrm{~km}$ of EFPC were done in 
the same manner as in November 1986. Systematic surveys of this upper section of EFPC were continued over the period of July 9 to July 31

(Table 2). Checks of the downstream bridges were made on $6 \mathrm{~d}$ (July 10-12, 16-17, and 21), and only one dead Eish, a striped shiner, was found (on July 16 at the upper Tulsa Avenue bridge). Because of rainfall with associated turbidity, mortality was probably underesifimated on July 12. Also, a blockiset was used at the lower end of the survey reach from July 15 through 17, which increased the number of dead fish recovered on those days.

Based on these suryeys, the July 1987 fish kill can be described as follows.

1. A total of 747 dead or dying fish were collected from EFPC, and all but 18 were stonerollers (97.68),

2. Most of the fish were hemorrhaging, showed extensive scale loss or fin rot, or were swimming erratically in a spiral motion; fewer fish showed hemorrhaging and more showed fin rot than during the November $1986 \mathrm{kill}$,

3. The kill began before its discovery on July 9, as indicated by decomposed fish, and the mortality pattern was extended over a 3-week period,

4. Forty-eight percent of the fish died during the first week; 96 died within the first $10 \mathrm{~d}$,

5. Numerous live fish, including stonerollers, were observed behaving normally throughout the $1.4-\mathrm{km}$ reach,

6. Low numbers of dead crayfish were also found; a total of 40 were found for the 23-d period, a maximum of 9 on July 15 ,

7. Predation on dead or dying fish by kingfishers (Megaceryle alcyon), great whlte herons (Ardea herodias), and green-back herons (Butorides striatus) was observed during the entire July 1987 fish kill (in contrast to the November 1986 fish kill).

\subsection{SITE DESCRIPTION}

The 1.4-km area in which the fish kills occurred is part of upper EFPC below NHP and east of the Y-12 Plant (Fig. 1). The headwaters of EFPC consist of springs that originate on the 
Table 2. Number of dead and dying fish collected over a

$1.4-\mathrm{km}$ reach of East Fork Poplar Creek downstream of New Hope Pond durlng July 1987

\begin{tabular}{|c|c|c|c|c|}
\hline \multirow[b]{2}{*}{ Date } & & \multicolumn{2}{|c|}{ No, of fish collected } & Cumulative \\
\hline & & tonerollers & Others & No. of Fish \\
\hline $7 / 8 / 87$ (and & earlier) & 24 & & 24 \\
\hline $7 / 9 / 87$ & & 55 & $1^{b}$ & 80 \\
\hline $7 / 10 / 87$ & & 41 & & 121 \\
\hline $7 / 11 / 87$ & & 94 & & 215 \\
\hline $7 / 12 / 87$ & & $14^{c}$ & $1^{d}$ & 230 \\
\hline $7 / 13 / 87$ & & 32 & & 262 \\
\hline $7 / 14 / 87$ & & 93 & $2^{\bullet}$ & 357 \\
\hline $7 / 15 / 87$ & & 67 & $1^{f}$ & 425 \\
\hline $7 / 16 / 87$ & & 216 & $8^{8}$ & 649 \\
\hline $7 / 17 / 87$ & & 63 & $3^{\mathrm{h}}$ & 715 \\
\hline $7 / 18 / 87$ & & 5 & & 720 \\
\hline $7 / 19 / 87$ & & 2 & & 722 \\
\hline $7 / 20 / 87$ & & 4 & & 726 \\
\hline $7 / 21 / 87$ & & 4 & & 730 \\
\hline $7 / 22 / 87$ & & 4 & $1^{1}$ & 735 \\
\hline $7 / 23 / 87$ & & 4 & $1^{d}$ & 740 \\
\hline $7 / 24 / 87$ & & 6 & & . 746 \\
\hline $7 / 25 / 87$ & & NS $^{\mathrm{J}}$ & & \\
\hline $7 / 26 / 87$ & & NS & & \\
\hline $7 / 27 / 87$ & & 1 & & 747 \\
\hline $7 / 28 / 87$ & & NS & & \\
\hline $7 / 29 / 87$ & & 0 & & 747 \\
\hline $7 / 30 / 87$ & & NS & & \\
\hline $7 / 31 / 87$ & & 0 & & 747 \\
\hline
\end{tabular}

aish found on July 9 that were decomposed and died prior to past $24 \mathrm{~h}$.

bedbreast sunfish (Lepomis auritus).

"Water was high and turbid after heavy rainfall.

dBluegill sunfish (Lepomis macrochirus).

- One white sucker (Catostomus commersoni) and one mosquito fish (Gambusia affinis).

${ }^{2}$ Creek chub (Semotilus atromaculatus).

sone creek club, four mosquitofish, two blacknose dace (Rhinichthys atratulus), and one striped shriner (Notropis chrysocephalus) (at upper Tulsa Avenue bridge).

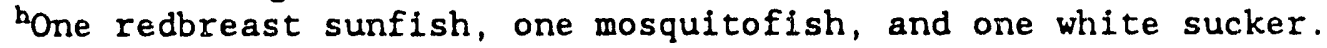

'White sucker.

JNS - no survey made. 
northwest slope of Chestnut Ridge. The stream is contained in culverts through much of the west end of the $\mathrm{Y}-12$ Plant before entering a riprap channel that is approximately $2.4 \mathrm{~m}$ wide and $2.6 \mathrm{~m}$ high (Kasten 1986). EFPC receives effluents from numerous outlets in this $1.5 \mathrm{~km}$ section within the boundaries of the Y-12 Plant. Included in the discharges are cooling water and cooling-tower blowdown (648 of discharge volume), process wastewater (328), coal-yard runoff, and storm drainage. The process wastewaters include effluents from wastetreatment facilities, photographic laboratories, fire-fighter training zunes, plating operations, miscellaneous laboratories, and chemical preparation and make-up areas (Loar 1988).

At the time of the fish kills, EFPC entered NHP, a 2.2-ha retention basin designed to equalize $\mathrm{pH}$ of the plant effluents (Pritz and Sanders 1982). Although the pond has now been drained, filled, and capped, it was used for neutralization, sediment retention, and spill control prior to November 1988. After passing over a concrete weir at the outfall of the pond, EFPC flowed $23.7 \mathrm{~km}$ to its confluence with Poplar Creek.

The fish kills occurred in the $1.4 \mathrm{~km}$ reach of EFPC from the NHP outfall to below Bear Creek Road near Dean Stallings Ford, about $300 \mathrm{~m}$ downstream of the DOE Oak Ridge Reservation (ORR) boundary. The average width of the stream in this reach is $4.8 \mathrm{~m}$, and the average depth is $27 \mathrm{~cm}$ (Loar 1988). Substrate is typically gravel and cobble interspersed with rough bedrock outcrops and occasional patches of algae or Potamogeton sp. The section immediately below the NHP outfall and on either side of Bear Creek Road is lined with rip-rap banks, but the remaining sections have natural clay banks, often with undercut areas. Vegetated cover above Bear Creek Road is limited to meadow grasses and large deciduous trees (canopy cover of 0 to 908). Below the road, a more consistently enclosed canopy exists with heavily wooded banks. No obvious ecological impacts on EFPC from commercial development are evident in the reach below the ORR boundary. 


\section{INVESTIGATIVE STUDIES}

\subsection{NOVEMBER 1986 FISH KILI}

Intensive sampling of water quality at the outfall of NHP and downstream was initiated by Y-12 Plant staff immediately after notification of the November fish kill (Table 3). The preliminary data were reviewed by representatives of the U.S. Department of Energy (DOE), ESD, and the Y-12 Plant on November 24. Elevated levels of total mercury $(\mathrm{Hg})$ of 30 to $40 \mathrm{ppb}$ were recorded on November 19, 20, and 21 by the on-line mercury analyzer at the outfall of NHP; normal concentrations range from 1 to $3 \mathrm{ppb}$. Levels of $\mathrm{Hg}$ in the November 21 gxab samples had declined to a more typical range (2 to $9 \mathrm{ppb}$, Table 1 ). Some of the peaks coincided with the removal of a downstream plug in the storm.sewer line immediately south of Bullding 9201-4. This long, mercury-contaminated line was being cleaned as part of the remedial action program to reduce mercury in plant effluents. Removal of the plug caused the release of approximately 100 to $200 \mathrm{~L}$ of water. Cleaning operations were terminated on November 21 but resumed again on December 1, following a second meeting held that morning between staff from DOE, ESD, and the Y-12 Plant. Criteria thai were considered in the decision to resume the cleaning operation included (1) knowledge of the pathogenic cause of fish death, (2) return of water quality in lise outfall of NHP to prekill conditions, (3) information indicating that either the kill was over or near termination, and (4) low turbidity in EFPC to permit monitoring of the fish populations in the stream after cleaning operations resumed.

To investigate the hypothesis that mercury releases at the Y-12 Plant were associated with the fish kill, Laboratory toxicity tests were conducted on November 25 on stonerollers collected from an uncontaminated region of white Oak Creek above ORNL (Appendix A). Sludge renoved from the contaminated sewer Ine and deposited in the northwest sludge basin was added to several aerated aquaria in the Aquatic Ecology Laboratory of ESD at approximate concentrations of 30,15 , and $0.5 \mathrm{~g}$ of sludge per liter. A control aquarium (without any type of sediment added) had a turbidity equivalent to that in the 


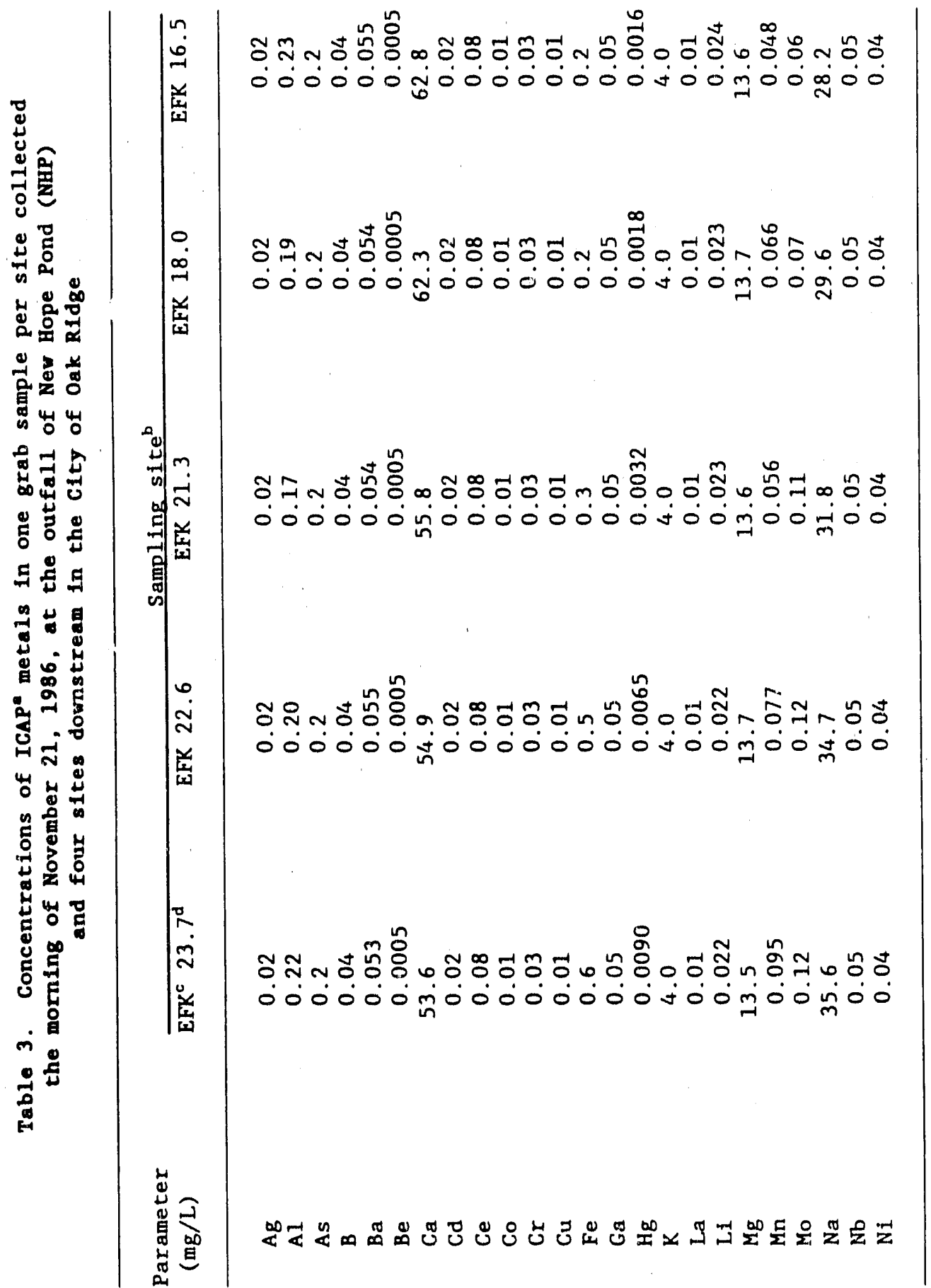




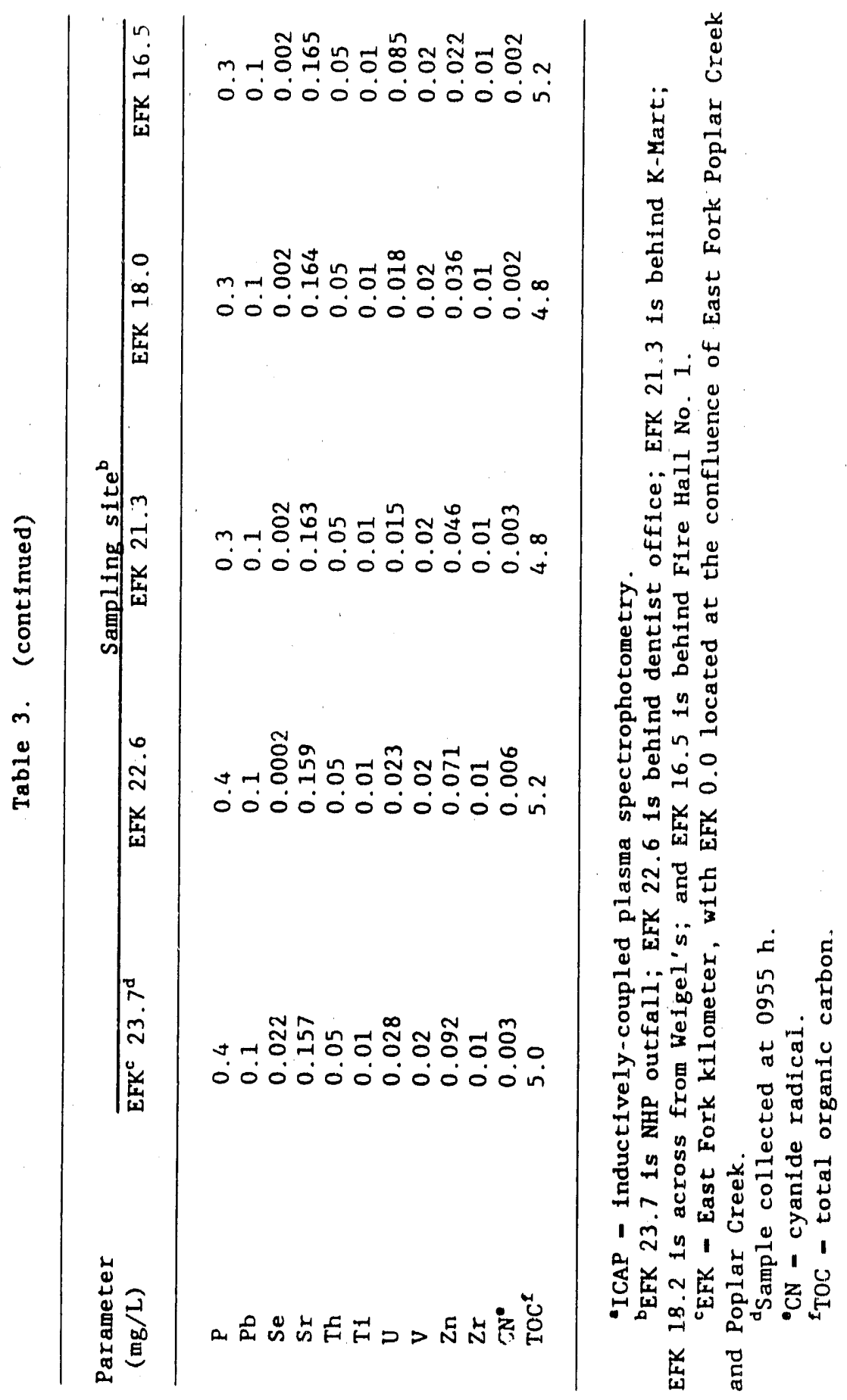


low-concentration aquarium ( $23 \mathrm{NTU}$ ), No measurements were made of actuel $\mathrm{Hg}$ concentrations in the aquaria. All $10 \mathrm{fish}$ at each of the two higher levels died within $67 \mathrm{~h} ; 3$ of 10 died at the lowest lavel after $111 \mathrm{~h}$. Although mortality was related to concentration, the fish probably died from the high turbidity (approximately $200 \mathrm{NTU}$ ) at the two higher concentrations. Fish dying in this test did not exhibit the same symptoms (e.g., hemorrhaging) observed in fish dying in EFPC, and observations of the gills of the fish that died in the high turbidity aquaria showed higher than normal secretions of mucus, a general indicator of gill irritation. Although the test results did not support the hypothesis that mercury-containing sludge discharged during the storm-sewer cleuning operations caused the fish kill, the results must be regarded as inconclusive because of the mortality observed in the test.

As part of the Y-12 Plant Blological Monitoring and Abatement Program (BMAP) for EFPC, as specified in Part III(C): Special Condition No. 7 of the National Pollutant Discharge Elimination System (NPDES) permit for the Y-12 Plant, ambient toxicity testing is routinely conducted at the outfall of NHP. Water from the outfall of NHP is testod for toxicity with a microcrustacean (Ceriodaphnia dubia/affinis) and fathead minnow larvae (Pimephales promelas). Each test lasts for $7 \mathrm{~d}$ and uses water samples composited daily over the test period. Portions of each dally sample of water are also analyzed for $\mathrm{pH}$, alkalinity, hardness, conductivity, and chlorine.

Water from the outfall of NHP was evaluated on a routine basis for toxicity once in October, twice in November, and once in December of 1986. The second test in November (November 18-24), spanned the period of the fish kill; the first (November 4-11) preceded the kill by $10 \mathrm{~d}$. The December 3-10 test followed the first reported $k 111$ by $12 \mathrm{~d}$. Water quality data acquired in conjunction with the toxicity tests and results of toxicity tests based on survival and growth of fathead minnow larvae are shown in Table 4. In the two November tests and one December test, survival of fathead minnow larvae reared in water from NHP was significantly $(p<0.05)$ reduced to $56.08,78.08$, and 72.08 , 


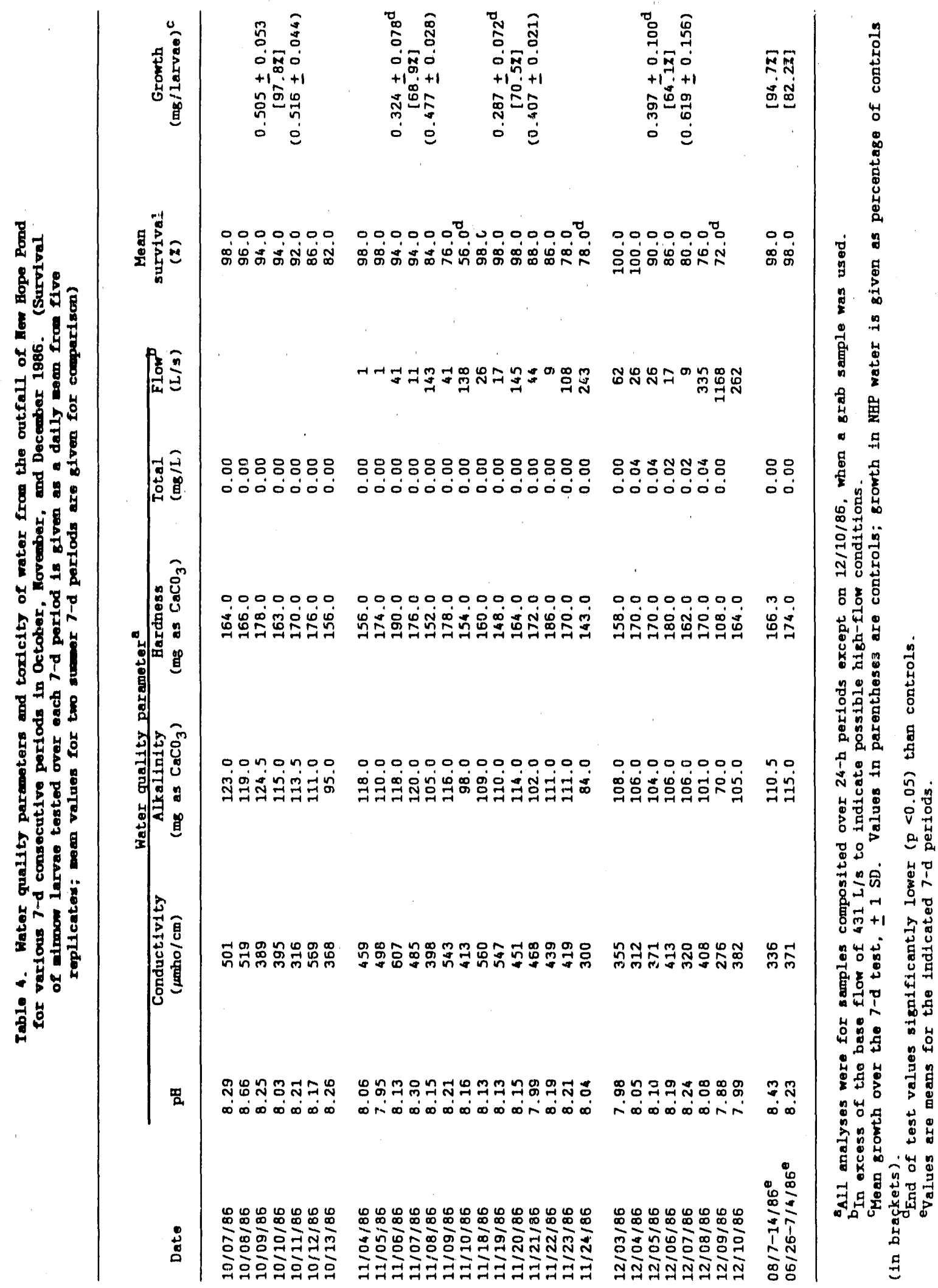


respectively; survival of the larvae in control water did not fall below 96.08 in any of these tests. In the same three tests, growth of the larvae in water from NHP was also significantly relluced to $68.98,70.58$, and 64.18, respectively, of growth of larvae in controls. In the test conducted in October and in tests during the summer of 1986 (Table 4), water from the pond did not show evidence of toxicity to fathead minnow larvae. In the same test periods, Cerlodaphnia reared in water from the outfall of NHP typically did about as well as, or in some cases somewhat better than, Ceriodaphnia reared in control (reconstituted hard) water (Table 5). The larval fish toxicity tests indicated the presence of an unknown toxic agent(s) in EFPC water during the time of the November fish kill.

Mercuric salts exhibit acute toxicity to freshwater fish in the 15 . to 500-ppb (as $\mathrm{Hg}$ ) range and to Daphnia magna at 5 to $13 \mathrm{ppb}$ (Cushman et a1. 1977). The lower limits of these ranges approximate levels of total $\mathrm{Hg}$ present in the NHP discharge during the week of November 17.

Toxiclty tests are performed using dissolved mercuric salts; however, Hg measurements made on ivHP discharge water represent the sum of dissolved and particle-associated $\mathrm{Hg}$. The latter form is relatively inert with respect to acute toxicity. Thus, assessing the toxicological significance of $\mathrm{Hg}$ in these waters requires reasonable estimates of the distribution of $\mathrm{Hg}$ between dissolved and particulate phases.

Studies of the phase distribution of $\mathrm{Hg}$ indicate that 10 to $25 \mathrm{z}$ of the total $\mathrm{Hg}$ in NHP discharge was in the dissolved form under summer temperature and flow conditions and at normal ( 1 to $3 \mathrm{ppb}$ ) $\mathrm{Hg}$ concentrations (Elwood et al. 1987). Abnormally high $\mathrm{Hg}$ levels at the outfall of NHP could result from (1) disturbance of mercury-contaminated sediments, which would increase the fraction of $\mathrm{Hg}$ that is particle-associated or (2) mobilization of dissolved $H_{G}$ by oxidants, etc., which would result in a higher-than-normal fraction of the $\mathrm{Hg}$ being in the dissolved state. A conservative assumption is that 508 of the $\mathrm{Hg}$ is in the dissolved form. Using this assumption, total $\mathrm{Hg}$ levels in excess of $25 \mathrm{ppb}$ in the NHP discharge would be at levels shown to be 
Table 5. Reproduction of Ceriodaphnia in water from the outfall

of New Hope Pond and in control (reconstituted hard) water

in 7-d static-reniwal tests conducted in June-July,

August, October, and November 1986 (Values are

the mean number of offspring ( $t 1$ SD) per

female surviving the full

7-d test perlod)

\begin{tabular}{|c|c|c|c|}
\hline $\begin{array}{c}\text { Test } \\
\text { period }\end{array}$ & $\begin{array}{l}\text { Offspring } \\
\text { per female }\end{array}$ & $\begin{array}{l}\text { Survival } \\
(8)\end{array}$ & $\begin{array}{c}\text { No. of } \\
\text { males excluded }\end{array}$ \\
\hline \multicolumn{4}{|l|}{$06 / 27-07 / 04 / 86$} \\
\hline Control ${ }^{b}$ & $15.8 \pm 3.6$ & 90 & 0 \\
\hline NHP water & $31.3 \pm 10.4$ & 90 & 1 \\
\hline \multicolumn{4}{|l|}{$08 / 07-14 / 86$} \\
\hline Control ${ }^{b}$ & $13.2 \pm 3.3$ & 100 & 0 \\
\hline NHP water ${ }^{b}$ & $14.8 \pm 2.6$ & 100 & 0 \\
\hline \multicolumn{4}{|l|}{$10 / 07-13 / 86$} \\
\hline Control ${ }^{\circ}$ & $24.7 \pm 3.6$ & 90 & 0 \\
\hline Control ${ }^{b}$ & $22.2 \pm 9.3$ & 100 & 1 \\
\hline NHP water ${ }^{\circ}$ & $22.6 \pm 4.1$ & 100 & 1 \\
\hline NHP water & $27 ? \pm 7.8$ & 100 & 1 \\
\hline NHP water ${ }^{b, d}$ & $28.4 \pm 10.1$ & 100 & 1 \\
\hline \multicolumn{4}{|l|}{$11 / 04-11 / 86$} \\
\hline Contro $1^{\circ}$ & $16.0 \pm 1.8$ & 100 & 1 \\
\hline NHP water ${ }^{\circ}$ & $16.2 \pm 5.1$ & 100 & 1 \\
\hline \multicolumn{4}{|l|}{$11 / 18-24 / 86$} \\
\hline Contro $1^{\circ}$ & $6.0 \pm 6.1$ & 90 & 0 \\
\hline Control ${ }^{b}$ & $19.6 \pm 6.0$ & 90 & 0 \\
\hline NHP water ${ }^{\circ}$ & $12.0 \pm 5.6$ & 80 & 0 \\
\hline \multicolumn{4}{|l|}{$12 / 03-10 / 86$} \\
\hline $\begin{array}{l}\text { No test done } \\
\text { test animals }\end{array}$ & cultures did & dee enoug & tes to use as \\
\hline
\end{tabular}

Male animals were included in computations of survival but were excluded from computations of fecundity.

${ }^{b}$ Animals fed digested trout-chow.

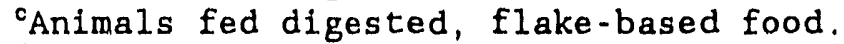

dWater filtered through $0.5 \mu \mathrm{m}$ pore-size glass-fiber filters before being tested. 
acutely toxic to channel catfish (Ictalurus punctatus), a microcrustacean (Daphnia magna), and the European dace (Phoxinus phoxinus) (Cushman et al. 1977). However, this level would be more than a factor of 10 below $\mathrm{Hg}$ concentrations acutely toxic to other species, such as rainbow trout (Oncorhynchus mykiss).

In addition to monitoring water quality, conducting toxicity tests, and evaluating the toxicological significance of elevatud mercury levels in the outfall of NHP, an investigation of other possible causes of death was initiated on November 24. Charles Carlson, a fish disease specialist with the U.S. Fish and Wildife Service (USFWS), was contacted by S. M. Adams for assistance with the investigation. Mr. Carlson visited ORNL on November 26 . He examined dead fish collected and frozen on November 21 and 25 and live fish collected on November 26. After the fish were examined for internal and external parasites, bacterial samples from the kidneys were obtained for culture and returned to the USFWS laboratory near Asheville, North Carolina. After the cultures had incubated for several days, Mr. Carlson called S. M. Adams with the results on Monday, December 1, prior to the meeting held that day; written confirmation of these results was obtained several days later (Appendix B). From these studies and other investigations (e.g., Pippy and Hare 1969; Wedemeyer et al. 1976), as well as individual conversations with Mr. Carlson by S. M. Adams and by J. M. Loar on December 1, the cause of death can be summarized as follows.

1. The direct cause of death was a bacterial hemorrhagic septicemia (BHS), also called motile aeromonad septicemia, an infectious bacterial disease often encountered in intensive fish culture systems,

2. The disease-causing organism (or pathogen) was Aeromonas hydrophila, which is normally present in most waters,

3. BHS is a stress-mediated disease (1.e., the host (fish) must interact with the pathogen in a stressful environment, which lowers the resistance of the fish to disease],

4. Environmental factors that promote epizootics of aeromonad/pseudomonad hemorrhagic septicemia include 
(a) pre-existing protozoan infections, (b) inadequate pond cleaning leading to increased bacterial loads in water, (c) increased particulate matter in water, (d) handling, (e) crowding, ( $f$ ) low oxygen, and $(g)$ chronic sublethal exposure to a variety of contaminants, including heavy metals; pesticides, and PCB (Wedemeyer and McLeay 1981),

5. No evidence of an association between the dead crayfish and BHS was collected.

\subsection{JULY 1987 FTSH KILL}

Following discovery of the July 1987 fish kill, ESD and Y-12 staff members were consulted concerning additional water quality sampling. Because water quality at the NHP inlet and outlet was already being monitored by both groups and the additional sampling of lower EFPC in November 1986 failed to yield significant new information (Table 3), additional water quality sampling was not conducted. However, as in November 1986, releases of elevated levels of mercury were monitored and were traced to cleaning of mercury-contaminated sewer lines. Because of these releases, mercury levels were also monftored more extensively in fish below NHP.

A review of mercury toxicity information published after the November 1986 fish kill (Etnier et al. 1987) confirmed the acute toxicity ranges of mercuric salts given in Sect. 2.1. No information was found on mercury toxicity to stonerollers or other fish found in EFPC.

Fortunately, ambient toxicity testing using the microcrustacean Ceriodaphnia dubia/affinis and the fathead minnow Pimephales promelas was conducted on NHP outfall water at the time of the fish kill. Using the methods described in Sect. 2.1, water from the inlet and outfall of NHP was tested at least once a month from January through July 1987 (Table 6). The results indicated that Ceriodaphnia and/or fathead minnow larvae occasionally showed effects of toxicity but only during the week of July 9-16 did both demonstrate effects from the inlet and/or outfall samples. In fact, more-severe effects were noted at the outfall, suggesting additional toxic inputs from NHP. These effects 


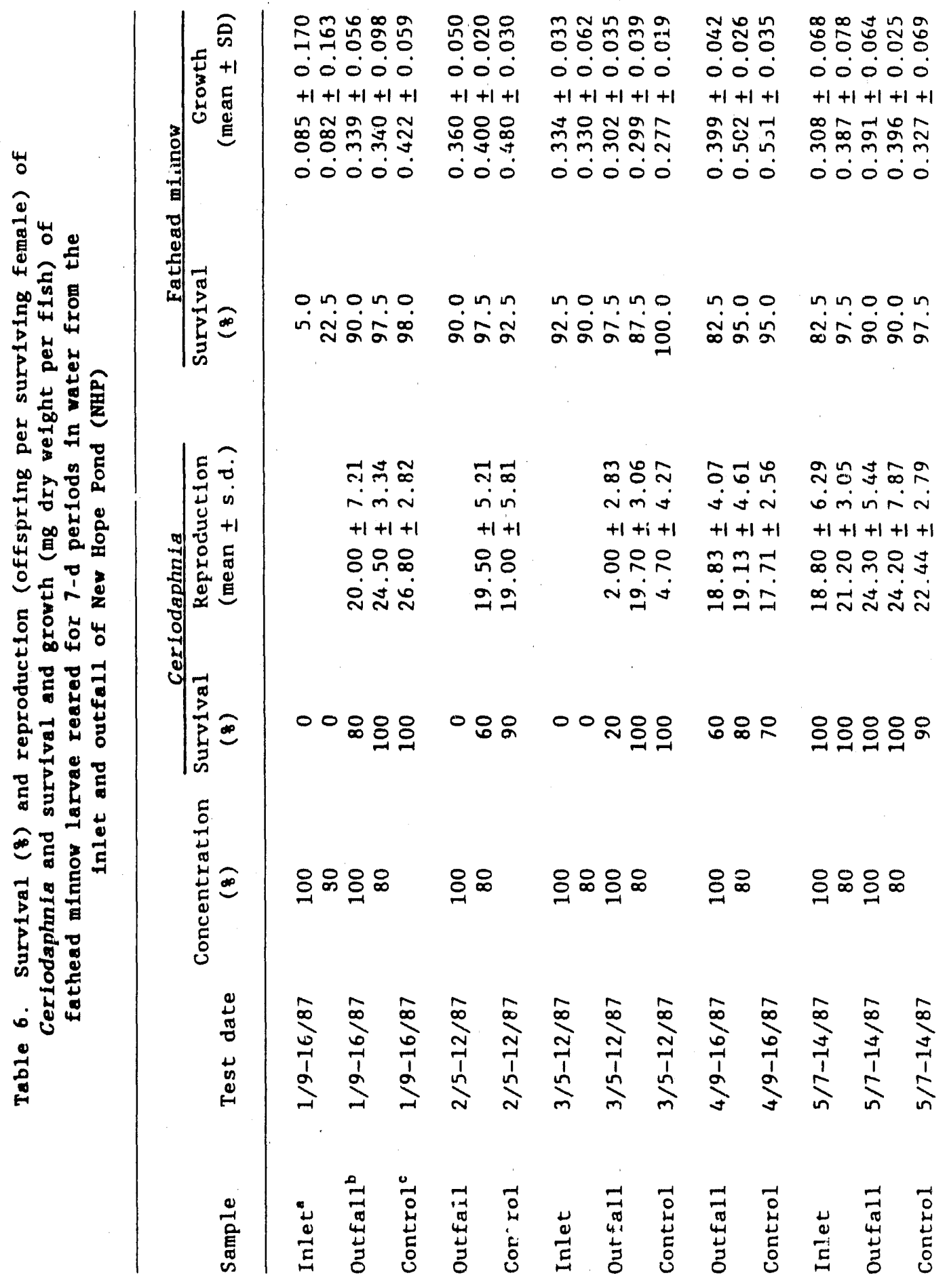




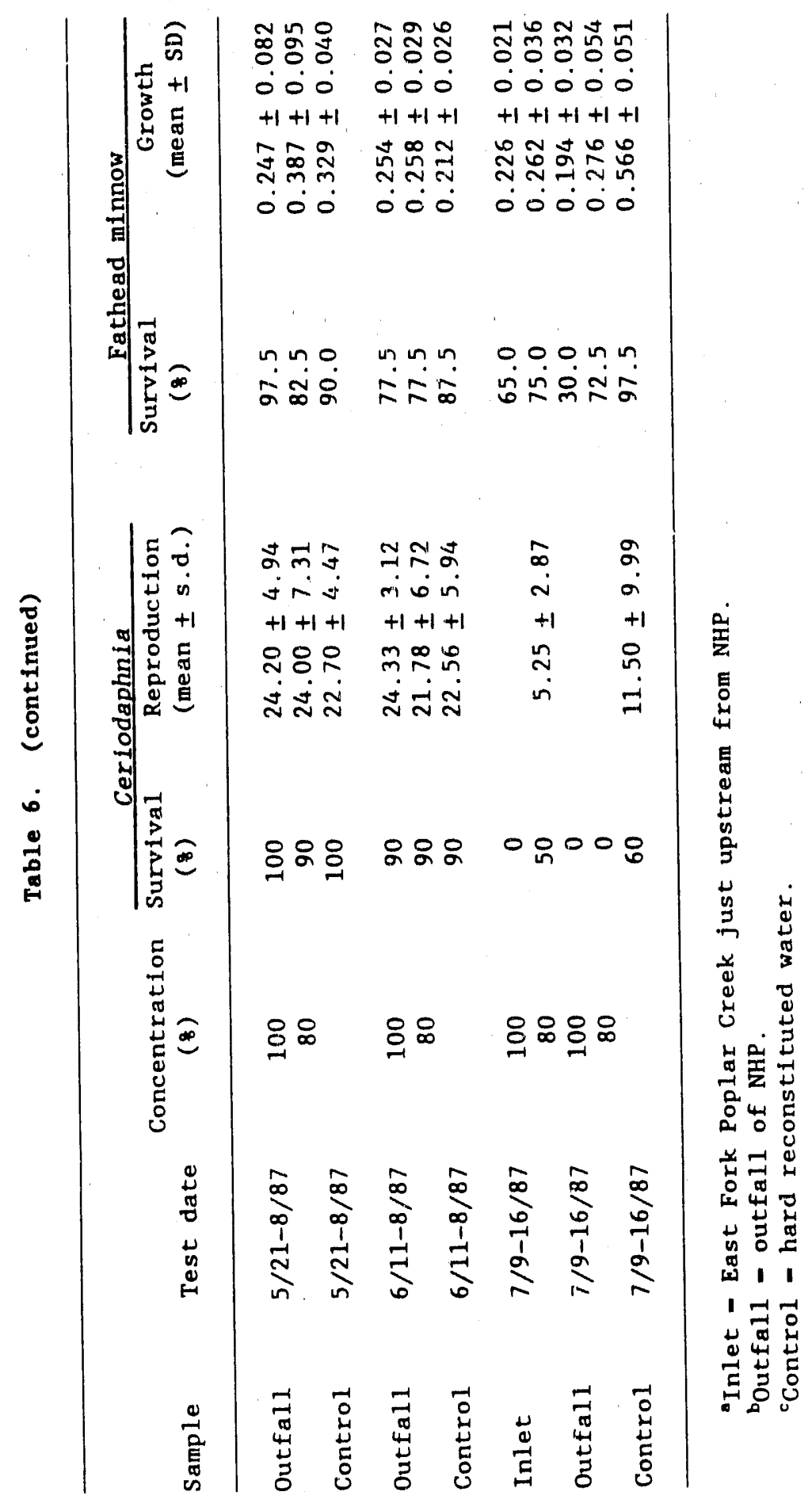


included decreased survival of Ceriodaphnia and fathead minnow larvae, decreased reproduction of Ceriodaphnia, and reduced growth of fathead minnow larvae. All significant effects were noted at 1008 and $80 z$ concentrations, with a corresponding decrease in the magnitude of the effect with decreasing concentration.

A review of water quality data collected concurrently with the july 9-16 toxicity test indicated that concentrations of residual chlorine were slightly elevated but decreased after passage through NHP (Table 7). Water quality data collected during the toxicity tests in 1987 are given in Appendix C.

In addition to these investigations, kidney smears were taken from dead or dying fish to confirm the presence of the bacteria Aeromonas hydrophila. These smears were sent to Charles Carlson of the USFWS, who confirmed that the bacteria were indeed present. Thus, the cause of death in the July $1987 \mathrm{kill}$. The same as that in the November $1986 \mathrm{fish}$ kill. The summary given in Sect. 2.1 accurately describes both incidents. 


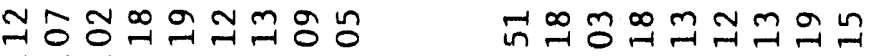
000000000 000000000

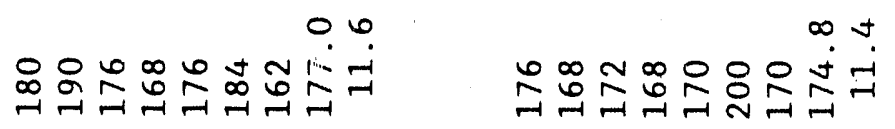

0000000 n 0.1

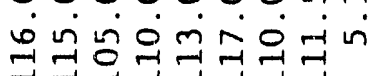

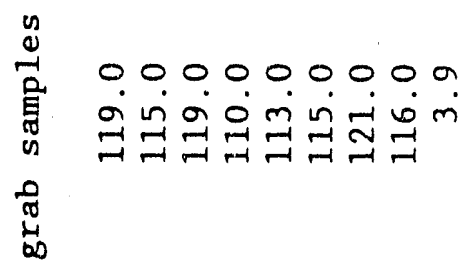

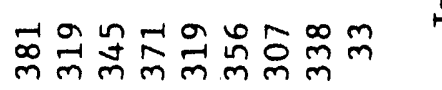

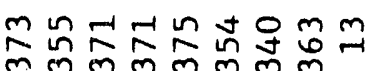

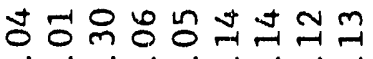

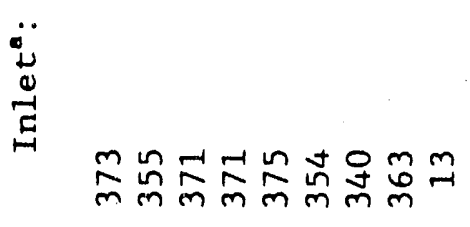

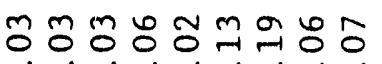
$\infty \infty \infty \infty \infty \infty \infty \infty$
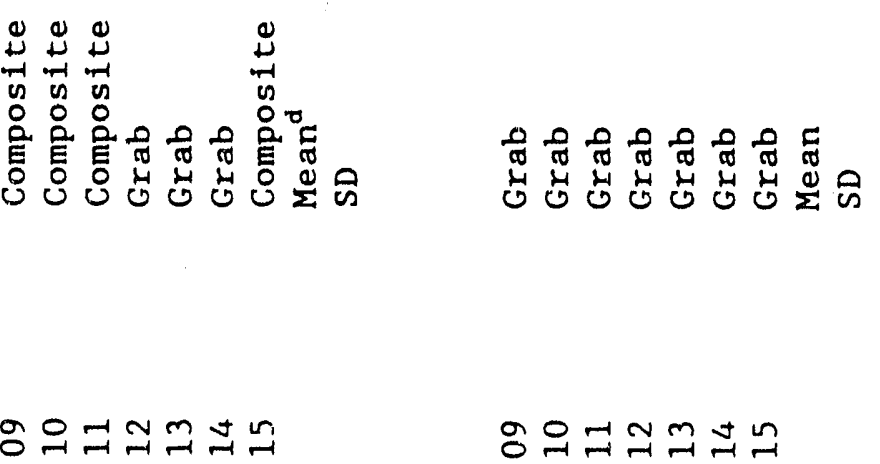


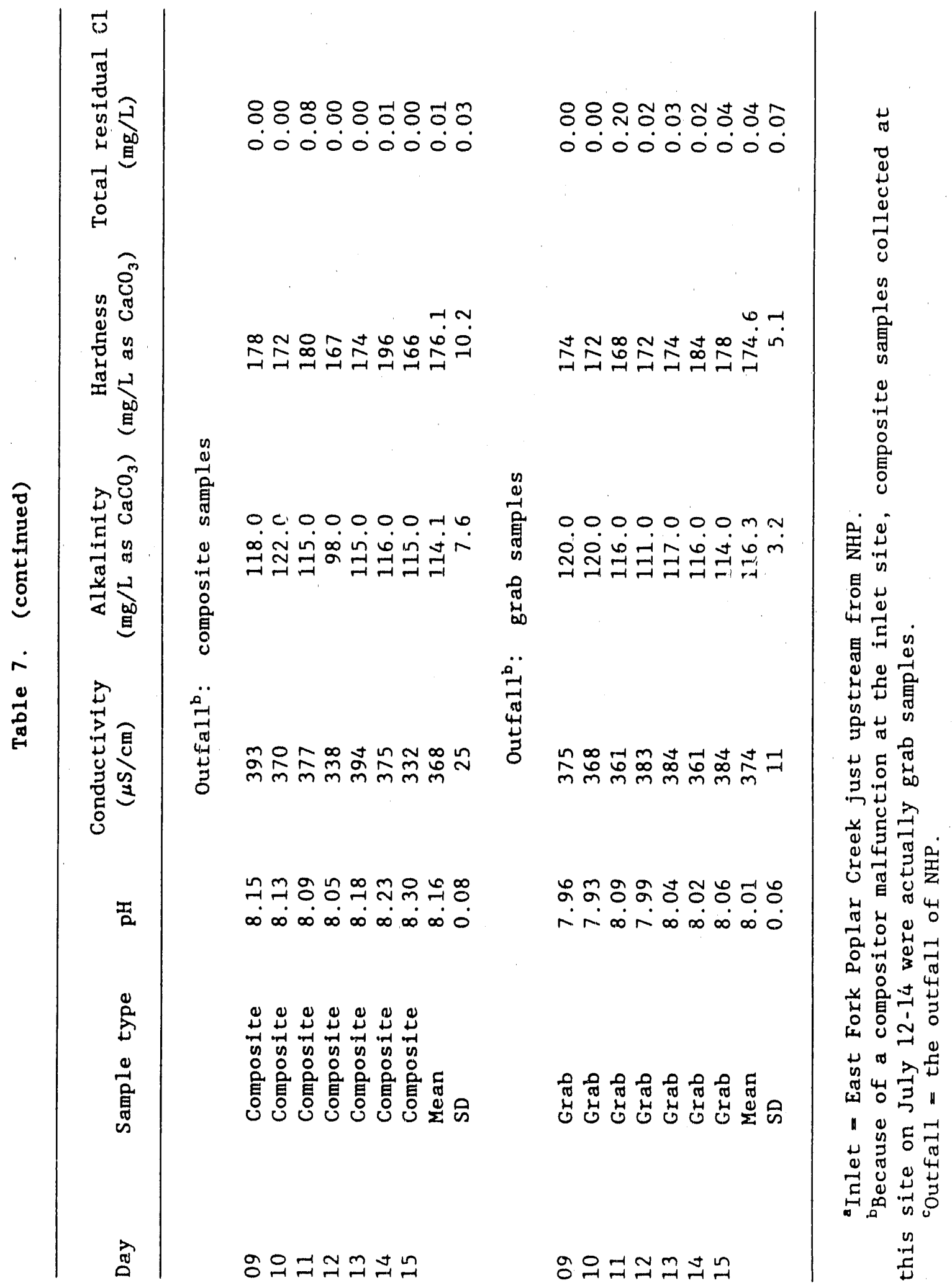




\section{EVALUATION OF POTENTIAL CAUSES OF THE FISH KILI (EPIZOOTIC)}

In developing hypotheses about the cause of the epizootic, several potential sources of stress were identified and evaluated, including (1) overcrowding, (2) high temperatures and rapid changes in temperature, (3) electroshocking, (4) exposure to elevated levels of pollutants, especially $\mathrm{Hg}$, and (5) a combination of stresses. The role of the pathogen and the environmental conditions existing in NHP in initiating the epizootic was also considered. Each of these hypotheses is discussed in the following.

\subsection{OVERCROWDING}

The high population density required for intensive fish culture is a primary factor responsible for disease outbreaks, or epizootics (Wedemeyer et al. 1976). Stoneroller densities below NHP increased by a factor of 10 between March 1986 and March 1987 (Table 8); observable increases in the population were first noted in this region of EFPC in July 1986 (Ryon 1986). The small population size may account, in part, for the absence of BHS in 1985. Although the densities of most species also increased over this same period in this region of EFPC, only the striped shiner (Notropis chrysocephalus) had a density similar to that of the stoneroller, and it was essentially unaffected by BHS. Such an occurrence may not be unusual. The common shiner (Notropis cornutus), a close relative of the striped shiner, was apparently unaffected by an epizootic of Aeromonas liquefaciens (taxonomically the same as A. hydrophila, Wolke 1975) in the Miramichi River in New Brunswick (Pippy and Hare 1969).

The effect of density on mortality rate of stonerollers was tested experimentally in the laboratory. The experimental design consisted of six 20-L aquaria; four tanks recelved no bacteria and two tanks received a known concentration of viable Aeromonas hydrophilia. Within each of tho two groups, stonerollers from an uncontaminated reference stream were stocked at densities of 10 and $20 \mathrm{fish}$ per tank. Thus, the four treatment roups were: (1) no bacteria, low-fish density;

(2) no bacteria, high-fish density; (3) bacteria and low-fish density; and (4) bacteria and high-fish density. 
Table 8. Estimated size of the stoneroller population $\left(\mathbb{N}_{a}\right)$ and

the total fish population $\left(N_{T}\right)$ in a $116-m$ reach of East

Fork Poplar Creek. The study site is located

approximately $200 \mathrm{~m}$ below the outfall of

New Hope Pond. Population estimates

are based on the three-pass removal

method (Carle and Strub 1978)

\begin{tabular}{lccc}
\hline $\begin{array}{l}\text { Sampling } \\
\text { date }\end{array}$ & $\begin{array}{c}\text { Stoneroller } \\
\text { population } \\
\left(\mathrm{N}_{\mathrm{S}}\right)\end{array}$ & $\begin{array}{c}\text { Fish } \\
\text { population } \\
\left(\mathrm{N}_{\mathrm{T}}\right)\end{array}$ & $\begin{array}{c}\text { Percentage } \\
\text { stonerollers } \\
\left(\mathrm{N}_{\mathrm{S}} / \mathrm{N}_{\mathrm{T}}\right)\end{array}$ \\
\hline May 14, 1985 & 0 & 51 & 0 \\
October 22, 1985 & 0 & 341 & 2 \\
January 29, 1986 & 11 & 104 & 0 \\
March 11, 1986 & 0 & 278 & 4 \\
May 15, 1986 & 1047 & 81 & 0 \\
November 10, 1986 & 827 & 2450 & 43 \\
March 3, 1987 & 531 & 1718 & 48 \\
October 26, 1987* & 766 & 1754 & 30 \\
March 13, 1988* & & 1949 & 38 \\
\hline
\end{tabular}

Data collected for a 90-m reach but adjusted to represent $116-\mathrm{m}$ reach. 
Cultures of pure $A$. hydrophilia were obtained from the USFWS National Fish Health Research Laboratory located in Kearneysville, West Virginia. Bacterial suspensions of known density and purity were prepared by streaking a small amount of stock bacteria onto Bacto-agar plates. After sufficient growth of colonies, the bacteria were transferred to trypticase soy broth in $2000 \mathrm{~mL}$ Erlenmeyer flasks and allowed to grow. When an optimum density was reached, the culture fluid was centrifuged to recapture the bacteria. These bacteria were resuspended in a phosphate buffer solution at $\mathrm{pH} 7.2$ to 7.3 before they were added to two of the experimental tanks. For each of the four treatment groups, the time to mortality was recorded for all fish in each tank. The mean time to death was calculated for each group as the mean number of days required for mortality of all fish in each tank.

The experimental combination of high fish density and bacteria had the greatest effect on mortality rate (Fig. 2). Without bacteria, mean time to death was $12.8 \mathrm{~d}$ at the low fish densty and $10.1 \mathrm{~d}$ at the higher density, indicating a slight effect of density alone on mortality. At the low fish density, the mean time to death in the tanks having bacteria was abou: the same as that in the tanks without bacteria. However, at the high densities, mean time to death decreased substantially (Fig. 2). These results suggest that fish density could have been one of the major factors influencing both fish kills.

High densities of fish in the presence of the ubiquitous Aeromonas pathogen may not, however, initiate an epizootic. Disease outbreaks usually occur when fish are stressed by additional environmental factors such as increases of a contaminant or temperature (Meyer 1970;

Wedemeyer 1970). Some evidence suggests that at high fish densities specific biochemical inhibitory factors produced by the fish themselves can cause stress or mortality. Arzapalo et al. (1980) working with Tilapia spp. at high densities, showed that these fish displayed an autoimmune response to hemagglutinins in the mucus. According to Smith (1977), hemagglutinins in fish mucus can induce anaphylactic (secondary) responses of varying degrees of severity in fish. In some instances, these responses predispose fish to disease from secondary etiologic agents and in other cases they cause death directly. Thus, 


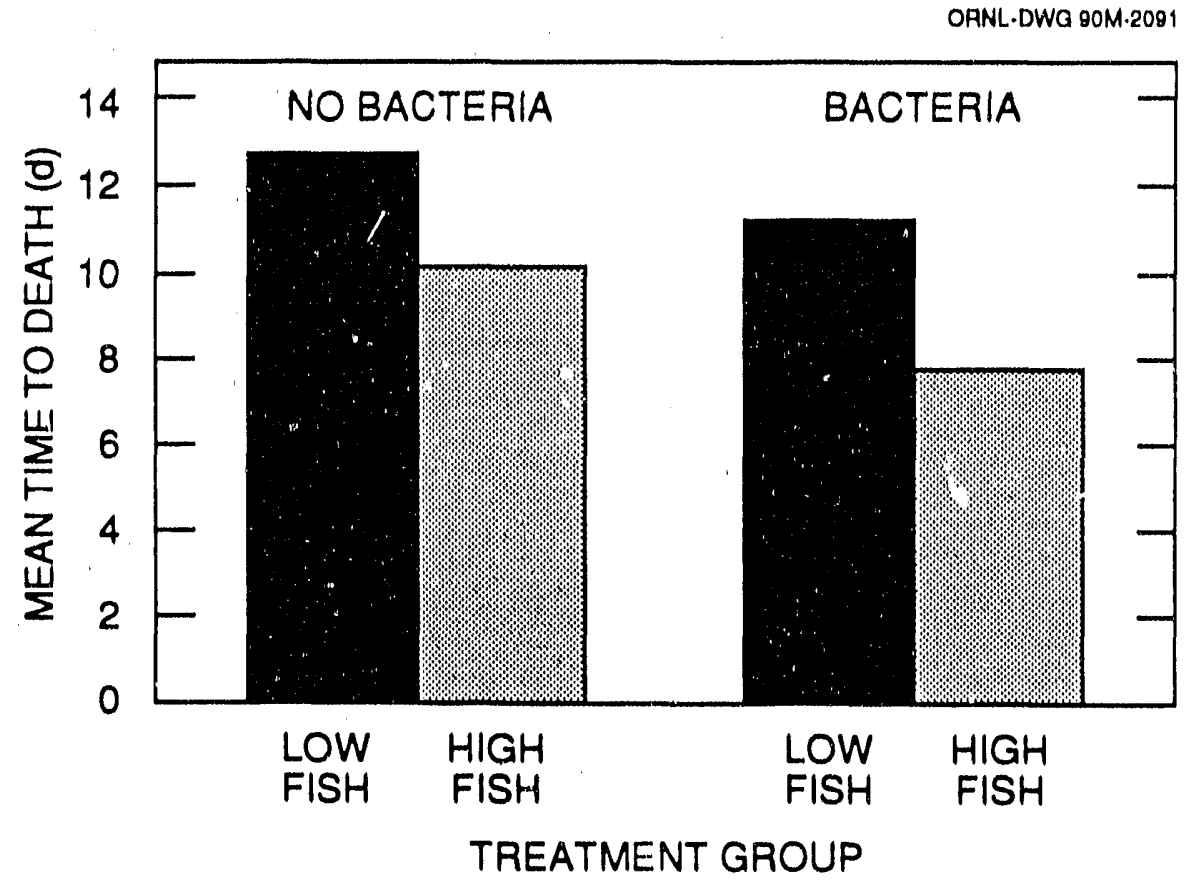

Fig. 2. Effect of bacteria and fish density on the mortality rate (mean number of days required to kill the population in each tank) of stonerollers obtalned from an unpolluted stream. 
overcrowding is not only a stressor but also an agent that enhances the spread of infectiols diseases, such as BHS.

The significance of high densities or overcrowding as a source of stress to the stoneroller population below NHP, however, is unclear because the species normally forms large schools while foraging. Moreover, the densities of 1.93 and 1.42 individuals per square meter observed on November 10, 1986, and March 3, 1987, respectively, in EFPC approximately $200 \mathrm{~m}$ below NHP was similar to that found in May 1986 at other sites located 5 to $15 \mathrm{~km}$ downstream and was more than a factor of 2 lower than the density observed in white Oak Creek east of the ORNL site boundary (Ryon 1987). No evidence of BHS in the White Oak Creek population has been reported.

In addition to their recent high densities below NHP, the stoneroller has a unique feeding habit that may explain why this species was the only one affected by the epizootic. It is an herbivore and grazes on periphyton (attached algae) that is abundant on rock surfaces below NHP. While feeding, stonerollers ingest particulate matter, including fish feces, that settles on the stream bottom. Ingestion is a major pathway in the transmission of BHS between individuals in a population (Wolke 1975). Crowding of a bottom-dwelling species may also explain why the disease is commonly observed in pond culture of catfishes. Although other "bottom-dwelling" fishes inhabit upper EFPC, including the white sucker (Catostomus commersoni), a species that is susceptible to bacterlal disease caused by Aeromonas hydrophila (Pippy and Hare 1969), their densities are at least one or two orders of magnitude below the density of stonerollers.

\subsection{TEMPERATURE}

Like overcrowding, temperature can be a source of environmental stress and can enhance the transmission of BHS. For example, salmonid epizootics caused by BHS can increase dramatically at temperatures above 7 to $10^{\circ} \mathrm{C}$ (Wedemoyer et al. 1976). Also, salmonid mortality rates from Aeromonas infections increase as temperatures increase, with high rates at 17.8 to $20.5^{\circ} \mathrm{C}$ (Fryer et al. 1976). Avallable data suggest that the thermal environment below NHP could have enhanced the spread of the 
pathogen. For example, average dally water temperatures for a 2-week period prior to November 21 were generally above $15^{\circ} \mathrm{C}$ at a site approximately $200 \mathrm{~m}$ below NHP, and maximum temperatures often exceeded $20^{\circ} \mathrm{C}$ (FIg. 3). Mean and maximum dally temperatures were genatally 6 to $7^{\circ} \mathrm{C}$ lower in Brushy Fork, a reference stream located fust north of Oak Ridge. A similar trend occurred in July 1987; mean daily temperatures were 4 to $5^{\circ} \mathrm{C}$ higher and dally maximums were $8^{\circ} \mathrm{C}$ higher in EFPC than in Brushy Fork (FIg. 3).

The thermograph record was also reviewed to determine if a significant drop in air temperatures on November 13-14 (as a result of passage through the region of the first major cold front of the :11) could have caused a correspondingly abrupt change in water temperature and triggered the outbreak of BHS. The maximum water temperature below NHP fust prior to the cold front was $20.8^{\circ} \mathrm{C}$ at $1600 \mathrm{~h}$ on November 12 . Except for a slight rise in temperature in late afternoon of the following day, the temperature declined steadily over the next $36 \mathrm{~h}$ (from $20.8^{\circ}$ to $13.1^{\circ} \mathrm{C}$ at $0600 \mathrm{~h}$ on November 14). The maximum rate of change $\left(0.5^{\circ} \mathrm{C} / \mathrm{h}\right)$ occurred between $1800 \mathrm{~h}$ and inidnight on November 13 , when the water temperature fell from $17.0^{\circ}$ to $14.0^{\circ} \mathrm{C}$. The maximum rate of change in Brushy Fork was $0.3^{\circ} \mathrm{C} / \mathrm{h}$ over approximately the same time period. The abrupt df:cline in water temperatures in EFPC, although greater than that observed in Brushy Fork, was probably not sufficient to have stressed the stoneroller populations and initiated the epizootic (E111ott 1981). These conclusions regarding the November 1986 temperatures were further supported by the lack of any major temperature shifts assoclated with the fish kill in July 1987.

\subsection{ELECTROSHOCKING}

Another potential source of stress on the fish populations below NHP was electroshocking, a technique routinely used to estimate fish population size. Although Mr. Carlson suggested the electroshocking conducted on October 24, 1986, may have caused the outbreak of BHS approximately 4 weeks later, the evidence is not convincing.

A review of the electroshocking pattern in upper EFPC for the period spanning the fish kills (Table 9) Indicates a continual source of 

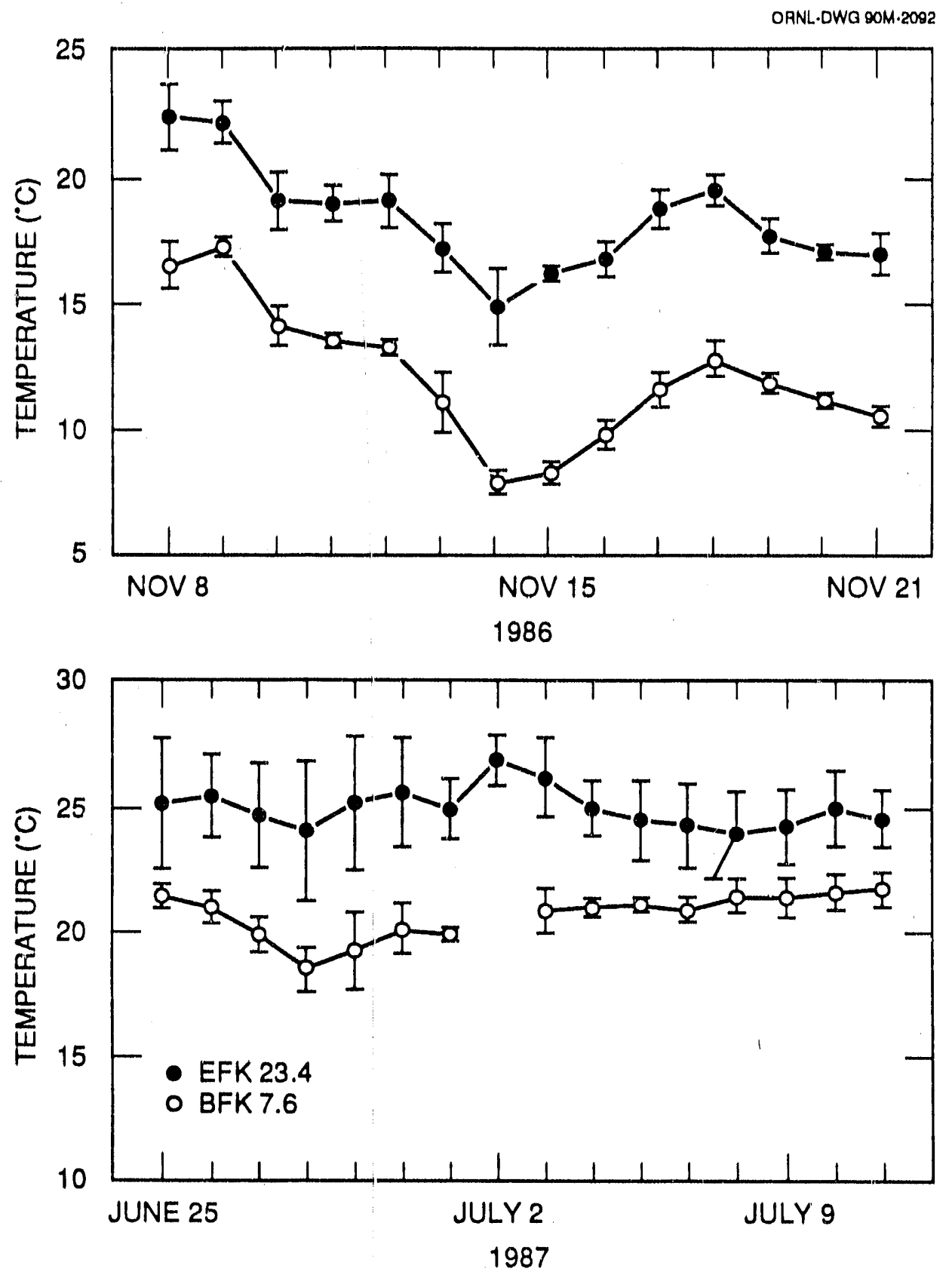

F1g. 3. Dally mean temperatures in East Fork Poplar Creek (EFK) and Brushy Fork (BFK) prior t:o fish kills on November 21, 1986, and July 9, 1987. Temperature ditta were recorded prior to the fish kill at $2-h$ intervals using a Ryan-Plabody thermograph (Mode1 J 90). The temperature data for the second $f i s h$ klll were recorded at $1-h$ intervals using a Ryan TempMentor digttal thermograph. 
Table 9. Electroshocking activities in upper East Fork Poplar Oreek below New Hope Pond during the perlod assoclated with the fish kI11s

\begin{tabular}{|c|c|c|c|c|}
\hline Date & Activity & $\begin{array}{l}\text { Sampling } \\
\text { reach } \\
(\text { EFK“) }\end{array}$ & $\begin{array}{l}\text { Number of } \\
\text { passes } \\
\text { through } \\
\text { reach }\end{array}$ & $\begin{array}{l}\text { Duration of } \\
\text { electroshock } \\
\text { activity } \\
\text { (h) }\end{array}$ \\
\hline $10 / 09 / 86$ & Tagging & $22.0-23.6$ & 1 & 2 \\
\hline $10 / 2.4 / 86$ & $\begin{array}{l}\text { Fish collection for } \\
\text { blood/enzyme analyses }\end{array}$ & $23.0-23.6$ & 1 & 1 \\
\hline $11 / 10 / 86$ & Population estimation ${ }^{\circ}$ & $23.3-23.4$ & 3 & 3 \\
\hline $11 / 21 / 86$ & Fish kill & & & \\
\hline $03 / 03 / 87$ & Population estimation ${ }^{\circ}$ & $23.3-23.4$ & 3 & 2.5 \\
\hline $03 / 20 / 87$ & $\begin{array}{l}\text { Fish collection for } \\
\text { blood/enzyme analyses }\end{array}$ & $23.0-23.6$ & 1 & 1 \\
\hline $03 / 31 / 87$ & Tagging ${ }^{b}$ & $22.0-23.6$ & 1 & 2 \\
\hline $05 / 22 / 87$ & $\begin{array}{l}\text { Fish collection for } \\
\text { contaminant analyses }\end{array}$ & $22.0-23.6$ & 1 & 1 \\
\hline $06 / 18 / 87$ & $\begin{array}{l}\text { Fish collection for } \\
\text { blood/enzyme analyses }\end{array}$ & $23.0-23.6$ & 1 & 0.5 \\
\hline $06 / 25 / 87$ & $\begin{array}{l}\text { Fish collection for } \\
\text { parasite studies }\end{array}$ & $23.1-23.5$ & 1 & 0.5 \\
\hline $07 / 07 / 87$ & Tagging ${ }^{b}$ & $22.0-23.6$ & 1 & 2 \\
\hline $07 / 09 / 87$ & Fisk kil1 & & & \\
\hline
\end{tabular}

-EFK - East Fork Poplar Creek kllometer.

bSunfish only.

cAll species. 
stress. Electroshocking is used below NHP for various collecting purposes, and all incidents could adversely affect the stoneroller population. Before both fish kills, electroshocking occurred on several dates. However, similar periods of electroshocking occurred in March 1987 (some at temperatures similar to those of the November 1986 kili) and had no adverse effect on the stoneroller population. An assumption associated with the electroshocking hypothesis is that stonerollers received more stress or were more susceptible to electroshock: $g$ at one period than at another. Otherwise, BHS would occur following every electroshocking event. Because the mortality of stonerollers was high during the October 24,1986 , sampling trip, it is possible that the population in only this area was under stress from some unknown source (e.g. extreme overcrowding). The additional stress of the electroshocking could have had both immediate and latent effects (i.e., initiation of the epizootic 4 weeks later, as suggested by Mr. Carlson). However, more extensive electroshocking than that used on October 24 was employed on November 10, 1986, during quantitative sampling of the fish populations in a $116-\mathrm{m}$ reach of EFPC approximately $200 \mathrm{~m}$ below NHP. At this time, three consecutive passes with two electroshocking units (compared with one pass with a single unit in October) were made through the study reach. Fish were anesthetized with tricane methanesulfonate, weighed, measured, and then returned to the stream. Even with these additional sources of stress, stoneroller mortality was less than 58, whereas that of the striped shiner, a species unaffected by the epizootic, was substantially higher (43\%). Sampling mortality of the other ten species combined was 48 .

Another problem with designating the October 24 and June 18 electroshocking periods as the primary stress, is related to the length of the incubation period for BHS. At the temperatures that existed in late October 1986 and mid-June 1.987, the incubation period between the first stress and the Aeromonas infection would have been a week or less. This would place the fish kill substantially before November 21 or July 9. Although the electroshocking hypothesis cannot be rejected, additional evidence would be required for electroshocking to be accepted as the stress that caused the outbreaks of BHS. 


\subsection{POLIUTANTS}

\subsubsection{Mercury}

Some data indicate that the epizootic may have been caused by elevated levels of mercury $(\mathrm{Hg})$ associated with a storm-sewer cleaning and relining project at the Y-12 Plant. Total $\mathrm{Hg}$ concentrations in EFPC at the inlet to NHP exceeded $1000 \mathrm{ppb}$ and approached $100 \mathrm{ppb}$ just prior to the November 1986 and July 1987 fish kills, respectively (Appendix D). On both occasions, $\mathrm{Hg}$ concentrations during the preceding 3 weeks ranged from 2 to $4 \mathrm{ppb}$, which is typical for this site. Although there is always some $\mathrm{Hg}$ in the water and sediments below NHP, the elevated levels in November 1986 and July 1987 may have provided enough additional stress to have caused the fish kills. No fish kills have been observed from the time the sewer relining profect was completed in late 1987 until the present (approximately 18 months).

Bioaccumulation of $\mathrm{Hg}$ was measured in November 1986 and July 1987. The $\mathrm{Hg}$ concentration in the alimentary tract of a dead stoneroller collected on November 22 from below NHP was only $8 \mu \mathrm{g} / \mathrm{g}$, wet weight (Appendix E), whereas $\mathrm{Hg}$ concentrations in the surface sediments of the stream in this area range from 20 to $150 \mu \mathrm{g} / \mathrm{g}$. Analysis of more extensive samples taken from stonerollers and a white sucker collected in July 1987 also indicated low $\mathrm{Hg}$ concentrations in intestine, muscle, and whole-body samples (Table 10). Also, the mercury content of periphyton, the food source for stonerollers, was decermined to be $159 \pm 44.0 \mu \mathrm{g} / \mathrm{g}$ (Appendix F). Consequently, stress caused by the uptake of $\mathrm{Hg}$ adsorbed to suspended particulates seems unlikely. However, like many other possible explanations for the kill, elevated $\mathrm{Hg}$ levels in water cannot be refuted as the cause of the fish kill. 
Table 10. Total mercury levels $(\mu g / g)$ in intestine, muscle, and whole-body samples of fish taken from upper

East Fork Poplar Creek during July 1987

\begin{tabular}{|c|c|c|}
\hline $\begin{array}{l}\text { Sample } \\
\text { date }\end{array}$ & $\begin{array}{l}\text { Sample } \\
\text { type }\end{array}$ & $\begin{array}{c}\text { Total } \\
\text { Hg }\end{array}$ \\
\hline & Stoneroller (Campostoma anomalum) & \\
\hline July 16 & Whole body" & 3.39 \\
\hline July 16 & Whole body & 2.04 \\
\hline July 23 & Whole body & 1.77 \\
\hline July 11 & Intestine & 3.4 \\
\hline July 11 & Intestine & 80.0 \\
\hline July 16 & Intestine & 6.0 \\
\hline July 22 & Intestine & 12.0 \\
\hline July 22 & Intestine & 8.9 \\
\hline July 11 & Muscle $e^{b}$ & 1.2 \\
\hline July 11 & Muscle & 1.7 \\
\hline July 16 & Muscle & 1.5 \\
\hline July 22 & Muscle & 1.2 \\
\hline \multirow[t]{2}{*}{ July 22} & Muscle & 1.2 \\
\hline & White sucker (Catostomus commersoni) & \\
\hline July 22 & Intestine & 7.3 \\
\hline July 22 & Muscle & 0.97 \\
\hline
\end{tabular}

ahole body minus intestine and alimentary tract contents.

bMuscle tissue represented in filet. 


\subsubsection{Other Inorganics}

Most other inorganics varied within normal (for NHP outfall) ranges during October-December 1986 (Appendix $\mathrm{G}$ and $\mathrm{H}$ ). Higher-than-normal levels of lithium (approximately 0.2 vs $0.02 \mathrm{ppm}$ ) were noted on several occasions in October and November, and uranium was about ten times higher ( 0.13 to 0.28 vs $0.03 \mathrm{ppm}$ ) in NHP outfall during October 7-13 than that observed in November and December. Prior to and during the fish kill, abnormal levels of nitrate (53 and $25 \mathrm{ppm}$ on November 18-19,1986, vs 2 to 3 ppm on other dates) and residual chlorine ( $0.45 \mathrm{ppm}$ on November 21, 1986, vs <0.1 ppm on other dates) were observed at NHP outfall. The high level of chlorine coincides with the start of the fish kill; however, similar levels were not observed in composited water samples taken for toxicity testing on that date (Table 4).

Concentrations of inorganics in the NHP outfall in June and July 1987 differed from those found in October and December 1986 (Appendix I). Lithium and nitrates had not increased noticeably. However, aluminum levels were increased from normal levels of 0.1 to $0.3 \mathrm{ppm}$ to $1.09,3.24$, and $1.43 \mathrm{ppm}$ on June 19 , July 7 , and July 8 , respectively. Ammonia levels were also elevated to 2.2, 1.4, and $0.9 \mathrm{mg} / \mathrm{L}$ on July $8-10$, respectively. Total residual chlorine concentrations $(\mathrm{mg} / \mathrm{L})$ measured in the outfall of NHP during the ambient toxicity tests were not substantially higher during July 9-15 test $(0.0$ to 0.20$)$ in comparison to other test periods $(0.0$ to 0.14$)$ (Table 7 and Appendix $C$ ).

\subsubsection{Organics}

Numerous organic compounds were detected in NHP inlet and outlet samples between October and December 1986, most at very low levels $(<0.05 \mathrm{ppm})$. (Compounds included in this analys is are listed in Appendices $J$ and $K$. ) The only organic found in excess of 1 ppm was acetone, which exhibited a seemingly random pattern of occasional spikes to levels as high as $47 \mathrm{ppm}$ (October 7, 1986) amidst a normal day-to-day concentration below $0.01 \mathrm{ppm}$. The very high level of acetone observed on October 7 was not corroborated by the total organic carbon (TOC) 
analyses of that sample (6 ppm), suggesting an artifact or sample contamination. There did not appear to be any increase in either TOC or biological oxygen demand (BOD) associated with acetone levels in excess of $1 \mathrm{ppm}$, also suggesting an artificial source.

The other organics most common in NHP inlet and outlet samples were butylcarbitol and another (unidentifled) polymeric ether. When summed, levels of these two organics approached $0.5 \mathrm{ppm}$ on some dates. During the week of the first fish kill (November 18-24), butylcarbitol ranged from 0.006 to $0.41 \mathrm{ppm}$, averaging approximately $0.2 \mathrm{ppm}$, while levels of the other polymeric ether averaged $0.1 \mathrm{ppm}$. It is unlikely that such levels of these compounds were acutely toxic to fish, but data are not available. Levels approaching $0.5 \mathrm{ppm}$ could act as a source of nutrition for microorganisms and pronote their growth in NHP (Sect. 3.6).

Other organics found at lower concentrations and less frequently in these samples included tributyl phosphate, 4-tert-butylphenol, diacetone alcohol, prometone (an herbicide used at the Y-12 Plant for weed control), a substituted diphosphoric acid ester, substituted octadecanoic and hexadecanoic esters, tetrahydrofuran, methylene chloride, methyl chloride, bromoform, phthalates, polyaromatic hydrocarbons, polychlorinated biphenyls, and alkylhydrocarbons.

High levels of TOC ( 86 to $380 \mathrm{ppm}$ ) were observed in NHP outfall samples on November 28, 29, and December 4, 1986. These values were corroborated by high values of chemical oxygen demand but not high BOD. Analysis by gas chromatography/mass spectroscopy did not detect any organics at levels even approximating this high TOC. The nature and source of the high TOC in these samples remains unknown.

Analyses of NHP inlet and outfall samples for organics was also conducted in June and July 1987 as part of a toxicity assessment. No significant concentrations of any organic compounds were detected.

Fish in the reach of EFPC below NHP received intermittent exposures to low levels of a number of inorganic and organic chemicals in the 8 weeks prior to the November fish kill and the month prior to the July fish kill. The most consistent pattern of exposure occurred in the case of mercury, and large peaks in concentration coincided with both 
fish kills. The most toxicologically significant exposure (in terms of known toxic concentrations) was the $0.45 \mathrm{ppm}$ chlorine noted on November 21, the day of the first fish kill. This exposure may have played a role in exacerbating the effects of the bacterial infection already present in the fish population.

\subsection{CUMULATIVE STRESS}

The epizootic might have been caused by cumulative stress. According to this hypothesis, none of the previously mentioned factors (overcrowding, temperature, electroshocking, and elevated $\mathrm{Hg}$ levels) was sufficient to have initiated the outbreak of BHS. However, if it is assumed that they occurred within the same general time frame (approximately a 4-week period prior to the kills), then the fish experienced a cumulative or synergistic stress, eventually resulting in a weakened condition characterized by reduced resistance to disease. Under stress, the immune system becomes dysfunctional, rendering fish more susceptible to mortality from numerous causes (Shul'man 1974; Wedemeyer and McLeay 1981; Anderson, in press).

\subsection{ROLE OF THE PATHOGEN AND NEW HOPE POND}

The last hypcthesis regarding the cause of the epizootic below NHP emphasizes the role of the pathogen Aeromonas hydrophila and the environmental conditions in NHP. Hazen (1979) found that the occurrence of infected largemouth bass (Micropterus salmoides) was significantly correlated with the density of $A$. hydrophila in a South Carolina reservoir. The comparison was even more significant when a time-lag of a month occurred between high pathogen densities and largemouth bass infections. Peak densities of A. hydrophila occurred in June and October.

The environment in EFPC below NHP is assumed to have been stressful for some time prior to the kills as a result of overcrowding and/or chronic exposure to pollutants. Although fish may have been stressed prior to outbreaks of BHS on November 21 and July 9, as indicated by the high mortality that occurred during an electroshocking episode on October 24, no epizootic was observed. This may have been because a 
presumably low pathogen population existed at that time. A later increase in pathogen levels in NHP may have triggered the epizootic that resulted in the November $1986 \mathrm{fish}$ kill.

The BMAP documented significant changes (1.e., senescence) in the aquatic macrophytes in NHP between September and December 1986. Such natural seasonal decomposition of the pond vegetation can, in turn, affect the redox potential of the sediments and the types and concentrations of dissolved and particulate organic matter present in and exported from the pond. In a South Carolina reservoir, high densities of $A$. hydrophila were found in decaying mats of aquatic vegetation (Hazen 1979). If a similar situation existed in NHP, an increase in pathogen densities could have occurred in EFPC during the time of the fish kill(s). Drying commercial fish ponds at least once a year is recommended as one method of reducing the buildup of organic matter and fish pathogens in pond bottoms (Wedemeyer et al. 1976). By comparison, NHP was last cleaned (1.e., dredged) almost 15 years ago. Thus, it is conceivable that pathogen populations in the pond increased significantly, ultimately triggering the outbreak of BHS and resulting in the fish kills. However, this hypothesis lacks direct verification. Virtually nothing is known of microbial population dynamics in NHP. 


\section{ENVIRONMENTAL CONSEQUENCES OR THE EPIZOOTIC}

The impact of the epizootic on the stoneroller population in EFPC can be estimated from BMAP census data. A population size of 1047 individuals was calculated for a $116-\mathrm{m}$ reach of EFPC downstream of NHP in November 1986 prior to the fish kill (Table 8). Assuming that the stoneroller population density in this study section is representative of that over a much larger reach of upper EFPC, the estimated stoneroller population in the $0.5-\mathrm{km}$ reach of EFPC between Bear Creek Road (EFK 23.15) and NHP (EFK 23.65) was 4513 individuals for November 1986. Although dead fish were actually collected over a much larger reach $(1.4 \mathrm{~km})$, it was assumed that many had drifted downstream and that the actual area of the kill was probably more limited. Therefore, a $0.5-\mathrm{km}$ rather than $1.6 \mathrm{~km}$ reach was used in the calculations.

The loss of 1146 individuals as a result of the eplzootic (Table 1) represented a 25 reduction in the stoneroller population of upper EFPC in November 1986. Similar calculations of the fish kill in July 1987 showed that 729 stonerollers died out of an estimated population of 3560, representing 20 mortality. Recognizing that (1) not all of the fish that died from the eplzootic were enumerated [ESD staff and H. Schacher of TWRA agree, however, that the collection efficiency was relatively high (Schacher 1986)] and (2) actual densities just below NHP may have been much higher than 7 to 9 fish per meter of stream, the estimated mortality probably ranged from 20 to 308 of the population. This level of impact on the stoneroller population could be significant. Although the proportion of the total fish population represented by stonerollers increased from 43 to $48 \%$ after the November fish $\mathrm{kill}$, the proportion of stonerollers decreased to only 308 after the July fish kill. Overall, the stoneroller population in the 116-m study section of EFPC below NHP declined by 50 \& between samples taken before and after the two fish kills (Table 8). Recovery of the stoneroller population from the fish kills was indicated by sampling on March 13, 1988, in which both proportion and total stoneroller populatinn increased (Table 8). 


\section{INTERAGENCY INTERACTIONS}

Successful investigation of these flsh kills required extensive interaction and cooperation between several parties, including various organizations within the investigation team (ORNL and Y-12 Plant staffs) and the appropriate regulatory agencies (TWRA and Tennessee Department of Health and Environment). These interactions are summarized in Tables 11 and 12 . 
Table 11. Chronological sequence of interactions between varlous parties responsible for the Investigation of the fish eplzootic that occurred in November 1986 In East Fork Poplar Creak below New Hope Pond. Interactions between staff members of the Environmental Sciences Division (ESD) at Oak Ridge Natlonal Laboratory are not included

\begin{tabular}{|c|c|c|c|c|}
\hline Date & $\begin{array}{l}\text { Type o } \\
\text { Phone } \\
\text { Call }\end{array}$ & $\begin{array}{l}\text { Interact } \\
\text { Meeting }\end{array}$ & $\begin{array}{l}\text { Principal } \\
\text { parties }\end{array}$ & Subject \\
\hline $11 / 21 / 86$ & $x$ & & $\begin{array}{l}\text { J. D. Gass }(Y-12 ; \\
\text { J. M. Loar (ESD) }\end{array}$ & $\begin{array}{l}\text { Notification } \\
\text { of fish kill }\end{array}$ \\
\hline $11 / 21 / 86$ & & $\mathrm{x}$ & $\begin{array}{l}\text { J. M. Loar (ESD) } \\
\text { G. R. Southworth (ESD) } \\
\text { C. Kimbrough }(Y-12)\end{array}$ & $\begin{array}{l}\text { Analysis of } \\
\text { water quality } \\
\text { data }\end{array}$ \\
\hline $11 / 21 / 86$ & $\mathrm{x}$ & & $\begin{array}{l}\text { D. Melgaard (TDHE) } \\
\text { J. M. Loar (ESD) }\end{array}$ & $\begin{array}{l}\text { Call received } \\
\text { but no } \\
\text { interaction }\end{array}$ \\
\hline $11 / 21 / 86$ & & $\mathrm{x}$ & $\begin{array}{l}\text { W. Schacher (TWRA) } \\
\text { J. Evans (TWRA) } \\
\text { J. M. Loar et al. (ESD) }\end{array}$ & $\begin{array}{l}\text { Assist with } \\
\text { fish survey }\end{array}$ \\
\hline $11 / 22 / 86$ & & $\mathrm{x}$ & $\begin{array}{l}\text { W. Schacher (TWRA) } \\
\text { J. M. Loar (ESD) } \\
\text { G. R. Southworth (ESD) }\end{array}$ & $\begin{array}{l}\text { Assist with } \\
\text { fish survey }\end{array}$ \\
\hline $11 / 22 / 86$ & $\mathrm{x}$ & & $\begin{array}{l}\text { J. M. Loar }(E S D) \\
\text { T. R. Butz }(Y-12)\end{array}$ & $\begin{array}{l}\text { Update on fish } \\
\text { kill }\end{array}$ \\
\hline $11 / 23 / 86$ & & $\mathrm{x}$ & $\begin{array}{l}\text { W. Schacher (TWRA) } \\
\text { J. M. Loar (ESD) }\end{array}$ & $\begin{array}{l}\text { Assist with } \\
\text { fish survey }\end{array}$ \\
\hline $11 / 23 / 86$ & $\mathrm{x}$ & & $\begin{array}{l}\text { J. M. Loar }(E S D) \\
\text { T. R. Butz }(Y-12)\end{array}$ & $\begin{array}{l}\text { Update on fish } \\
\text { kill }\end{array}$ \\
\hline $11 / 24 / 86$ & $\mathrm{x}$ & & $\begin{array}{l}\text { J. M. Loar (ESD) } \\
\text { B. Clark (TDHE) }\end{array}$ & $\begin{array}{l}\text { Update on fish } \\
\text { kill }\end{array}$ \\
\hline $11 / 24 / 86$ & & $\mathrm{x}$ & $\mathrm{ESD} / \mathrm{Y}-12 / \mathrm{DOE}$ & $\begin{array}{l}\text { Exchange of } \\
\text { information } \\
\text { on fish kill }\end{array}$ \\
\hline
\end{tabular}


Table 11. (continued)

\begin{tabular}{|c|c|c|c|c|}
\hline Date & $\begin{array}{l}\text { Type o } \\
\text { Phone } \\
\text { Call }\end{array}$ & $\begin{array}{l}\text { Interact } \\
\text { Meeting }\end{array}$ & $\begin{array}{l}\text { Principal } \\
\text { parties }\end{array}$ & Subject \\
\hline $11 / 24 / 86$ & $\mathrm{x}$ & & $\begin{array}{l}\text { C. L. Stair (ESA) } \\
\text { J. M. Loar (ESD) }\end{array}$ & $\begin{array}{l}\text { Update on } f i s h \\
\text { k111 }\end{array}$ \\
\hline $11 / 25 / 86$ & $\mathrm{x}$ & & $\begin{array}{l}\text { J. M. Loar }(\text { ESD) } \\
\text { C. C. Hil1 }(Y-12)\end{array}$ & $\begin{array}{l}\text { Update on fish } \\
\text { kill }\end{array}$ \\
\hline $11 / 26 / 86$ & $\mathrm{x}$ & & $\begin{array}{l}\text { J. M. Loar }(\text { ESD) } \\
\text { C. C. H111 }(Y-12)\end{array}$ & $\begin{array}{l}\text { Update on fish } \\
\text { kill }\end{array}$ \\
\hline $12 / 01 / 86$ & & $x$ & ESD $/ Y-12 / D O E$ & $\begin{array}{l}\text { Exchange of } \\
\text { information } \\
\text { on fish kill }\end{array}$ \\
\hline $12 / 01 / 86$ & $\mathrm{x}$ & & $\begin{array}{l}\text { C. C. H111 }(Y-12) \\
\text { J. M. Loar }(\text { ESD) }\end{array}$ & $\begin{array}{l}\text { Content of } \\
\text { press release }\end{array}$ \\
\hline $12 / 08 / 86$ & $\mathrm{x}$ & & $\begin{array}{l}\text { J. M. Loar (ESD) } \\
\text { W. Schacher (TWRA) }\end{array}$ & $\begin{array}{l}\text { Update on dead } \\
\text { fish count }\end{array}$ \\
\hline $12 / 16 / 86$ & & $\mathrm{x}$ & ESD/Y-12/DOE/TDHE/EPA & $\begin{array}{l}\text { Summary of } \\
\text { fish k111 }\end{array}$ \\
\hline
\end{tabular}

-DOE - Department of Energy; ESA - Environmental and Safety Activities, Martin Marletta Energy Systems, Inc.; TWRA - Tennessee Wildife Resources Agency; TDHE - Tennessee Department of Health and Environment; Y-12 - Health, Safety, Environment and Accountability Division, Y-12 Plant. 
Table 12. Chronological sequence of interactions between varlous parties responsible for the investigation of the fish epizootlc that occurred in July 1987 in East Fork Poplar Creek below New Hope Pond. Interactions between staff members of the Environmental Sclences Division (ESD) at Oak Ridge National Laboretory

are not included

\begin{tabular}{|c|c|c|c|c|}
\hline Date & $\begin{array}{r}\text { Type } \\
\text { Phone } \\
\text { Ca11 }\end{array}$ & $\begin{array}{l}\text { Interiact } \\
\text { Meeting }\end{array}$ & $\begin{array}{l}\text { Principal } \\
\text { parties" }\end{array}$ & Subject \\
\hline $7 / 9 / 87$ & $\mathrm{x}$ & & $\begin{array}{l}\text { C. W. Gehrs (ESD) } \\
\text { J. D. Gass }(Y-12)\end{array}$ & $\begin{array}{l}\text { Notification of } \\
\text { fish kill }\end{array}$ \\
\hline $7 / 9 / 87$ & $\mathrm{X}$ & & $\begin{array}{l}\text { J. D. Gass (Y-12) } \\
\text { C. W. Gehrs (ESD) }\end{array}$ & Update on fish kill \\
\hline $7 / 10 / 87$ & $\mathrm{X}$ & & $\begin{array}{l}\text { J. D. Gass }(Y-12) \\
\text { C. W. Gehrs (ESD) }\end{array}$ & Update on fish kill \\
\hline $7 / 10 / 87$ & $\mathrm{x}$ & & $\begin{array}{l}\text { S. M. Adams (ESD) } \\
\text { C. Carlson (USFWS) }\end{array}$ & $\begin{array}{l}\text { Discussion of } \\
\text { pathogen smears }\end{array}$ \\
\hline $7 / 11 / 87$ & $\mathrm{x}$ & & $\begin{array}{l}\text { J. D. Gass }(Y-12) \\
\text { J. M. Loar }(E S D)\end{array}$ & $\begin{array}{l}\text { Discussion of water } \\
\text { quality data }\end{array}$ \\
\hline $7 / 11 / 87$ & $\mathrm{X}$ & & 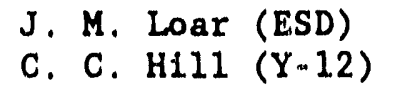 & Update on fish kill \\
\hline $7 / 12 / 87$ & $\mathrm{x}$ & & $\begin{array}{l}\text { C. C. HI11 }(Y-12) \\
\text { J. M. Loar }(E S D)\end{array}$ & Update on fish kill \\
\hline $7 / 13 / 87$ & $\mathrm{x}$ & & $\begin{array}{l}\text { C. C. HIII }(Y-12) \\
\text { J. M. Loar (ESD) }\end{array}$ & Update on fish kill \\
\hline $7 / 13 / 87$ & $\mathrm{X}$ & & $\begin{array}{l}\text { C. C. H111 }(Y-12) \\
\text { J. M. Loar (ESD) }\end{array}$ & $\begin{array}{l}\text { Discussion of water } \\
\text { quality data }\end{array}$ \\
\hline $7 / 14 / 87$ & $\mathrm{x}$ & & $\begin{array}{l}\text { C. C. Hill }(\mathrm{Y}-12) \\
\text { J. M. Loar }\end{array}$ & Update on fish kill \\
\hline $7 / 14 / 87$ & $\mathrm{x}$ & & $\begin{array}{l}\text { C. C. H111 }(Y-12) \\
\text { J. M. Loar (ESD) }\end{array}$ & $\begin{array}{l}\text { Discussion of press } \\
\text { release }\end{array}$ \\
\hline $7 / 14 / 87$ & $\mathrm{x}$ & & $\begin{array}{l}\text { J. M. Loar (ESD) } \\
\text { B. Clark (TDHE) }\end{array}$ & Update on fish k111 \\
\hline
\end{tabular}


Table 12. (continued)

\begin{tabular}{|c|c|c|c|c|}
\hline Date & $\begin{array}{l}\text { Type o } \\
\text { Phone } \\
\text { Cal1 }\end{array}$ & $\begin{array}{l}\text { Interac } \\
\text { Meeting }\end{array}$ & $\begin{array}{l}\text { Principal } \\
\text { parties }\end{array}$ & Subject \\
\hline $7 / 15 / 87$ & $\mathrm{x}$ & & $\begin{array}{l}\text { B. Clark (TDHE) } \\
\text { J. K. Loar (ESD) }\end{array}$ & Update on fish k111 \\
\hline $7 / 15 / 87$ & $\mathrm{x}$ & & $\begin{array}{l}\text { J. M. Loar }(\text { ESD) } \\
\text { C. C. H111 }(Y-12)\end{array}$ & Update on fish kill \\
\hline $7 / 16 / 87$ & $\mathrm{x}$ & & $\begin{array}{l}\text { C. C. Hi11 }(Y-12) \\
\text { J. M. Loar (ESD) }\end{array}$ & Update on fish kil1 \\
\hline $7 / 17 / 87$ & $\mathrm{x}$ & & $\begin{array}{l}\text { C. C. H111 }(Y-12) \\
\text { J. M. Loar (ESD) }\end{array}$ & Update on fish kill \\
\hline $7 / 18 / 87$ & $\mathrm{x}$ & & $\begin{array}{l}\text { C. C. H11I }(Y-12) \\
\text { J. M. Loar (ESD) }\end{array}$ & Update on fish $k 111$ \\
\hline $7 / 19 / 87$ & $\mathrm{x}$ & & $\begin{array}{l}\text { C. C. Hill }(Y-12) \\
\text { J. M. Loar }(\text { ESD) }\end{array}$ & Update on fish kill \\
\hline $7 / 20 / 87$ & & $\mathrm{x}$ & ESD Staff & $\begin{array}{l}\text { Discussion of fish } \\
\quad \text { kill }\end{array}$ \\
\hline $7 / 20 / 87$ & $\mathrm{x}$ & & $\begin{array}{l}\text { J. M. Loer }(\text { ESD) } \\
\text { C. C. HIII }(Y-12)\end{array}$ & Update on fish kill \\
\hline $7 / 21 / 87$ & $\mathrm{x}$ & & $\begin{array}{l}\text { C. C. H111 }(Y-12) \\
\text { J. M. Loar (ESD) }\end{array}$ & Update on fish kill \\
\hline $7 / 21 / 87$ & $\mathrm{x}$ & & $\begin{array}{l}\text { J. M. Loar (ESD) } \\
\text { B. Clark (TDHE) }\end{array}$ & Update on fish kill \\
\hline $7 / 22 / 87$ & $\mathrm{x}$ & & $\begin{array}{l}\text { J. M. Loar }(\text { ESD) } \\
\text { C. C. HIII }\end{array}$ & Update on fish k111 \\
\hline $7 / 23 / 87$ & $\mathrm{x}$ & & $\begin{array}{l}\text { C. C. H111 }(Y-12) \\
\text { J. M. Loar }(\text { ESD })\end{array}$ & Update on fish kill \\
\hline $7 / 27 / 87$ & $\mathrm{x}$ & & $\begin{array}{l}\text { C. C. Hill }(\mathrm{Y}-12) \\
\text { J. M. Loar }(\text { ESD) }\end{array}$ & Update on fish k111 \\
\hline
\end{tabular}


Table 12. (continued)

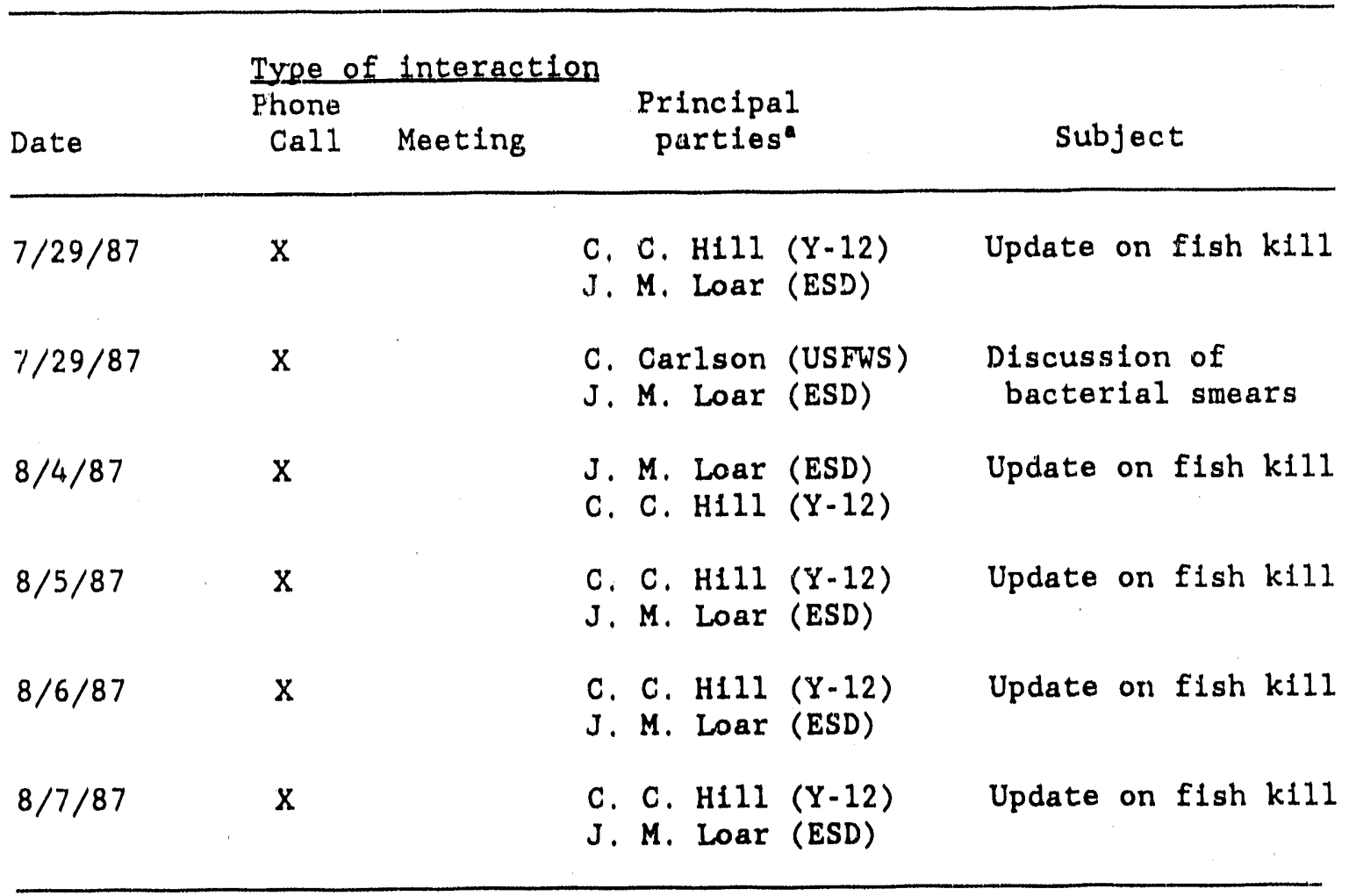

TDHE - Tennessee Department of Health and Environment;

Y-12 - Health, Safety, Environment and Accountability Division, Y-12 Plant; USFWS - U.S. Fish and Wildlife Sclence. 


\section{CONCLUSIONS/RECOMENDATIONS}

The direct causn of the fish kills that were first observed on November 21, 1986, and July 9, 1987, just below the outfall of NHP is attributed to an outbreak of BHS, a stress-mediated disease common in commercial fish culture operations. The pathogen was identified as Aeromonas hydrophila by Charles Carlson, a fish disease specialist with the USFWS, who analyzed kidney samples taken from stonerollers collected below NHP. The disease resulted in a 20 to 30 r reduction in the stoneroller population within a $0.5 \mathrm{~km}$ reach of EFPC below NHP. Their high population densities, strong schooling behavior, and unique benthic feeding habit, in combination with elevated stream temperatures, probably explain why only stonerollers were affected and how the disease was sn rapidly transmitted among individuals in the population.

The cause of the epizootic (i.e., the events or stresses that resulted in an outbreak of BHS) cannot be identified. Overcrowding and temperature were probably more important in promoting the rapid spread of the disease than in initiating the epizootic. The rapid decrease in water temperature that occurred approximately 1 week prior to the outbreak of the disease in November 1986 was probably not a significant factor. Instead, the outbreak may have been caused by (1) electroshocking, (2) elevated levels of mercury associated with the cleaning and relining of highly contaminated storm-sewer lines, (3) cumulative siress from these and other unidentified physical or chemical stressors, or (4) changes in environmental conditions within NHP that enhanced the growth of the pathogen population.

For an epizootic of BHS to occur, the host (fish) must interact with sufficient densities of a pathogen in a stressful environment. Consequently, to control future outbreaks of the disease, information is needed on both the population dynamics of the pathogen and the source(s) of stress in the environment. For example, additional studies would be required to identify environmental conditions that promote the growth of Aeromonas hydrophila populations in NHP. However, such studies are not recommended now because the source of stress that triggered the outbreak could have been elevated $\mathrm{Hg}$ levels. These levels were associated with a 
remedial action (storm sewer cleaning and relining project) that was completed more than 18 months ago. To reduce stress on stoneroller populations, the collection of redbreast sunfish (Lepomis auritus) by electroshocking was combined for the bioaccumulation and biological indicator studies of the BMAP. Techniques were also modified to minimize the exposure of dense schools of stonerollers to electric current. Finally, if total $\mathrm{Hg}$ levels in the discharge from NHP exceed $25 \mathrm{ppb}$, it is recommended that Y-12 Plant staff (1) notify appropriate personnel responsible for biological monitoring (currently J. M. Loar of the Environmental Sciences Division at ORNL) and (2) make frequent observations near the discharge for evidence of an incipient fish kill. Because the cause of the epizootics was not conclusively identified, future outbreaks may be difficult to eliminate. However, the completion of the storm-sewer cleaning and relining project, the closing of NHP, and the restriction of electroshocking activities probably reduced the likelihood of future outbreaks of BHS in upper EFPC. 


\section{REFERENCES}

Anderson, D. P. Immunological indicators: effects of environmental stress on immune protection and disease outbreaks. IN S. M. Adams (ed.), Biological Indicators of Stress in Fish. Amer. Fish. Soc., Bethesda, Md. (In press).

Arzapalo, A. H., R. R. Stickney, and D. H. Lewis. 1980. Immune hypersensitivity in intensively cultured Tilapia species. Trans. Amer. Fish. Soc. 109:244-247.

Carle, F. I., and M. R. Strub. 1978. A new method for estimating population size from removal data. Biometrics 34:621-630.

Cushman, R. M., S. G. Hildebrand, R. H. Strand, and R. M. Anderson. 1977. The toxicity of 35 trace elements in coal to freshwater biota: a data base with automated retrieval capabilities. ORNL/TM - 5793.

Elliott, J. M. 1981. Some aspects of thermal stress on freshwater teleosts. pp. 209-246. IN A. D. Pickering (ed.), Stress and Fish. Academic Press, New York.

Elwood, J. W., R. R. Turner, R. B. Cook, and M. A. Bogle. 1987. Behavior and fish uptake of mercury in a contaminated stream. PP. 58-62. IN S. E. Lindberg and T. C. Hutchinson (eds.), Heavy Metals in the Environment, Vo1. 2, Proc., International Conference, New Orleans, CEP Consultants Ltd., Edinburgh, United Kingdom.

Etnier, E. L., R. E. Meyer, E. B. Lewis, and L. C. Folmar. 1987. Update of acute and chronic aquatic toxicity data for heavy metals and organic chemicals found at hazardous waste sites. ORNL-6392.

Fryer, J. L., K. S. PIlcher, J. E. Sanders, J. S. Rohovec, J. L. Zinn, W. J. Groberg, and R. H. McCoy. 1976. Temperature, infectious diseases, and the immune response in salmonid fish. EPA-600/3-76021. Corvallis Envirormental Research Laboratory, U.S. Environmental Protection Agency, Corvallis, Oregon.

Hazen, T. C. 1579. Ecology of Aeromonas hydrophila in a South Carolina reservair. Microb. Ecol. 5:179-195. 
Kasten, J. L. 1986. Resource management plan for the Oak Ridge Reservation, Vol. 21: water conservation plan for the Dak Ridge Reservation. ORNL/EIS-1/V21.

Loar, J. M. 1988. Description of Study Area. pp. 5-27. IN J. M. Loar (ed.). First annual report on the Y-12 Plant Biological Monitoring and Abatement Program. Draft Report. Oak Ridge National Laboratory, Oak Ridge, Tennessee.

Meyer, F. P. 1970. Seasonal fluctuations in the incidence of disease on fish farms. Amer Fish. Soc. Symp. Spec. Pub. 5:21-29.

Pippy, J. H. C., and G. M. Hare. 1969. Relationship of river pollution to bacterial infection in salmon ( $S a l m o$ salar) and suckers (Catostomus commersoni). Trans. Amer. Fish. Soc. 98:685-690.

Pritz, P. M., and M. Sanders. 1982. Spill-prevention control and countermeasures (SPCC) plan for oil and hazardous substances at the Oak Ridge Y-12 Plant. Y/DD-242, Rev. 2.

Ryon, M. G. 1986. Qualitative survey of fish populations at EFK 23.4. Memo to J. M. Loar, Environmental Sciences Division, Oak Ridge National Laboratory, Oak Ridge, Tennessee, July 17, 1986. Ryon, M. G. 1987. Instream ecological monitoring (fishes). pP. 190-215. IN J. M. Loar (ed), First annual report on the ORNL Biological Monitoring and Abatement Program. Draft Report. ORNL/TM-10399.

Schacher, W. 1986. Personal communication from W. Schacher, Tennessee Wildlife Resources Agency, to J. M. Loar, Environmental Sciences Division, Oak Ridge National Laboratory, Oak Ridge, Tennessee, November 23, 1986.

Shul'man, G. E. 1974. Life Cycles of Fish: Physlology and Biochemistry. John Wiley and Sons, New York.

Smith, A. C. 1977. Reactions of fish red blood cells with mucus and sera from other fish(es). Calif. Fish Game 63:52-57.

Wedemeyer, G. A. 1970. The role of stress in disease resistance of fishes. pp. 30-35. IN S. F. Snieszko (ed.), A Symposium of Fishes and Shellfishes. Amer. Fish. Soc., Washington, D.C. 
Wedemeyer, G. A., F. P. Meyer, and L. Smith. 1976. Environmental stress and fish diseases. Book 5. IN S. F. Snieszko and H. R. Axelrod (eds.), Diseases of Fishes. T. F. H. Publications, Inc., Ltd., Hong Kong.

Wedemeyer, G. A., and D. J. McLeay. 1981. Methods for determining the tolerance of fish to environmental stressors. PP. 247-276. IN A. D. Pickering (ed.). Stress and Fish. Academic Press, New York.

Wolke, R. E. 1975. Pathology of bacterial and fungal diseases affecting fish. PP. 33-116. IN W. E. Ribelin and G. Migaki (eds.). The Pathology of Fishes. University of Wisconsin Press, Madison, Wisconsin. 
APPENDIX A

MEMO FROM L. M. ADAMS (KSZOS), ENVIROMMENTAL SCIENCES DIVISION (ORNL), TO J. M. LOAR, ENVIRONMENTAI SCIENCES DIVISION (ORNL), DESCRIBING RESULTS OF TOXICITY TESTS ON SEWER LINE SLUDGE, USING STONEROLIFRS (Campostoma Anomalum) 
MARTW MARETTA ENEROY SYSTEMS, WC.

To: Jim Loar

From: lymn M. adams LNh Cedams-

$$
\begin{aligned}
& \text { Re d } 12-2-8 t \\
& \lambda c \text { ini } \\
& \text { í: } \\
& \text { Aje }
\end{aligned}
$$

Subject: Toxicity tests with sludge from $Y-12$ Nurthwest sludge basin.

I. Five aquaria were set up on Movember 25 containing $10 \mathrm{~L}$ of dechlorinated tap water and ten Campostoma. Sludge from the Y-12 northwest sludge basin was added to four of the aquaria in approximate concentrations of $30 \mathrm{~g} / \mathrm{L}, 15 \mathrm{~g} / \mathrm{h}$, and $0.5 \mathrm{~g} / \mathrm{L}$. One aquaria with dechlorinated tap water served as a control. After 6 hours of the test, aeration was added to waintain sufficient dissolved oxygen. The two aquaria containing $30 \mathrm{~g} / \mathrm{L}$ were

\begin{tabular}{|c|c|c|c|c|c|c|c|}
\hline $\begin{array}{l}\text { Conc. } \\
(8 / L)\end{array}$ & $\begin{array}{l}\text { No. Fish } \\
\text { Beginning }\end{array}$ & 17 & $\begin{array}{r}\text { Number } \\
24\end{array}$ & $\begin{array}{c}\text { Surviving } \\
67\end{array}$ & $\begin{array}{l}\text { (hours) } \\
87\end{array}$ & 111 & $\begin{array}{l}\text { Turbidity } \\
\text { (NTU) }\end{array}$ \\
\hline $\begin{array}{l}30 \\
30 \\
15 \\
0.5 \\
\text { Control }\end{array}$ & $\begin{array}{l}10 \\
10 \\
10 \\
10 \\
10\end{array}$ & $\begin{array}{r}5 \\
4 \\
8 \\
10 \\
10\end{array}$ & $\begin{array}{r}1 \\
2 \\
5 \\
9 \\
10\end{array}$ & $\begin{array}{r}- \\
- \\
8 \\
10\end{array}$ & $\begin{array}{r}- \\
- \\
8 \\
10\end{array}$ & $\begin{array}{r}- \\
0 \\
7 \\
10\end{array}$ & $\begin{array}{r}>200 \\
>200 \\
> \\
200 \\
\\
\\
\\
\\
23\end{array}$ \\
\hline
\end{tabular}
terminated after 24 hours due to high mortality. I believe the mortality in these aquaria may have been due to high turbidity ( $200 \mathrm{NTU}$ ).

\begin{tabular}{|c|c|c|c|}
\hline $\begin{array}{l}\text { Conc. } \\
(\boldsymbol{c} / L)\end{array}$ & $\begin{array}{l}\text { No Fish } \\
\text { Beginning }\end{array}$ & $\underset{43}{\text { Number Surviving (hours) }}$ & $\begin{array}{l}\text { Turbidity } \\
\text { (NIU) }\end{array}$ \\
\hline $\begin{array}{l}1.0 \\
\text { Control }\end{array}$ & $\begin{array}{r}6 \\
10\end{array}$ & $\begin{array}{r}4 \\
10\end{array}$ & $\begin{array}{l}35 \\
23\end{array}$ \\
\hline
\end{tabular}

II. One additional aquarie was set up on November 26 containing $10 \mathrm{~L}$ of dechlorinated tap water, six Campostoma, and approximately $18 / L$ of the sludge. 
APPENDIX B

LETTER FROM C. P. CARLSON, U.S. FISH AND WILDLIFE SERVICE, TO

S. M. ADAMS, ENVIRONMENTAL SCIENCES DIVISION (ORNL), DESCRIBING RESULTS OF THE LABORATORY TESTS ON STONEROLLERS (Campostoms AnOmalum) 
APPENDIX B

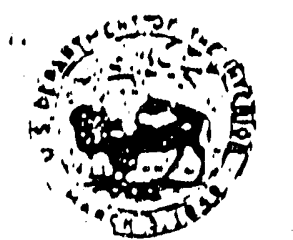

United States Department of the Interior

FISH AND WILOLIFE SERVICE

Hatchery Biologist-Area

P. 0. Box 158

Pisgah Forest, North Carolina 28768

December 2, 1986

rec'd $12-5-86$ gen

\author{
Marshall Adams \\ Building 1505 \\ Mail Stop 36 \\ Oak Ridge National Laboratory \\ P. O. Box $X$ \\ Oak Ridge, TN 37831 \\ Dear Marshall,
}

1 have completed the laboratory tests of kidney material taken from the stonerollers (Campostoma anomalum) at your laboratory on November 26. 1986.

As I reported to you yesterday during our telephone conversation the stonerollers were infected with the bacterium Aeromonas hydrophilin which causes the fish disease bacterial hemorrhagic septicemia (also known as abdominal dropsy, motil aeromonad septicemia, red pest, etc.). These bacteria were isolated on tryptic soy agar (TSA) slants inoculated with kidney material from the stonerollers. $4 / 4$ cultures were positive for Aeromonas hydrophilia from frozen stonerollers collected on November 25, 1986, 2/3 positive from frozen stonerollers collected on November 21, 1986, and 1/2 positive from fresh stonerollers collected on November $26,1986$.

This group of bacteria are found in all natural water and also compose part of the normal intestinal microflora of healehy fish. They can cause the death of fish when they invade internal organs and begin to produce toxins. Stress can initiate an active epizootic of bacterial hemorrhagic septicemia in feral and cultured fish populations. Low oxygen, high water temperatures, handling, crowding, are some of the stress factors which can weaken the fish. The two pools in which the stonerollers died were electrofished last month. This may have produced enough stress on the fish to provoke the epizootic.

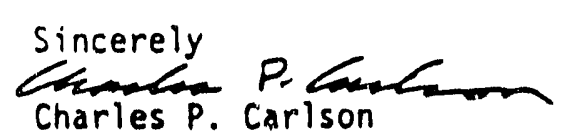

cC: James M. Loar. 
APPENDIX C

WATER QUALITY PARAMETERS MEASURED DURING THE AMBIENT TOXICITY TESTS ON WATER FROM EAST FORK POPLAR CREEK ABOVE AND BELOW NEW HOPE POND, JANUARY-JULY 1987 
Appendix $0, \mathrm{pH}$, conductivity, alkalinfty and hardness, and total residuel chlorine in water from East Fork Poplar Oreek fust upstream from New Hope Pond and Immediately below

New Hope Pond (Inlet and outfall, respectively) for varlous 7 -d perlods in 1987

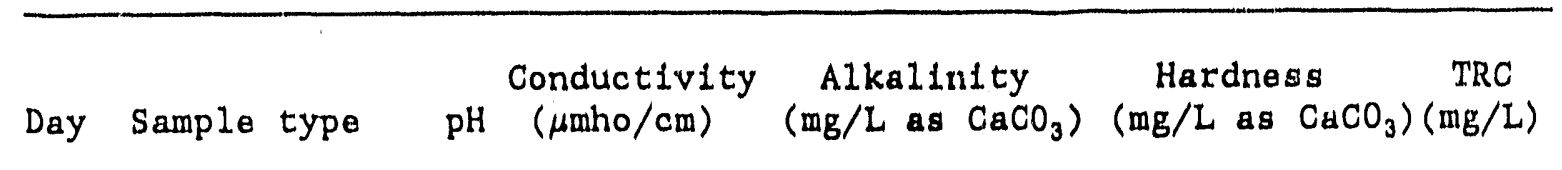

\begin{tabular}{llll}
\hline & & & \\
January & & \\
09 & Composite & 8.08 & 364 \\
10 & Grab & 8.23 & 344 \\
11 & Composite & 8.16 & 428 \\
12 & Composite & 8.10 & 432 \\
13 & Composite & 8.05 & 329 \\
14 & Composite & 8.08 & 398 \\
15 & Composite & 8.16 & 312
\end{tabular}

Inlet

$$
\begin{array}{ll}
\text { January } \\
09 & \text { Grab } \\
10 & \text { Grab } \\
11 & \text { Composite } \\
12 & \text { Composite } \\
13 & \text { Composite } \\
14 & \text { Composite } \\
15 & \text { Composite }
\end{array}
$$

$\begin{array}{llll}05 & \text { Composite } & 8.01 & 438 \\ 06 & \text { Composite } & 8.08 & 395 \\ 07 & \text { Composite } & 8.24 & 416 \\ 08 & \text { Composite } & 8.23 & 331 \\ 09 & \text { Composite } & 8.18 & 418 \\ 10 & \text { Grab } & 8.07 & 388 \\ 11 & \text { Grab } & 8.02 & 357\end{array}$

$\begin{array}{ll}8.06 & 372 \\ 8.20 & 365 \\ 8.12 & 367 \\ 8.11 & 410 \\ 8.10 & 357 \\ 8.12 & 427 \\ 8.11 & 341\end{array}$

8.11

41
February

\begin{tabular}{|c|c|c|c|c|c|c|}
\hline & & & & & & \\
\hline 05 & Composite & 8.07 & 374 & 103.0 & 168 & 0.15 \\
\hline 06 & Grab & 8.00 & 369 & 112.0 & 182 & 0.28 \\
\hline 07 & Grab & 7.83 & 604 & 92.0 & 242 & 0.25 \\
\hline 08 & Grab & 8.12 & 381 & 111.0 & 157 & 0.27 \\
\hline 09 & Grab & 7.83 & 530 & 98.0 & 196 & 0.22 \\
\hline 10 & Grab & 8.03 & 322 & 110.0 & 174 & 0.29 \\
\hline 11 & Grab & 8.03 & 349 & 107.0 & 147 & 0.34 \\
\hline
\end{tabular}

Inlet

$\begin{array}{lll}103.0 & 162 & 0.37 \\ 109.0 & 168 & 0.34 \\ 104.0 & 164 & 0.17 \\ 107.0 & 154 & 0.26 \\ 104.0 & 144 & 0.64 \\ 100.0 & 170 & 0.27 \\ 100.0 & 130 & 0.28\end{array}$

Qutfall

$\begin{array}{rll}102.0 & 164 & 0.14 \\ 112.0 & 164 & 0.04 \\ 100.0 & 173 & 0.02 \\ 98.0 & 146 & 0.10 \\ 102.0 & 160 & 0.06 \\ 97.0 & 170 & 0.13 \\ 95.0 & 136 & 0.12\end{array}$

Qutfall

$\begin{array}{rrr}96.0 & 154 & 0.04 \\ 108.0 & 178 & 0.04 \\ 118.0 & 176 & 0.03 \\ 105.0 & 157 & 0.03 \\ 114.0 & 162 & 0.02 \\ 105.0 & 152 & 0.11 \\ 106.0 & 160 & 0.11\end{array}$

Inlet 
Appendix $0 . \quad$ (continued)

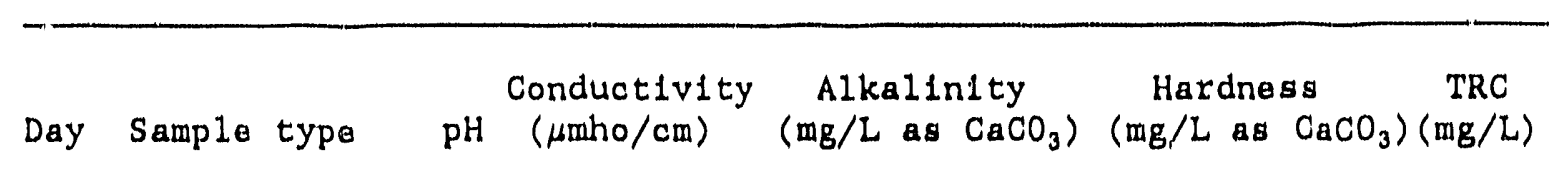

March

\begin{tabular}{|c|c|c|c|c|c|c|}
\hline \multirow{2}{*}{\multicolumn{7}{|c|}{ Qutfall }} \\
\hline \multirow{2}{*}{\multicolumn{7}{|c|}{${ }_{0.5}^{\operatorname{larch}}$ Compest te }} \\
\hline & & & & & & \\
\hline 06 & Composite & 8.01 & 368 & 112.0 & 166 & 0.04 \\
\hline 07 & Compost te & 8.15 & 344 & 112.0 & 170 & 0.02 \\
\hline 08 & Composite & 8.23 & 358 & 1.08 .0 & 174 & 0.00 \\
\hline 09 & Composite & 8.03 & 376 & 112.0 & 158 & 0.00 \\
\hline 10 & Composite & 7.98 & 360 & 103.0 & 166 & 0.00 \\
\hline \multirow[t]{2}{*}{11} & Composite & 8.02 & 412 & 109.0 & 172 & 0.05 \\
\hline & & & & & & \\
\hline \multicolumn{7}{|c|}{ Apr 11} \\
\hline 09 & Composite & 8,24 & 440 & 116.5 & 186 & 0.00 \\
\hline 10 & Composite & 8.16 & 390 & 110.0 & 142 & 0.00 \\
\hline 11 & Composite & 8.47 & 307 & 115.0 & 170 & 0.00 \\
\hline 12 & Composite & 8.35 & 337 & 109.0 & 1.60 & 0.00 \\
\hline 13 & Composite & 8.14 & 331 & 109.0 & 162 & 0.00 \\
\hline 14 & Composite & 8.34 & 341 & 107.0 & 154 & 0.00 \\
\hline \multirow[t]{2}{*}{15} & Composite & 7.99 & 3.30 & 128.0 & 122 & 0.00 \\
\hline & \multicolumn{6}{|c|}{ Intet } \\
\hline \multicolumn{7}{|c|}{ May } \\
\hline 07 & Composite & 8.21 & 471 & 119.0 & 178 & 0.06 \\
\hline 08 & Composite & 8.04 & 477 & 114.0 & 178 & 0.04 \\
\hline 09 & Composite & 8.05 & 461 & 112.0 & 186 & 0.03 \\
\hline 10 & Composite & 8.11 & 457 & 112.0 & 160 & 0.00 \\
\hline 11 & Composite & 8.22 & 491 & 107.0 & 198 & 0.00 \\
\hline 12 & Composite & 8.13 & 461 & 109.0 & 178 & 0.02 \\
\hline \multirow[t]{2}{*}{13} & Composite & 8.18 & 461 & 112.0 & 186 & 0.01 \\
\hline & \multicolumn{6}{|c|}{ Qutfold } \\
\hline \multicolumn{7}{|c|}{ May } \\
\hline 07 & Composite & 8.70 & 480 & 118.0 & 184 & 0.00 \\
\hline 08 & Composite & 8.70 & 426 & 116.0 & 204 & 0.00 \\
\hline 09 & Composite & 8.76 & 455 & 116.0 & 170 & 0.00 \\
\hline 10 & Composite & 8.52 & 480 & 112.0 & 168 & 0.02 \\
\hline 11 & Composite & 8.70 & 472 & 111.0 & 188 & 0.00 \\
\hline 12 & Composite & 8.59 & 429 & 110.0 & 164 & 0.00 \\
\hline 13 & Composite & 8.34 & 447 & 111.0 & 190 & 0.00 \\
\hline
\end{tabular}

outfald 


$$
C-5
$$

Append1x $0 . \quad$ (continued)

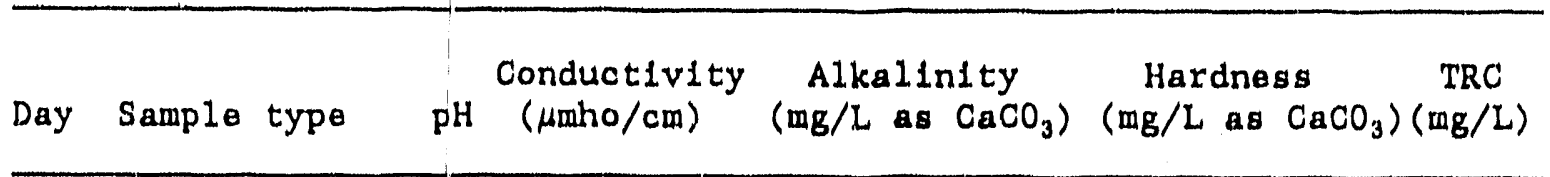

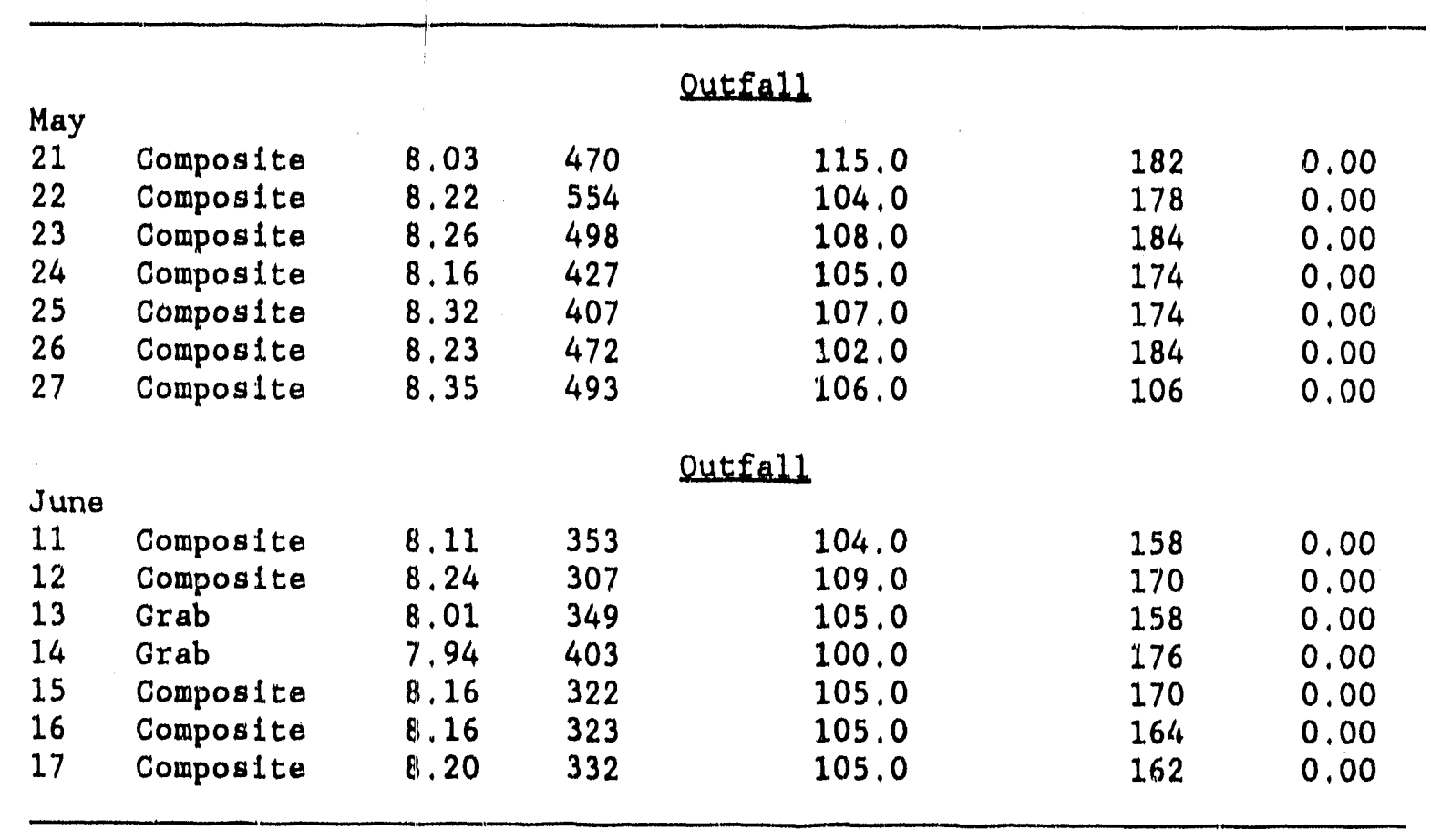




\begin{abstract}
APPENDIX D
CONOENTRATION OF TOTAL MERCURY (mg/L) IN GRAB SAMPLES COLLECTED AT NEW HOPE POND FROM OCTC BER 27 THROUGH DECEMBER 15, 1986, AND FROM JUNE 1 THROUGH JULY 20, 1987
\end{abstract}


D-3

Append Ix D

\begin{tabular}{|c|c|c|c|}
\hline Date & Time & Inlet. & Outlet \\
\hline \multirow[t]{3}{*}{$10 / 27 / 86$} & 0930 & 0.0024 & 0.0000 \\
\hline & 0935 & 0.0000 & 0.0011 \\
\hline & 1500 & 0.0026 & 0.0010 \\
\hline \multirow{2}{*}{$10 / 28 / 86$} & 1050 & 0.0024 & 0.0013 \\
\hline & 1530 & 0.0042 & 0.0019 \\
\hline \multirow[t]{2}{*}{$10 / 29 / 86$} & 0915 & 0.0026 & 0.0013 \\
\hline & 1435 & 0.0027 & 0.0014 \\
\hline \multirow[t]{2}{*}{$10 / 30 / 86$} & 0950 & 0.0028 & 0.0012 \\
\hline & 1530 & 0.0021 & 0.0022 \\
\hline \multirow[t]{2}{*}{$10 / 31 / 86$} & 1035 & 0.0024 & 0.0013 \\
\hline & 1430 & 0.0022 & 0.0019 \\
\hline \multirow[t]{2}{*}{$11 / 03 / 86$} & 1000 & 0.0022 & 0.0014 \\
\hline & 1445 & 0.0035 & 0.0019 \\
\hline \multirow[t]{2}{*}{$11 / 04 / 86$} & 0845 & 0.0021 & 0.0013 \\
\hline & 1500 & 0.0026 & 0.0020 \\
\hline \multirow[t]{2}{*}{$11 / 05 / 86$} & 091.5 & 0.0020 & 0.0013 \\
\hline & 1425 & 0.0019 & 0.0015 \\
\hline \multirow[t]{2}{*}{$11 / 06 / 86$} & 0915 & 0.0018 & 0.0013 \\
\hline & 1440 & 0.0018 & 0.0018 \\
\hline \multirow[t]{2}{*}{$11 / 07 / 86$} & 0945 & 0.0013 & 0.0014 \\
\hline & 1430 & 0.0015 & 0.0011 \\
\hline \multirow[t]{2}{*}{$11 / 10 / 86$} & 0925 & 0.0020 & 0.0018 \\
\hline & 1445 & 0.0017 & 0.0013 \\
\hline \multirow{2}{*}{$11 / 11 / 86$} & 0920 & 0.0023 & 0.0014 \\
\hline & 1450 & 0.0019 & 0.0016 \\
\hline \multirow[t]{2}{*}{$11 / 12 / 86$} & 1020 & 0.0016 & 0.0010 \\
\hline & 1505 & 0.0022 & 0.0014 \\
\hline \multirow[t]{2}{*}{$11 / 13 / 86$} & 0945 & 0.0021 & 0.0014 \\
\hline & 1540 & 0.0018 & 0.0015 \\
\hline \multirow[t]{2}{*}{$11 / 14 / 86$} & 1001 & 0.0036 & 0.0043 \\
\hline & 1500 & 0.0022 & 0.0022 \\
\hline \multirow{3}{*}{$\begin{array}{l}11 / 17 / 86 \\
11 / 18 / 86\end{array}$} & 0900 & 0.0015 & 0.0012 \\
\hline & 0845 & 0.0032 & 0.0022 \\
\hline & 1415 & 0.0045 & 0.0020 \\
\hline \multirow[t]{2}{*}{$11 / 19 / 86$} & 1000 & 0.0033 & 0.0019 \\
\hline & 1500 & 1.400 & 0.0022 \\
\hline \multirow[t]{2}{*}{$11 / 20 / 86$} & 0900 & 0.0110 & 0.0100 \\
\hline & 1510 & 0.0420 & 0.0640 \\
\hline \multirow{3}{*}{$\begin{array}{l}11 / 21 / 86 \\
11 / 24 / 86\end{array}$} & 0915 & 0.0200 & 0.0120 \\
\hline & 0915 & 0.0140 & 0.0076 \\
\hline & 1550 & 0.0070 & 0.0040 \\
\hline \multirow[t]{2}{*}{$11 / 25 / 86$} & 1000 & 0.0060 & 0.0032 \\
\hline & 1415 & 0.0082 & 0.0037 \\
\hline \multirow{2}{*}{$11 / 26 / 88$} & 0900 & 0.0044 & 0.0027 \\
\hline & 1400 & 0.0036 & 0.0025 \\
\hline
\end{tabular}


Append1x D. (continued)

\begin{tabular}{|c|c|c|c|}
\hline Date & Time & Inlet & Outlet \\
\hline \multirow[t]{2}{*}{$12 / 01 / 86$} & 0950 & 0.0044 & 0.0043 \\
\hline & 1435 & 0.0042 & 0.0029 \\
\hline \multirow[t]{2}{*}{$12 / 02 / 86$} & 0845 & 0.0030 & 0.0021 \\
\hline & 1320 & 0.0030 & ز.0020 \\
\hline \multirow[t]{2}{*}{$12 / 03 / 86$} & 0855 & 0.0040 & 0.0024 \\
\hline & 1445 & 0.0220 & 0.0027 \\
\hline \multirow[t]{2}{*}{$12 / 04 / 86$} & 0905 & 0.0038 & 0.0056 \\
\hline & 1430 & 0.0190 & 0.0039 \\
\hline \multirow{3}{*}{$\begin{array}{l}12 / 05 / 86 \\
12 / 06 / 86\end{array}$} & 0920 & 0.0700 & 0.0380 \\
\hline & 0920 & 0.0170 & 0.0110 \\
\hline & 2015 & 0.0170 & 0.0110 \\
\hline \multirow[t]{3}{*}{$12 / 07 / 86$} & 1450 & 0.0180 & 0.0078 \\
\hline & 1930 & 0.0660 & 0.0092 \\
\hline & 2240 & 0.0200 & 0.0088 \\
\hline \multirow[t]{3}{*}{$12 / 08 / 86$} & 0915 & 0.0110 & 0.0100 \\
\hline & 1445 & 0.0110 & 0.0060 \\
\hline & 1450 & 0.0710 & 0.0330 \\
\hline \multirow[t]{2}{*}{$12 / 09 / 86$} & 0910 & 0.0070 & 0.0050 \\
\hline & 1415 & 0.0090 & 0.0080 \\
\hline \multirow[t]{2}{*}{$12 / 10 / 86$} & 0855 & 0.0046 & 0.0026 \\
\hline & 1500 & 0.0044 & 0.0044 \\
\hline \multirow[t]{2}{*}{$12 / 11 / 86$} & 0915 & 0.0036 & 0.0020 \\
\hline & 1430 & 0.0030 & 0.0019 \\
\hline \multirow[t]{2}{*}{$12 / 12 / 86$} & 0850 & 0.0036 & 0.0027 \\
\hline & 1430 & 0.0078 & 0.0031 \\
\hline \multirow[t]{2}{*}{$12 / 15 / 86$} & 0955 & 0.0046 & 0.0024 \\
\hline & 1430 & 0.0400 & 0.0031 \\
\hline \multicolumn{2}{|l|}{ Min } & 0.0013 & 0.0000 \\
\hline \multirow{2}{*}{\multicolumn{2}{|c|}{$\begin{array}{l}\text { Max } \\
\text { Mean }\end{array}$}} & 1.400 & 0.0640 \\
\hline & & 0.0288 & 0.0051 \\
\hline \multirow[t]{2}{*}{$6 / 01 / 87$} & 0910 & 0.0032 & 0.0019 \\
\hline & 1530 & 0.0050 & 0.0021 \\
\hline \multirow[t]{2}{*}{$6 / 02 / 87$} & 0820 & 0.0028 & 0.0120 \\
\hline & 1400 & 0.0054 & 0.0019 \\
\hline \multirow[t]{2}{*}{$6 / 03 / 87$} & 1015 & 0.0030 & 0.0014 \\
\hline & 1400 & 0.0022 & 0.0018 \\
\hline \multirow[t]{2}{*}{$6 / 04 / 87$} & 0910 & 0.0026 & 0.0012 \\
\hline & 1510 & 0.0020 & 0.0012 \\
\hline \multirow[t]{2}{*}{$6 / 05 / 87$} & 0930 & 0.0032 & 0.0026 \\
\hline & 1330 & 0.0120 & 0.0030 \\
\hline \multirow[t]{2}{*}{$6 / 08 / 87$} & 0945 & 0.0036 & 0.0013 \\
\hline & 1600 & 0.0030 & 0.0016 \\
\hline \multirow[t]{2}{*}{$5 / 09 / 87$} & 1100 & 0.0030 & 0.0012 \\
\hline & 1500 & 0.0026 & 0.0014 \\
\hline
\end{tabular}


Appendix D. (continued)

\begin{tabular}{|c|c|c|c|}
\hline Date & Time & Inlet & Outlet \\
\hline \multirow[t]{2}{*}{$6 / 10 / 87$} & 0950 & 0.0032 & 0.0011 \\
\hline & 1445 & 0.0028 & 0.0019 \\
\hline \multirow[t]{2}{*}{$6 / 11 / 87$} & 0915 & 0.0030 & 0.0012 \\
\hline & 1530 & 0.0046 & 0.0022 \\
\hline \multirow[t]{2}{*}{$6 / 12 / 87$} & 0850 & 0.0036 & 0.0014 \\
\hline & 1300 & 0.0032 & 0.0016 \\
\hline \multirow[t]{2}{*}{$6 / 15 / 87$} & 0850 & 0.0026 & 0.0013 \\
\hline & 1410 & 0.0034 & 0.0018 \\
\hline \multirow{2}{*}{$6 / 16 / 87$} & 0955 & 0.0038 & 0.0011 \\
\hline & $1 \div 20$ & 0.0064 & 0.0018 \\
\hline \multirow{2}{*}{$6 / 17 / 87$} & 0830 & 0.0030 & 0.0015 \\
\hline & $1230^{\circ}$ & 0.0024 & 0.0020 \\
\hline \multirow[t]{2}{*}{$6 / 18 / 87$} & 0830 & 0.0024 & 0.0010 \\
\hline & 1315 & 0.0026 & 0.0017 \\
\hline \multirow[t]{2}{*}{$6 / 19 / 87$} & 0955 & 0.0022 & 0.0013 \\
\hline & 1500 & 0.0058 & 0.0015 \\
\hline \multirow[t]{2}{*}{$6 / 22 / 87$} & 0955 & 0.0020 & 0.0011 \\
\hline & 1300 & 0.0024 & 0.0013 \\
\hline \multirow[t]{2}{*}{$6 / 23 / 87$} & 1120 & 0.0150 & 0.0014 \\
\hline & 1300 & 0.0130 & 0.0020 \\
\hline \multirow[t]{2}{*}{$6 / 24 / 87$} & 1105 & 0.0110 & 0.0024 \\
\hline & 1430 & 0.0052 & 0.0025 \\
\hline \multirow[t]{2}{*}{$6 / 25 / 87$} & 0915 & 0.0042 & 0.0016 \\
\hline & 1430 & 0.0084 & 0.0024 \\
\hline \multirow[t]{2}{*}{$6 / 26 / 87$} & 1115 & 0.0120 & 0.0021 \\
\hline & 1535 & 0.0060 & 0.0038 \\
\hline \multirow[t]{2}{*}{$6 / 29 / 87$} & 0850 & 0.0054 & 0.0020 \\
\hline & 1410 & 0.0080 & 0.0032 \\
\hline \multirow[t]{2}{*}{$6 / 30 / 87$} & 0755 & 0.0054 & 0.0019 \\
\hline & 1430 & 0.0066 & 0.0023 \\
\hline \multirow{2}{*}{$7 / 01 / 87$} & 0750 & 0.0060 & 0.0018 \\
\hline & 1410 & 0.0120 & 0.0025 \\
\hline \multirow[t]{2}{*}{$7 / 02 / 87$} & 0820 & 0.0044 & 0.0020 \\
\hline & 1410 & 0.0098 & 0.0024 \\
\hline \multirow[t]{2}{*}{$7 / 07 / 87$} & 0820 & 0.0036 & 0.0062 \\
\hline & 1415 & 0.0230 & 0.0079 \\
\hline \multirow[t]{2}{*}{$7 / 08 / 87$} & 0900 & 0.0200 & 0.0090 \\
\hline & 1330 & 0.0900 & 0.0100 \\
\hline \multirow[t]{2}{*}{$7 / 09 / 87$} & 0815 & 0.0250 & 0.0120 \\
\hline & 1325 & 0.0220 & 0.0088 \\
\hline \multirow[t]{2}{*}{$7 / 10 / 87$} & 0820 & 0.0210 & 0.0086 \\
\hline & 1335 & 0.0240 & 0.0110 \\
\hline \multirow[t]{4}{*}{$7 / 13 / 87$} & 0910 & 0.0088 & 0.0072 \\
\hline & 1400 & 0.0000 & 0.0045 \\
\hline & 1420 & 0.0090 & 0.0054 \\
\hline & 1500 & 0.0110 & 0.0000 \\
\hline
\end{tabular}


Appendix D. (continued)

\begin{tabular}{llll}
\hline Date & Time & Inlet & Outlet \\
\hline $7 / 14 / 87$ & 0830 & 0.0240 & 0.0120 \\
$7 / 15 / 87$ & 141.5 & 0.0170 & 0.0140 \\
$7 / 16 / 87$ & 0830 & 0.0140 & 0.0065 \\
$7 / 17 / 87$ & 1315 & 0.1400 & 0.0840 \\
$7 / 18 / 87$ & 0900 & 0.0520 & 0.0270 \\
& 1420 & 0.0310 & 0.0240 \\
$7 / 19 / 87$ & 1050 & 0.0290 & 0.0140 \\
$7 / 20 / 87$ & 1430 & 0.0180 & 0.0130 \\
& 0830 & 0.0200 & 0.0100 \\
Min & 0945 & 0.0180 & 0.0085 \\
Max & 1115 & 0.0270 & 0.0095 \\
Mean & 0815 & 0.0140 & 0.0070 \\
& 1100 & 0.0170 & 0.0088 \\
& 0850 & 0.0230 & 0.0170 \\
& 1450 & 0.0170 & 0.0050 \\
& & 0.0000 & 0.0000 \\
& & 0.1400 & 0.0840 \\
& & 0.0129 & 0.0060 \\
\hline
\end{tabular}


APPENDIX E

CONCENTRATIONS OF INORGANIC CHEMICALS ( $\mu g / 8$ ) IN THE GUT CONTENTS OF STONEROLIERS (Campostoma AnOmalum) COLLECTED ON NOVEMBER 22, 1986 
Appendix $\mathrm{E}$

REQ: A02194.

HNO3 DISSOLUTION AND FILTERED

UNITS: $\mathrm{mg} / \mathrm{kg}(-\mu \mathrm{g} / \mathrm{g})$

$D F=11.7683$

PREP BY: MJF

DATE: $11 / 22 / 86$

ID: ENV ICP

BASIS: AS RECEIVED

PROC \$: 556

ANAL BY: MJF

FROM:DLI : FISH3 . BRNINSTR
Concentrations

$(\mu \mathrm{g} / \mathrm{g})$

Concentrations

$(\mu \mathrm{g} / \mathrm{g})$

\begin{tabular}{lclc}
$\mathrm{Ag}$ & 2.2 & $\mathrm{Mg}$ & 440 \\
$\mathrm{Al}$ & 615 & $\mathrm{Mn}$ & 177 \\
$\mathrm{As}$ & $<3$ & $\mathrm{Mo}$ & 0.7 \\
$\mathrm{~B}$ & $<0.5$ & $\mathrm{Na}$ & 1390 \\
$\mathrm{Ba}$ & 16.3 & $\mathrm{Nb}$ & $<0.6$ \\
$\mathrm{Be}$ & 0.072 & $\mathrm{NI}$ & 6.4 \\
$\mathrm{Ca}$ & 1770 & $\mathrm{P}$ & 1900 \\
$\mathrm{Cd}$ & 1.4 & $\mathrm{~Pb}$ & 3 \\
$\mathrm{Ce}$ & 1.4 & $\mathrm{Sc}$ & 0.13 \\
$\mathrm{Co}$ & 2.4 & $\mathrm{Sr}$ & 3.64 \\
$\mathrm{Cr}$ & 3.1 & $\mathrm{Th}$ & $<0.6$ \\
$\mathrm{Cu}$ & 30.2 & $\mathrm{TI}$ & 4.4 \\
$\mathrm{Fe}$ & 1390 & $\mathrm{~V}$ & 0.7 \\
$\mathrm{Ga}$ & $<0.6$ & $\mathrm{Zn}$ & 109 \\
$\mathrm{~K}$ & 1570 & $\mathrm{Zr}$ & 0.4 \\
$\mathrm{La}$ & 0.4 & $\mathrm{Hg}$ & 8 \\
$\mathrm{LI}$ & 1.22 & & \\
& & & \\
\hline
\end{tabular}


APPENDIX $\mathbf{F}$

MERCURY CONTENT OF PERIPHYTON, FEBRUARY 10, 1987 


\section{MERCURY CONTENT OF PERIPHYTON}

MARCH 7, 1987

Rocks containing periphyton were collected from shallow riffle areas in East Fork Poplar Creek and several streams in white Oak Creek watershed. These sites are included in the Biological Monitoring and Abatement Programs for the Y-12 Plant and ORNL, respectively. The rocks were collected by H. L. Boston and R. D. Balley on February 10, 1987, and were taken to the laboratory in plastic containers of stream water from the collection sites. In the laboratory, the periphyton was scraped from the rock surfaces using a plastic bristled toothbrush. Triplicate samples were scraped into three aluminum pans and oven-dried for $42 \mathrm{~h}$ at $65^{\circ} \mathrm{C}$. A 30 - to 50 -mg subsample of each dried sample was scraped into a clean scintillation vial and submitted for $\mathrm{Hg}$ analysis.

The $\mathrm{Hg}$ content was determined by cold vapor extraction and atomic absorption spectroscopy. The results are presented in the following table as ppm Hg on a dry weight basis. The data shown are the mean concentration ( \pm 1 SD) for three replicates.

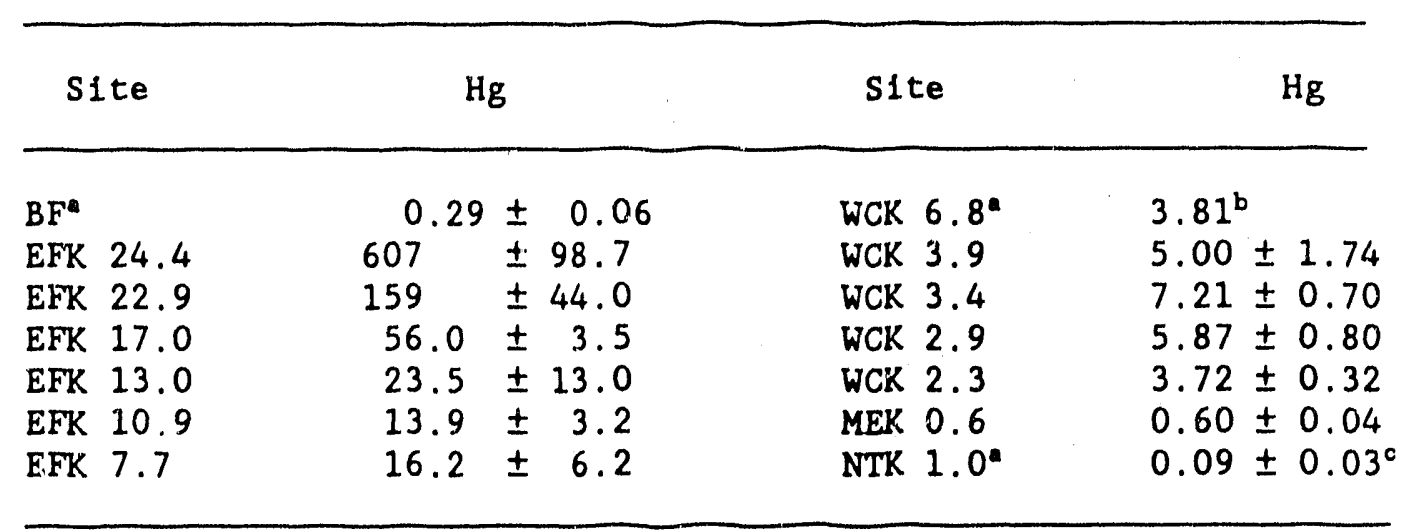

Denotes reference sites.

bonly one sample analyzed.

'Values near detection limit of analysis and may be an overestimate.

Notes: 1. Sediment in New Hope Pond contains about $150 \mathrm{ppm} \mathrm{Hg}$.

2. Sediment at EFK 22.9 contains approximately $60 \mathrm{ppm} \mathrm{Hg}$.

3 . $\mathrm{Hg}$ values may be correlated with the organic content and the age (turnover time) of the periphyton (e.g., greater concentrations at EFK 7.7 may reflect greater organic content or age of periphyton). 
APPENDIX G

CONCENTRATIONS OF INORGANIC COMPOUNDS (mg/L) IN COMPOSITE SAMPLES OF WATER COLLECTED AT THE OUTFALL OF NEW HOPE POND DURING 7-d TOXICITY TESTS AT NEW HOPE POND ON OCTOBER 7-14, NOVEMBER 4-11, AND NOVEMBER $18-25,1986$ 


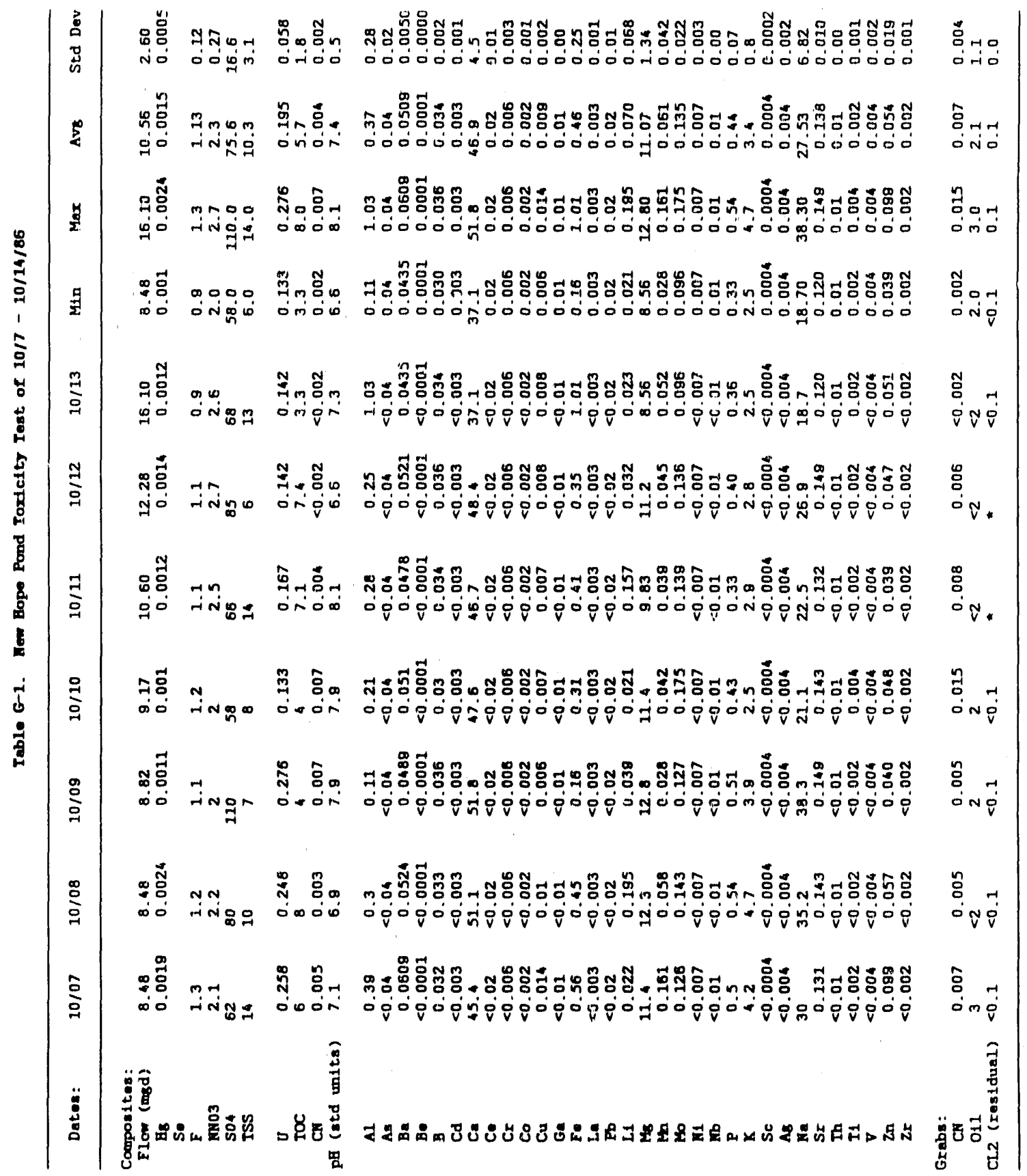




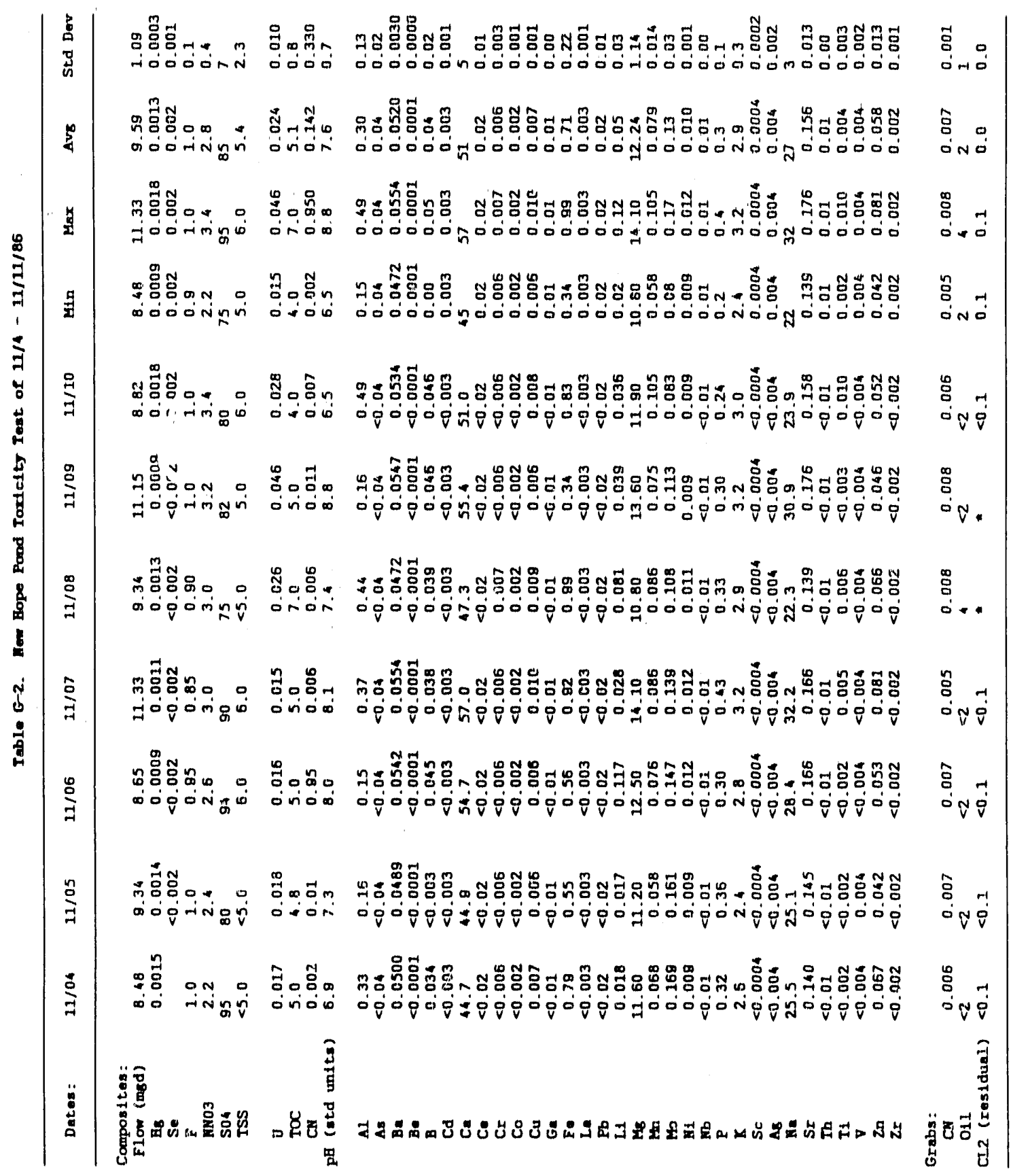




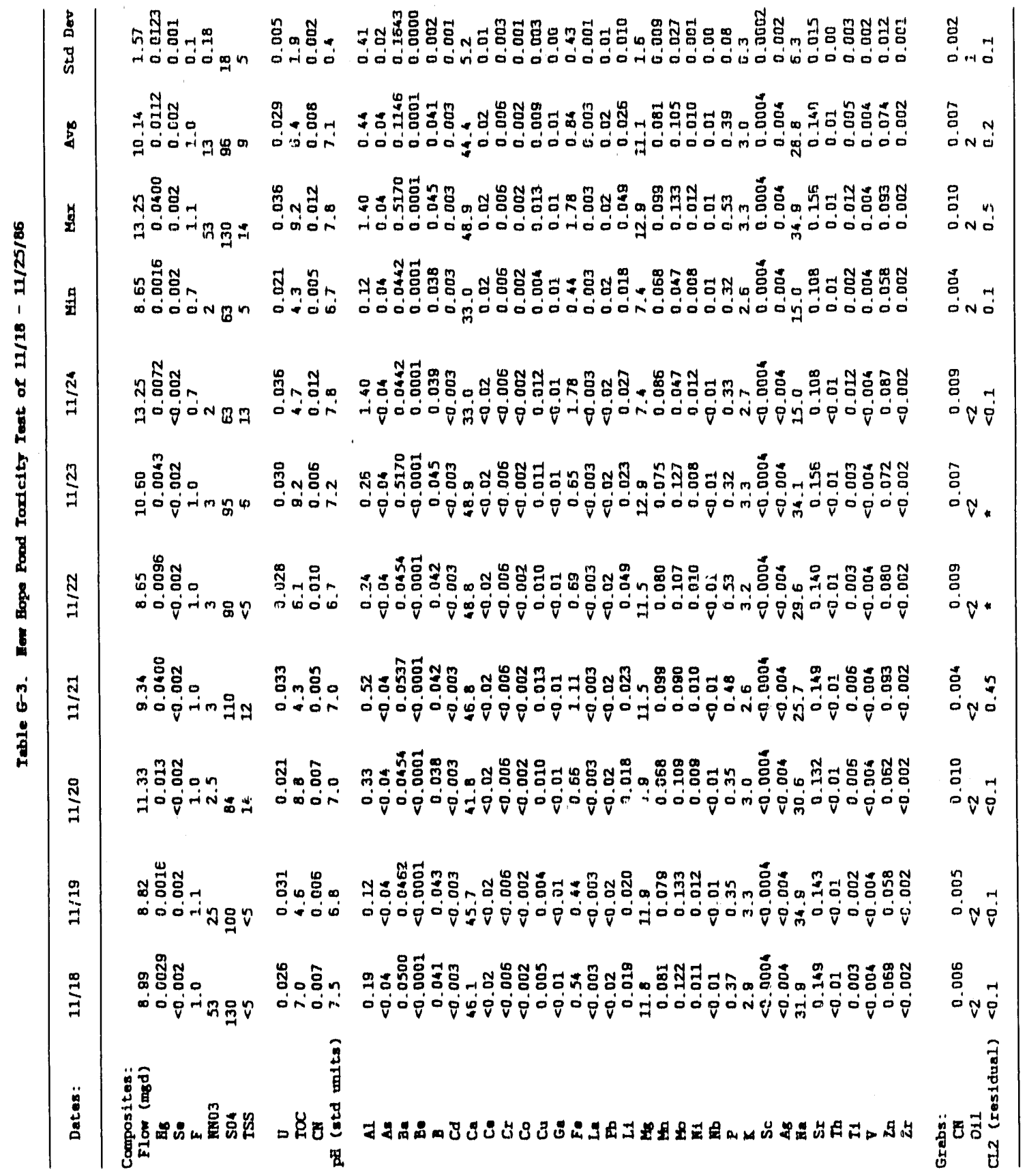




\section{APPENDIX H}

IIST OF INORGANIC CONSTITUENTS MEASURED DAILY IN COMPOSITE SAMPLES COLLECTED FROM THE INLET AND OUTLET OF NEW HOPE POND, OCTOBER 1 THROUGH DECEMBER 15, 1986 
Append1X H

\begin{tabular}{l} 
Determination \\
\hline \\
Flow \\
Mercury \\
Uranium, total \\
Biochemical oxygen demand \\
Chloride \\
Fluoride \\
Filterable residue \\
Butyl carbitol \\
Nitrates \\
Kjeldahi nitrogen
\end{tabular}

Determination

\section{Composites}

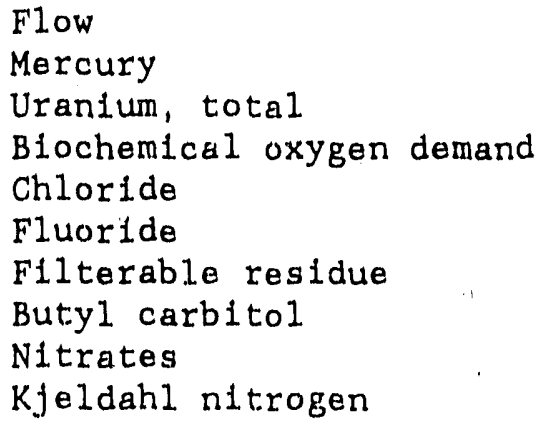

\section{ICP Sweep}

Aluminum
Barium
Boron
Calcium
Chromium
Copper
Iron
Lead
Magnesium
Molybdenum
Niobium
Potassium
Silver
Strontium
Vanadium
Zirconium

Aluminum

Barium

Boron

Chromium

Copper

Iron

Lead

Magnesium

Molybdenum

Potassium

Silver

Strontium

Zirconium

Grabs

Cyanide

Residual chlorine

Perchloroe thylene

Field Readings
$\mathrm{pH}$

Selenium

Ammonia

Chemfcal oxygen demand Cyanide

Total organic carbon

Sulfate

Total dissolved solids

Total nitrogen

\section{Arsenic}

Beryllium

Cadmium

Cerium

Cobalt

Gallium

Lanthium

Lithium

Manganese

Nicke 1

Phosphorus

Scandium

Sodium

Titanium

Zinc

011

Mercury

Settleable solids

Specific conductivity

Dissolved oxygen

Temperature 
APPENDIX I

CONCENTRATIONS OF INORGANIC COMPOUNDS (mg/L). IN COMPOSITE WATER COLLECTED AT THE OJTFALI OF NEW HOP 2 POND DURIMG JUNE 1 TO JULY 2 AND JULY 7 TO JULY 20, 1987 


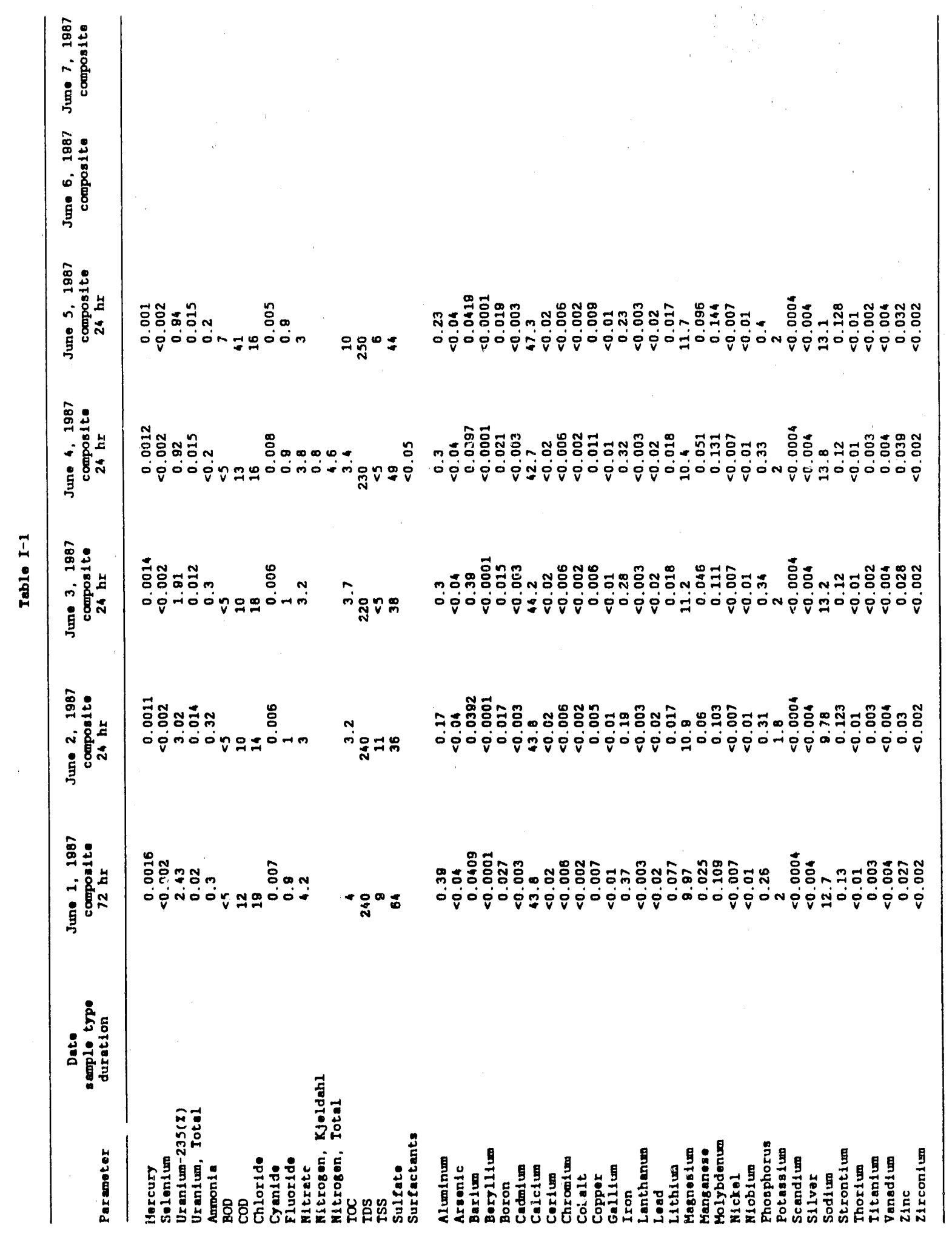




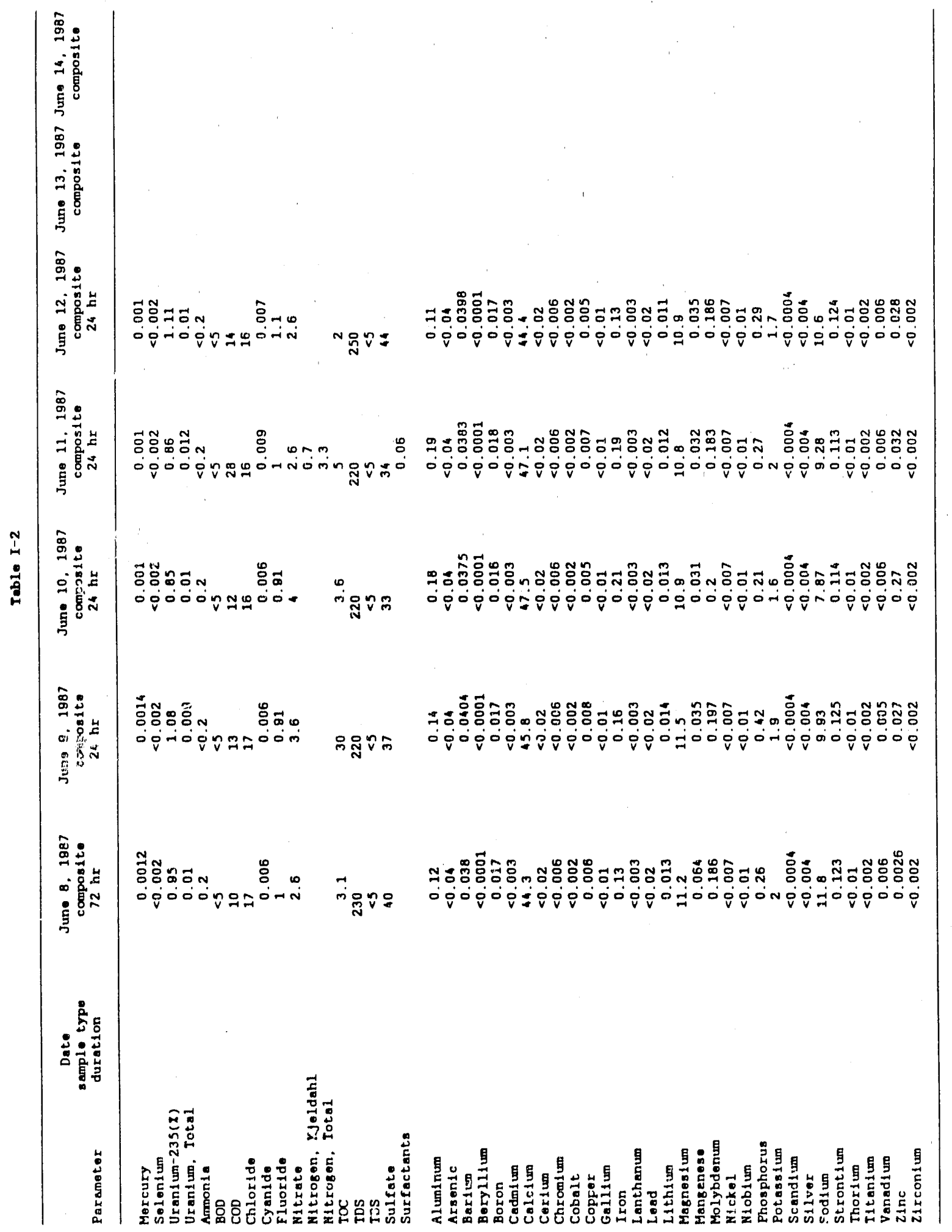




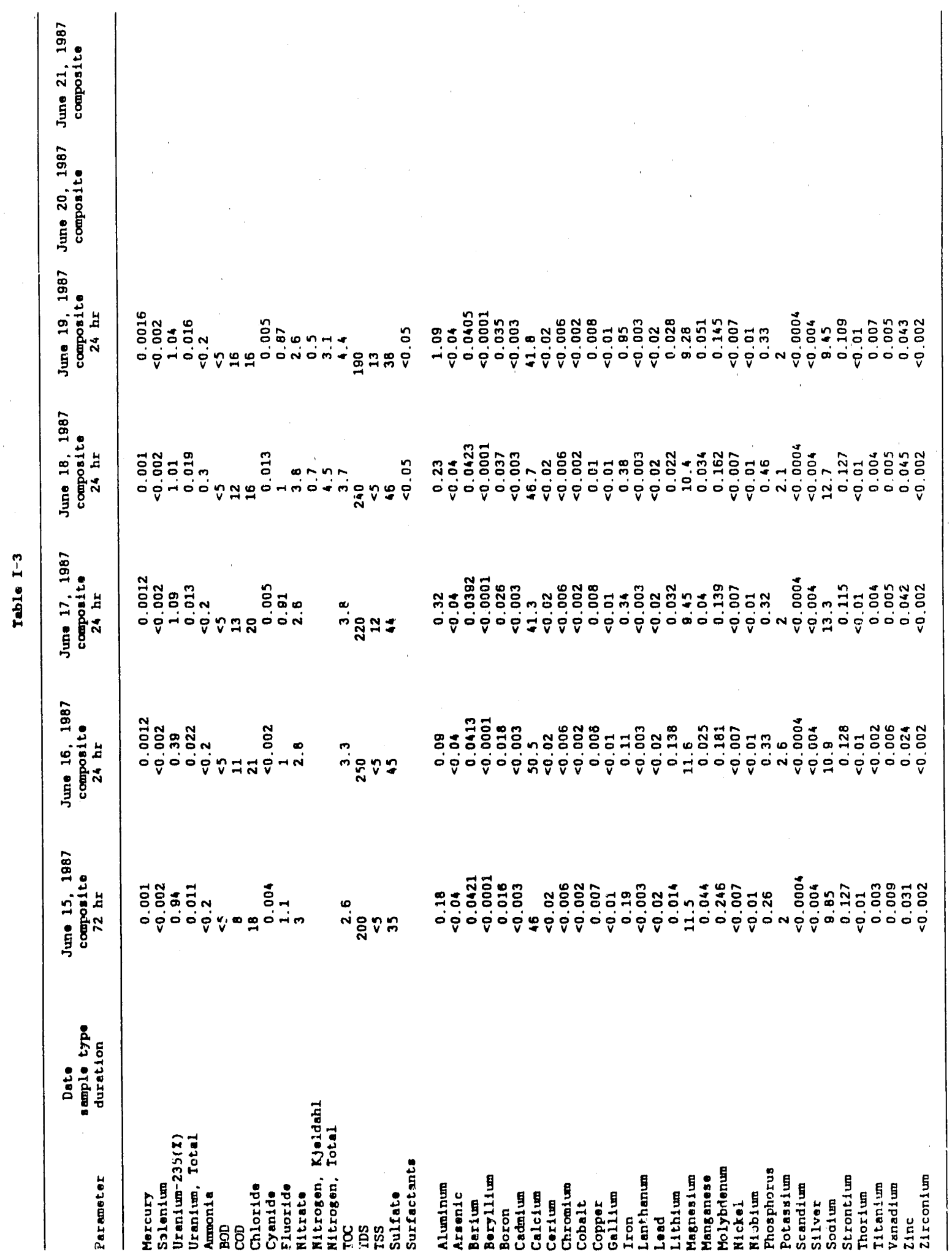




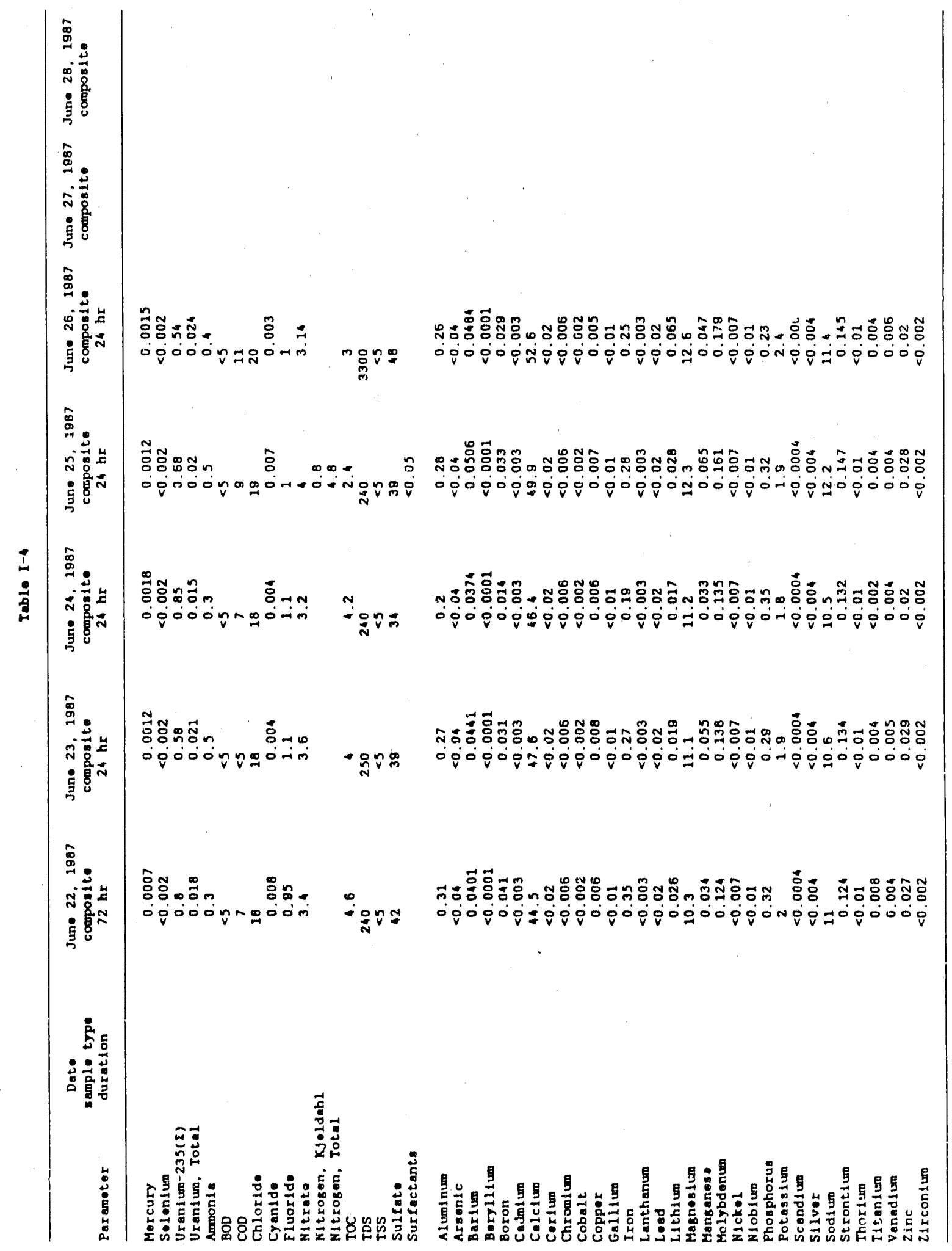




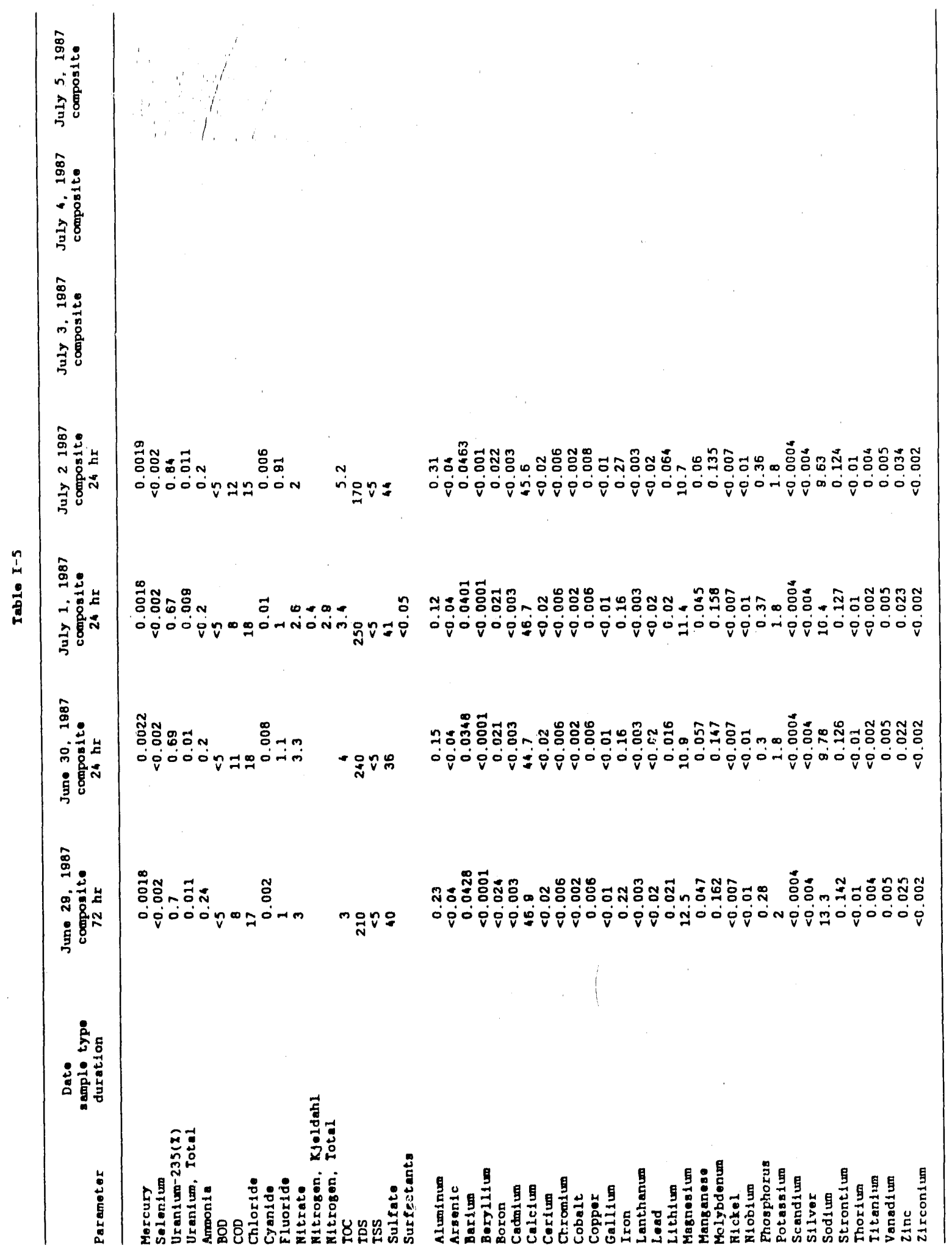




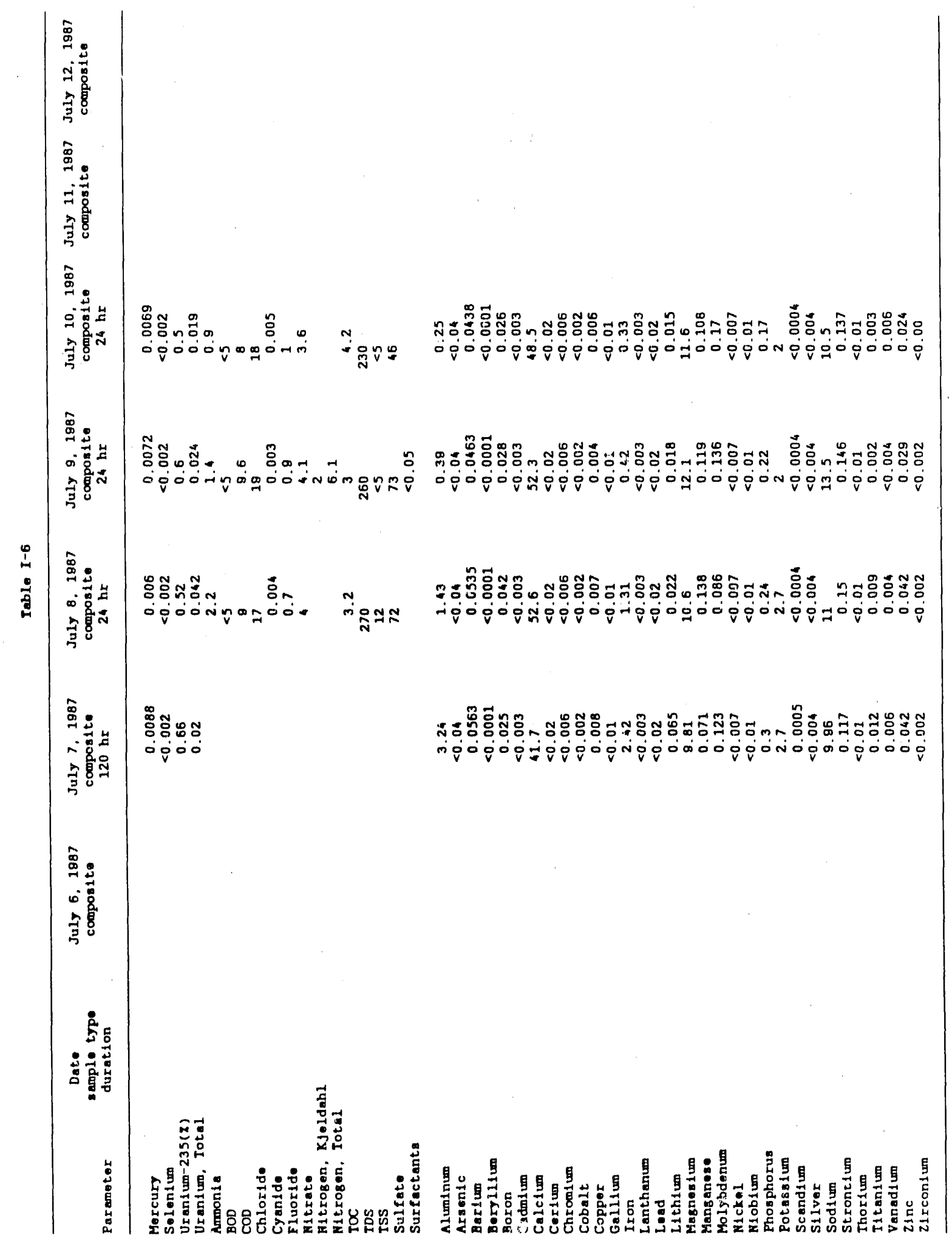




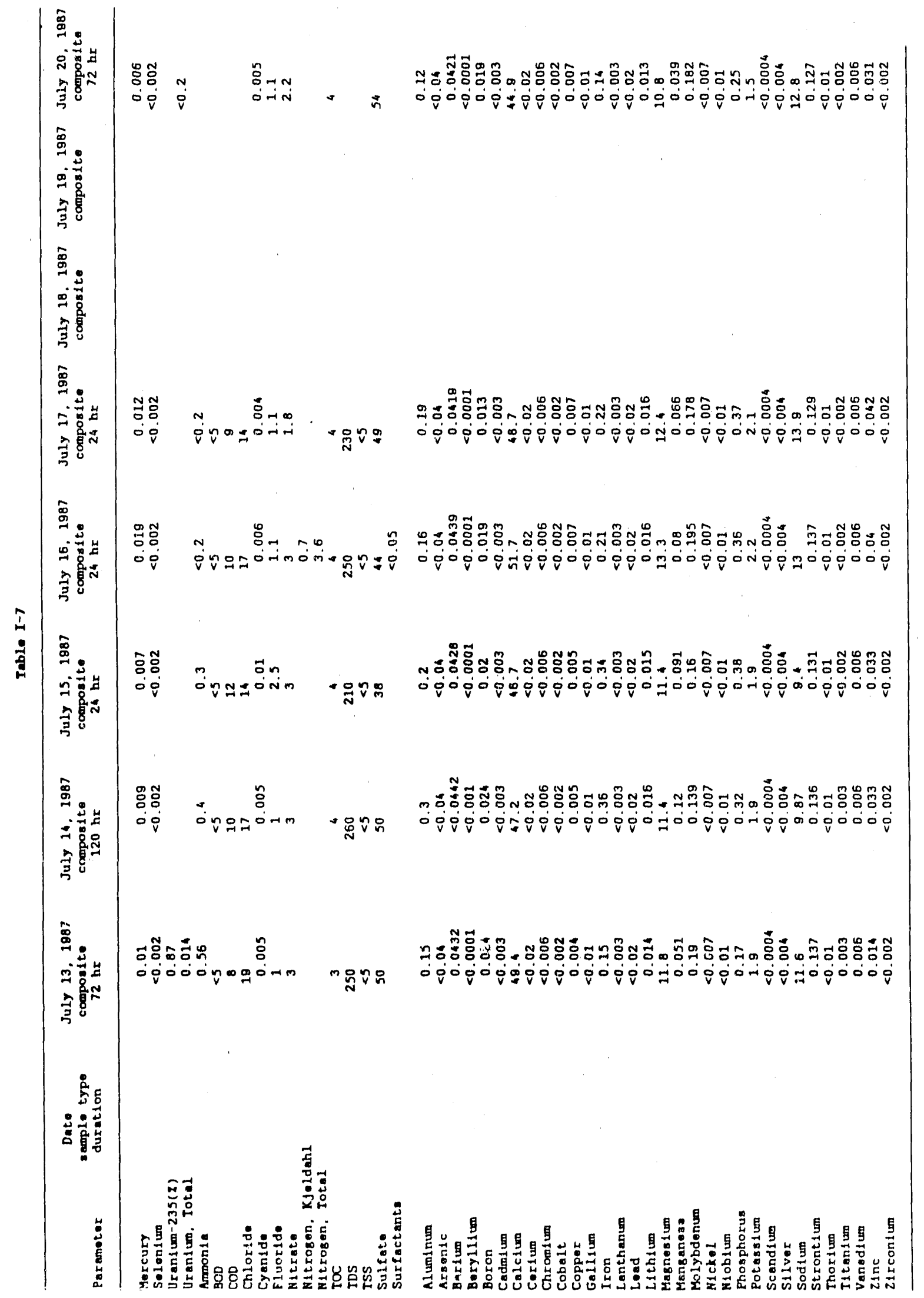




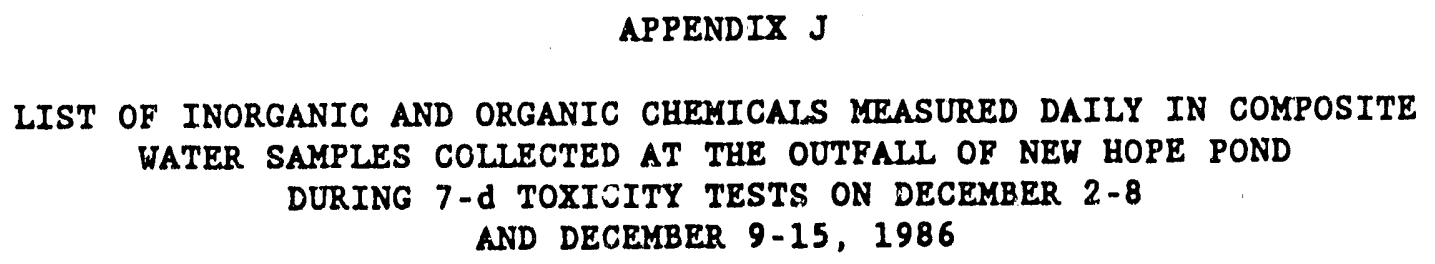


Appendix J

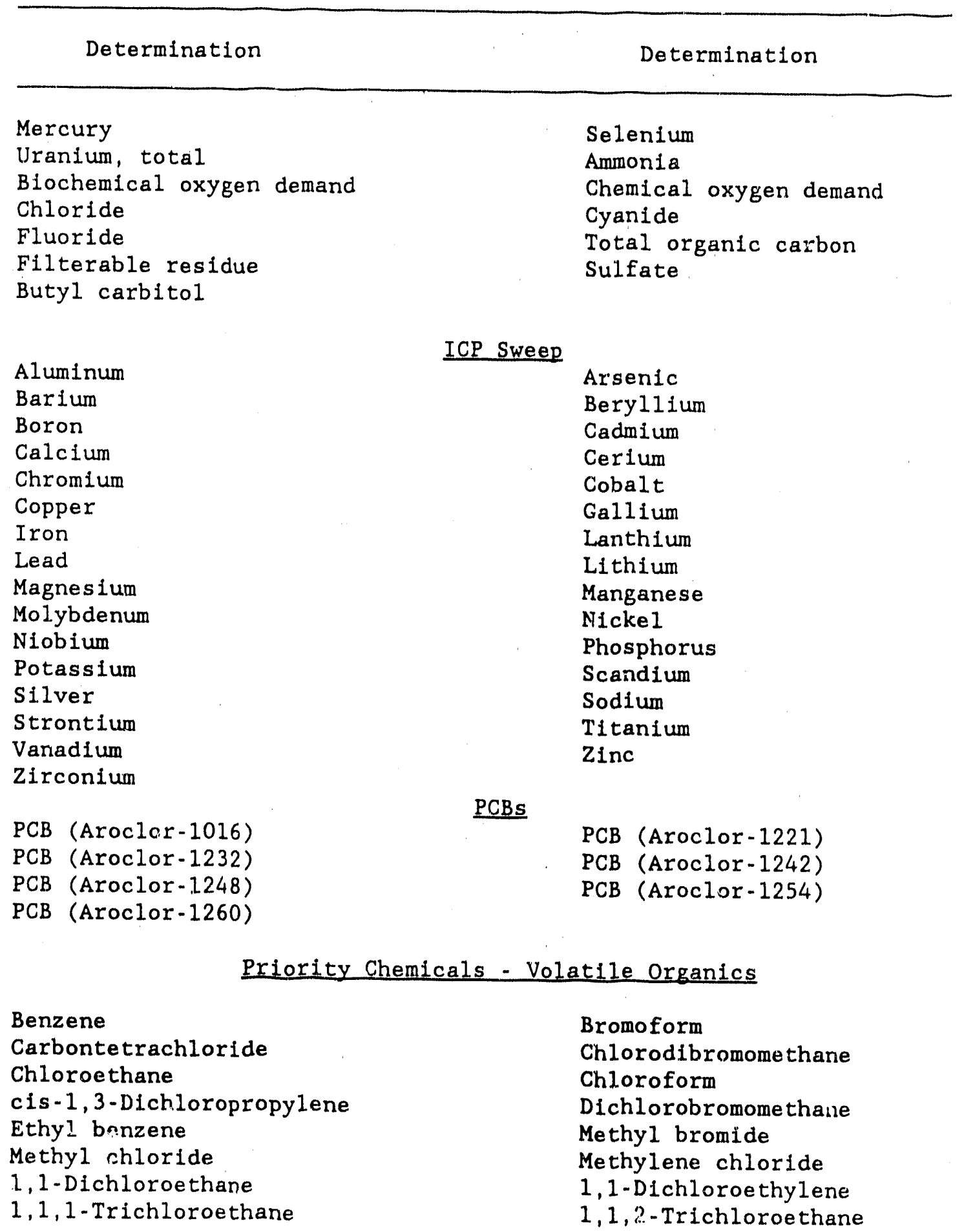


Appendix J, (continued)

Determination

1,1,2,2-Tetrachloroethane

1,2-Dichloroe thane

1,3-Dichlorobenzene

Tetrachloroe thylene (Perk)

trans-1,2-Dichloroe thylene

Trichloroe thylene

2-Chiloroethyl viny'l ether
Determination

1,2-Dichlorobenzene

1,2-Dichloropropane

1,4-Dichlorobenzene

Toluene

trans-1, 3-Dichlozopropylene

Trichlorofluorome thane

Vinyl chluride

\section{Priority Chemicals - Base Nelutrals}

bis - 2-Ethylhexylphthalate

Di-n-butylphthalate

Fluoranthene
Benzidine

Die thylphthalate

Phenanthrene

\section{Priority Chemicals - Acid Extraction}

Pheno1

4,6-Dinitro-o-cresol Pentachlorophenol

2-Nitro, henol

2,4-Dim. chylphenol

2,4,6-Trichloropheno1
4-Nitrophenol

p-Chloro-m-cresol

2-Chlorophenol

2,4-Dich1orophenol

2,4-Dinitrophenol 
APPENDIX $\mathrm{K}$

LIST OF ORGANIC CHEMICALS MEASURED IN DA:LYY COMPOSITE WAIER SAMPLES COLLECTED AT THE OUTRALL OR NEW YOPE POND DURING 7-d TOXICITY TESTS ON OCTOBER 7-14, NCIVEMBER 3-11, AND NOVEMBER 18-25, 1986 


\begin{tabular}{|c|c|}
\hline Compounds & Compounds \\
\hline $\begin{array}{l}\text { Dibromomethane } \\
\text { Butyl carbitol } \\
\text { Chloromethane } \\
\text { Vinyl chloride } \\
\text { Methylene chloride } \\
\text { Carbon disulfide } \\
\text { 1,1-Dichloroethane } \\
\text { Chloroform } \\
\text { 2-Butanone } \\
\text { Carbon tetrachloride } \\
\text { Bromodichloromethane } \\
\text { cis-1,3-Dichloropropene } \\
\text { Dibromochloroinethane } \\
\text { Benzene } \\
\text { 2-Chloroethylvinylether } \\
\text { 4-Methyl-2-pentanone } \\
\text { Tetrachloroethene } \\
\text { Toluene } \\
\text { Ethylbenzene } \\
\text { Total xylenes } \\
\text { bis(2-Chloroethyl)ether } \\
\text { 1,3-Dichlorobenzene } \\
\text { Benzyl alcohol } \\
\text { 2-Methylphenol } \\
\text { 4-Methylphenol } \\
\text { Hexachloroethane } \\
\text { Isophorone } \\
\text { 2,4-Dimethylphenol } \\
\text { bis (2-Chloroethoxy)methane } \\
\text { 1,2,4-Trichlorobenzene } \\
\text { 4-Nitroaniline } \\
\text { 4-Chloro-3-methylphenol } \\
\text { Hexachlorocyclopentadiene } \\
\text { 2,4,5-Trichlorophenol } \\
\text { 2-Nitroanlline } \\
\text { Acenaphthylene } \\
\text { Acenaphthene } \\
\text { 4-Nitrophenol } \\
\text { 2,4-Dinltrotoluene } \\
\text { Diethylphthalate } \\
\text { - }\end{array}$ & 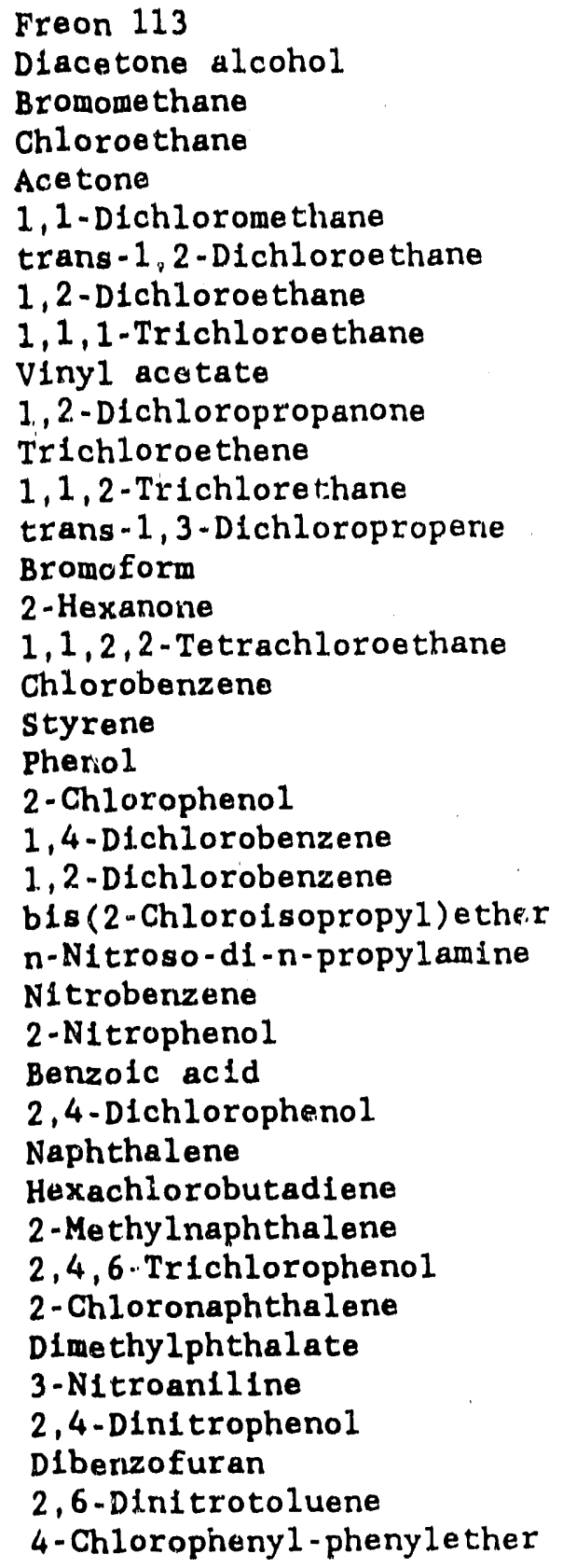 \\
\hline
\end{tabular}


Append IX K, (continued)

\begin{tabular}{|c|c|}
\hline Compounds & Compounds \\
\hline $\begin{array}{l}\text { Fluorene } \\
\text { 4,6-Dinitro-2-methylphenol } \\
\text { 4-Bromophenyl-phenylether } \\
\text { Pentachlorophenol } \\
\text { Anthracene } \\
\text { Fluoranthrene } \\
\text { Butylbenzylphthalate } \\
\text { Benzo(a)anthracene } \\
\text { Chrysene } \\
\text { Benzo(b) fluoranthene } \\
\text { Benzo(a)pyrene } \\
\text { D1benzo(a,h)anthracene } \\
\text { PCB (AIoclor-1016) } \\
\text { PCB (Al sclor -1232) } \\
\text { PCB (Aroclor -1248) } \\
\text { PCB (Aroclor-1260) }\end{array}$ & $\begin{array}{l}\text { 4-Nitroaniline } \\
\text { n-Nitrosodiphenylamlne } \\
\text { Hexachlorobenzene } \\
\text { Pheranthrene } \\
\text { Di-n-butylphthalate } \\
\text { Pyrene } \\
3,3^{\prime} \text {-Dichlorobenzidine } \\
\text { bis(2-Ethylhexyl) phthalate } \\
\text { Di-n-octylphthalate } \\
\text { Benzo(k)fluoranthene } \\
\text { Indeno }(1,2,3 \text {-cd)pyrene } \\
\text { Benzo }(g, h, 1) \text { perylene } \\
\text { PCB (Aroclor-1221) } \\
\text { PCB (Aroclor-1242) } \\
\text { PCB (Aroclor-1254) }\end{array}$ \\
\hline
\end{tabular}


Appendix I

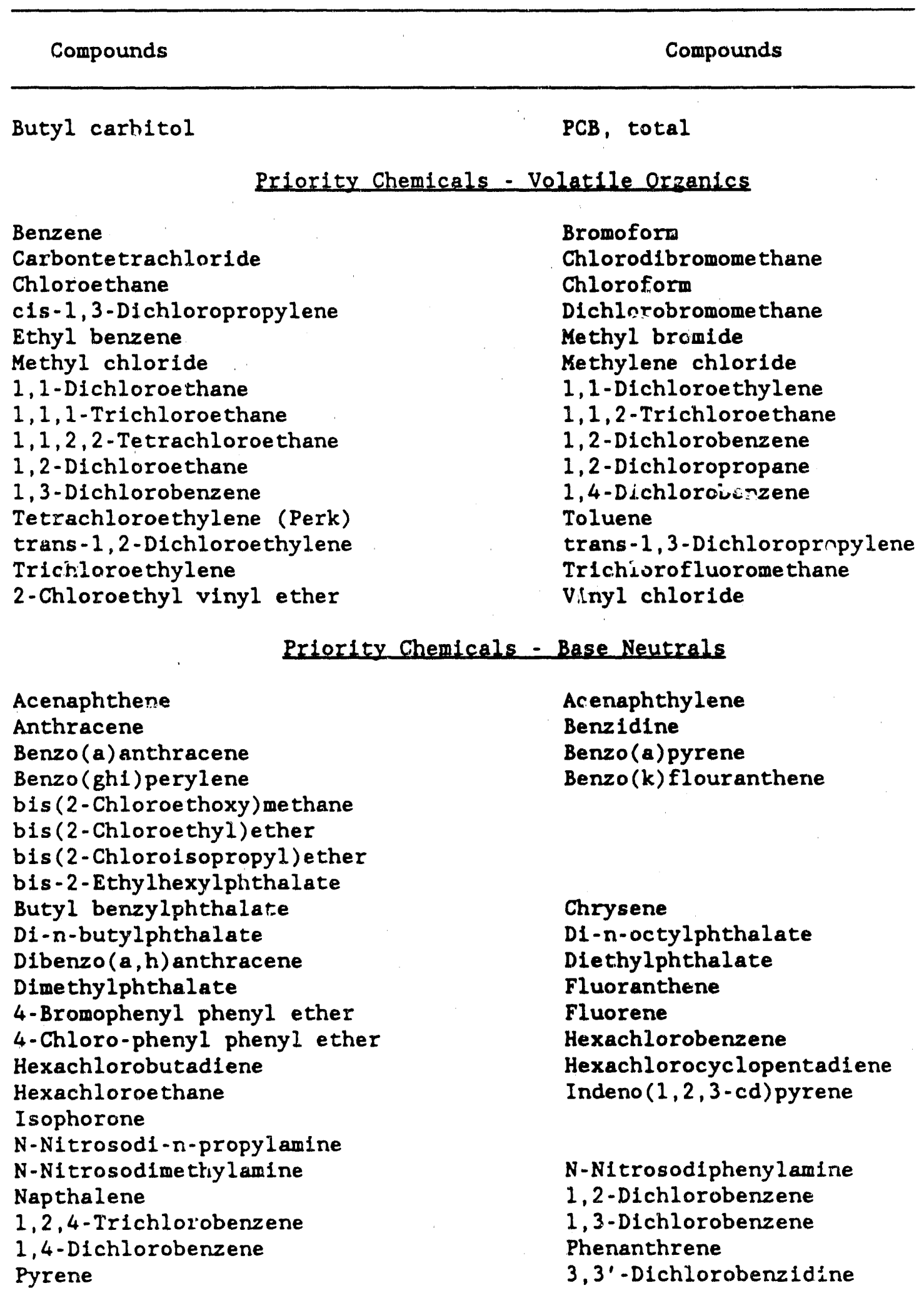




$$
\text { L-4 }
$$

Appendix L. (continued)

\begin{tabular}{|c|c|}
\hline Compounds & Compounds \\
\hline $\begin{array}{l}\text { 3,4-Benzofluoranthene } \\
\text { 2,4-Dinitrotoluene }\end{array}$ & $\begin{array}{l}\text { 2-Chloronaphthalene } \\
2,6 \text {-Dinitrotoluene }\end{array}$ \\
\hline \multicolumn{2}{|c|}{ Priority Chemicals - Acid Extraction } \\
\hline $\begin{array}{l}\text { Phenol } \\
\text { 4,6-Dinitro-o-cresol } \\
\text { Pentachlorophenol } \\
\text { 2-Nitrophenol } \\
\text { 2,4-Dimethylphenol } \\
\text { 2,4,6-Trichlorophenol }\end{array}$ & $\begin{array}{l}\text { 4-Nitrophenol } \\
\text { p-Chloro-m-cresol } \\
\text { 2-Chlorophenol } \\
\text { 2,4-Dichlorophenol } \\
\text { 2,4-Dinitrophenol }\end{array}$ \\
\hline
\end{tabular}



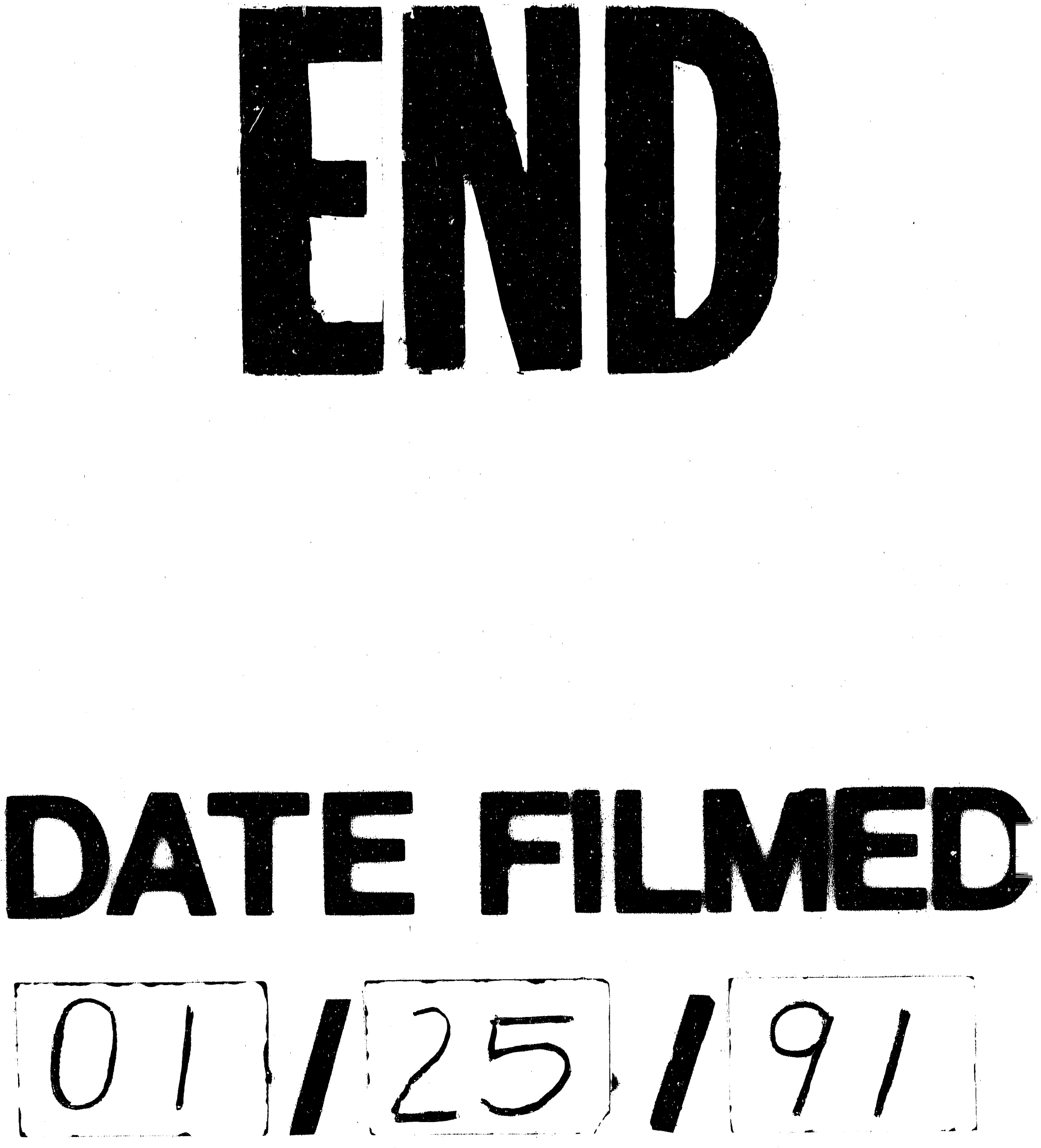
